\title{
BIOLOGIA, MANEJO E CARACTERIZAÇÃO BIOQUÍMICA E GENÉTICA DE BIOTIPOS DE PLANTAS DANINHAS RESISTENTES AOS HERBICIDAS INIBIDORES DA ACETOLACTATO SINTASE (ALS)
}

\section{PATRÍCIA ANDREA MONQUEIRO}

Engenheira Agrônoma

Orientador: Prof. Dr. Pedro Jacob Christoffoleti

\begin{abstract}
Dissertação apresentada à Escola Superior de Agricultura "Luiz de Queiroz", Universidade de São Paulo, para obtenção do título de Mestre em Agronomia, Área de Concentração:

Fitotecnia
\end{abstract}

PIRACICABA

Estado de São Paulo

Outubro - 1999 


\section{ERRATA}

\begin{tabular}{|c|c|c|}
\hline Página & Onde se lê: & Leia-se: \\
\hline XVI & ... creatina através ... & ... creatina. Através ... \\
\hline XIX & $\ldots$ whete $\ldots$ & ... where ... \\
\hline 4 & $\begin{array}{l}\text {... biotipos de plantas daninhas. } \\
\text { distribuídos em } 145 \text { espécies ... }\end{array}$ & $\begin{array}{l}\text {... biotipos de plantas daninhas } \\
\text { resistentes, distribuídos em } 145 \\
\text { espécies (Heap, 1999) }\end{array}$ \\
\hline 6 & ... Christoffoleti et al. (1996) ... & ... Christoffoleti et al. (1997) ... \\
\hline 11 & ... Kissmann (1992) ... & ... Kissmann \& Groth (1992) ... \\
\hline 12 & ... Sanchez et al. (1997) ... & ... Sanchez \& Zandonade (1997) ... \\
\hline 12 & ... Tamashiro et al. (1978) ... & ... Tamashiro \& Leitão Filho (1978) \\
\hline $15 \approx 62$ & $\mathbf{G R}_{\mathbf{5 0}}$ & $e^{-G R 50 / b}$ \\
\hline 18 & ... enzima ALS ... & ... ALS ... \\
\hline 32 & $\mathrm{pc} \mathrm{ml} / \mathrm{g} / 100 \mathrm{ml}$ & p.c. $\mathrm{mL}$ ou $\mathrm{g} / 100 \mathrm{~mL}$ \\
\hline 34 & $10.000 \mathrm{~g}$ & $10.000 \mathrm{~g}$ \\
\hline 34 & $500 \mu$ & $500 \mu \mathrm{L}$ \\
\hline 35 & Nicotiana tabacccum & Nicotiana tabaccum \\
\hline 39,42 a 45 & D.M.S. $(\%)$ & D.M.S. \\
\hline 53 & Reação Colorida & Coloração \\
\hline 54 & Clycine max & Glycine $\max$ \\
\hline 61 & $\%$ Controle Visual & Biomassa verde \\
\hline 73 & P1-P6 & P1-P4 \\
\hline 86 & $\ldots$ da ALS indicam que ... & $\begin{array}{l}\text {... da ALS não permitem concluir } \\
\text { que ... }\end{array}$ \\
\hline
\end{tabular}


Dados Internacionais de Catalogaçāo na Publicaçāo (CIP) DIVISĀO DE BIBLIOTECA E DOCUMENTAÇĀO - Campus "Luiz de Queiroz"/USP

Monqueiro, Patricia Andrea

Biologia, manejo e caracterização bioquimica e genética de biotipos de plantas daninhas resistentes aos herbicidas inibidores da acetolactato sintase (ALS)

$97 \mathrm{p}$.

Dissertação (mestrado) - Escola Superior de Agricultura Luiz de Queiroz, 1999. Bibliografia.

1. Bioquímica vegetal 2. Genética vegetal 3. Herbicida 4. Inibidor de enzima 5. Planta daninha 6. Resistência ao herbicida I.Título

CDD 632.58 


\section{AGRADECIMENTOS}

Agradeço profundamente a todos que, de forma direta ou indiretamente colaboraram na conclusão deste trabalho.

Aos meus pais, Nelson Monqueiro e Maria Helena Monqueiro e ao meu irmão Marcos Monqueiro, que sempre me apoiaram em todos os momentos.

Ao Professor Dr. Pedro Jacob Christoffoleti, do Departamento de Produção Vegetal da ESALQ/USP, pela orientação e amizade que me acompanha durante minha vida acadêmica.

À Eng $=$ Agr- Marluce G. Cortez, pela amizade, compreensão e todos os momentos de descontração e paz.

Ao Professor Dr. Carlos Tadeu dos Santos Dias, do Departamento de Ciências Exatas da ESALQ/USP, pela paciência e auxílio na análise estatística.

À Professora Helaine Carrer, do Centro de Biotecnologia Agrícola da ESALQ/USP, pelos ensinamentos na área de biologia molecular.

Aos funcionários e amigos do Departamento de Produção Vegetal, em especial a Luiz Ferrari, Ony Rodrigues de Campos, Aparecido Mendes, Elisabete Ap. Sarkis São João e Silvia Borghesi.

Aos meus amigos que sempre me apoiaram e me deram força: Liesellote G. Dechant, Juliana Kiomi Takimoto, Denise Mezza, Silvia Maymi Fugiwara, e todos as moradoras da República Cupido.

Aos meus amigos e professores Maria Clara Pestana, Tercílio Calza Júnior e Irving Berenger.

À FAPESP, que me deu suporte financeiro, sem o qual, a elaboração deste trabalho seria comprometida. 


\section{SUMÁRIO}

Página

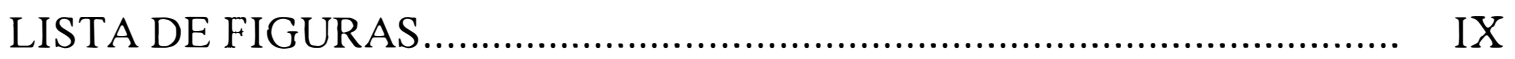

LISTA DE TABELAS.................................................................... XIII

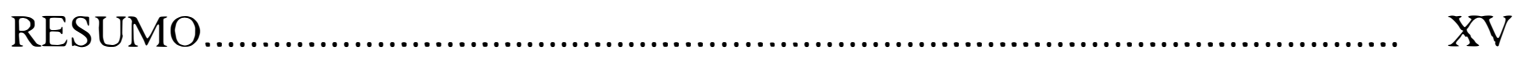

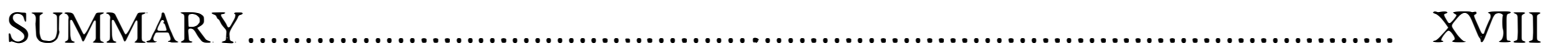

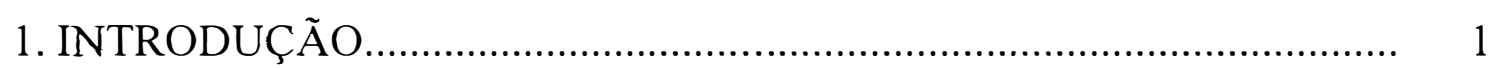

2. REVISÃO DA LITERATURA............................................................... 3

2.1. Resistência de Plantas Daninhas aos Herbicidas.................................... 3

2.2. Resistência das Plantas Daninhas aos Herbicidas Inibidores da

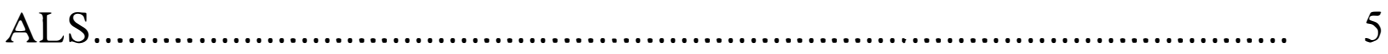

2.3. As Plantas Daninhas Amaranthus quitensis, Bidens pilosa e Bidens

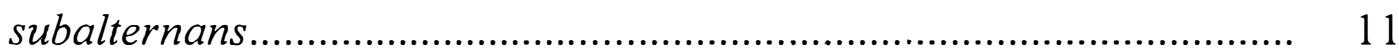

2.3.1. Amaranthus quitensis.................................................................... 11

2.3.2. Bidens pilosa e Bidens subalternans................................................ 12

2.4. Manejo da Resistência...................................................................... 13

2.5. Modelos Estatísticos de Análise de Resultados Experimentais.............. 14

2.5.1. Estabelecimento de Curvas de Dose-Resposta.................................... 14

2.5.2. Análise de Crescimento................................................................ 16

3. MATERIAL E MÉTODOS............................................................. 18

3.1. Avaliação da sensibilidade de biotipos de Bidens pilosa/Bidens sulbalternans aos herbicidas inibidores da ALS e a herbicidas com outros mecanismos de ação (herbicidas alternativos) em condições de

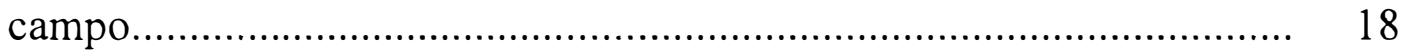

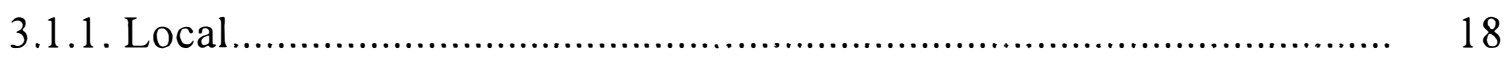

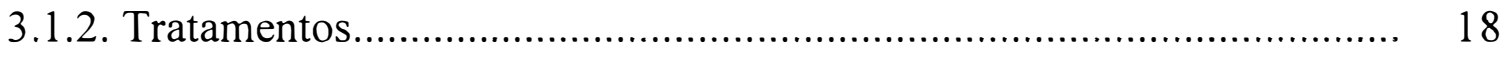

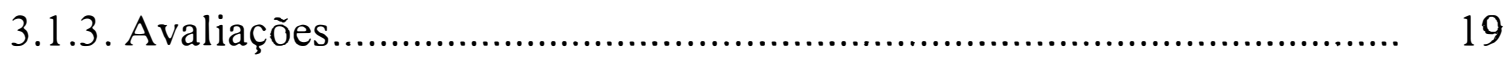


3.1.4. Análise dos dados

3.2. Determinação da resistência cruzada e curvas de dose-resposta de populações resistentes (R) e suscetíveis (S) de Bidens pilosa/Bidens subalternans e Amaranthus quitensis aos herbicidas inibidores da ALS

3.2.1. Local

3.2.2. Material Vegetal........................................................................ 21

3.2.3. Tratamentos utilizados............................................................... 22

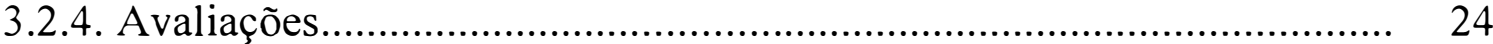

3.2.5. Análise dos dados...................................................................... 24

3.3. Teste com diferentes herbicidas para manejo de populações $\mathrm{R}$ de Bidens pilosa/Bidens subalternans e Amaranthus quitensis aos herbicidas inibidores da ALS em condições de casa-de-vegetação........

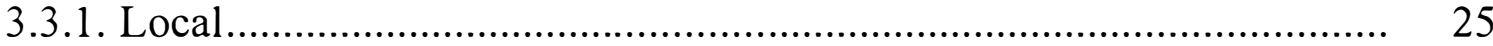

3.3.2. Semeadura e obtenção das plantas..................................................... 25

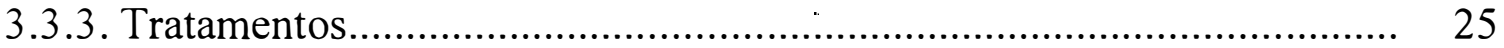

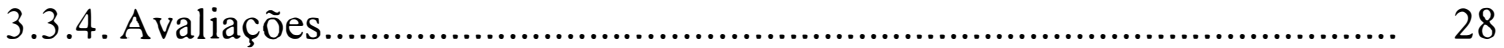

3.3.5. Análise dos dados................................................................... 28

3.4. Análise de crescimento comparativa entre biotipos $\mathrm{R}$ e $\mathrm{S}$ de Bidens pilosa/Bidens sulbalternans e Amaranthus quitensis........................... 28

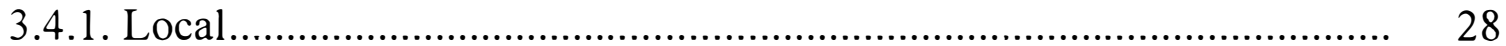

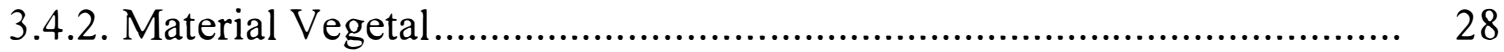

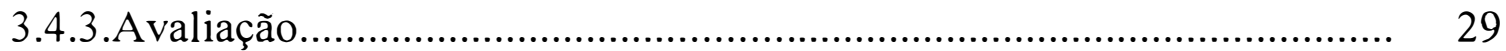

3.4.4. Análise dos Dados.......................................................................... 29

3.5. Teste rápido da sensibilidade da ALS dos biotipos $\mathrm{R}$ e $\mathrm{S}$ de Bidens pilosa/Bidens subalternans e Amaranthus quitensis através de bioensaio 


\section{Página}

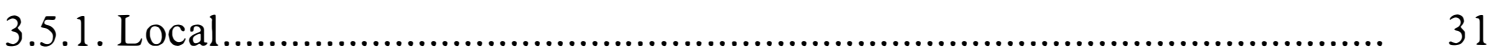

3.5.2. Material Vegetal........................................................................ 31

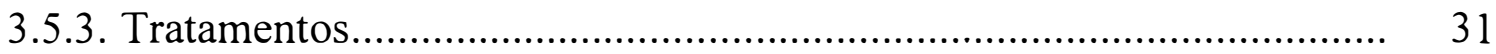

3.5.4. Ensaio com a enzima ALS........................................................... 33

3.6. Sequenciamento da região de domínio $\mathrm{A}$ do gene que confere resistência aos herbicidas inibidores da ALS em Amaranthus

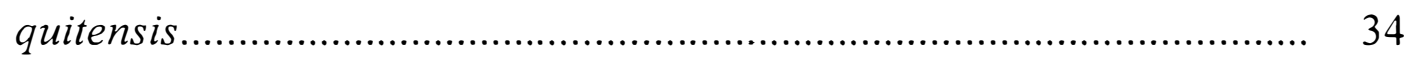

3.6.1. Material Vegetal........................................................................ 34

3.6.2. Isolamento de DNA total............................................................ 34

3.6.3. Amplificação de fragmento do gene ALS............................................ 35

3.6.4. Eletroforese do PCR..................................................................... 36

3.6.5. Clonagem de fragmento de PCR em vetor pUC 18 (Sure Clone)....... 36

4. RESULTADOS E DISCUSSÕES........................................................ 38

4.1. Avaliação da sensibilidade de biotipos resistentes de Bidens pilosa/Bidens subalternans aos herbicidas inibidores da ALS e a herbicidas com outros mecanismos de ação (alternativos) em condições de campo........................................................................ 38

4.2. Teste com diferentes herbicidas para manejo de populações $\mathrm{R}$ de Bidens pilosa/Bidens subalternans e Amaranthus quitensis aos herbicidas inibidores da ALS em condições de casa-de-vegetação.......

4.3. Análise de crescimento comparativa entre biotipos $\mathrm{R}$ e $\mathrm{S}$ de Bidens pilosa/Bidens subalternans e Amaranthus quitensis.

4.4. Teste rápido da sensibilidade da ALS das plantas R e $\mathrm{S}$ de Bidens pilosa/Bidens subalternans Amaranthus quitensis através de bioensaio. 


\section{Página}

4.5. Determinação da resistência cruzada e curvas de dose-resposta de populações resistentes (R) e suscetíveis (S) de Bidens pilosa/Bidens subalternans e Amaranthus quitensis aos herbicidas inibidores da ALS.

4.6. Sequenciamento da região de domínio A do gene que confere resistência aos herbicidas inibidores da ALS em Amaranthus quitensis.

4.6.1 Amplificação do gen codifica a enzima ALS...................................... 72

4.6.2. Sequenciamento de DNA................................................................ 73

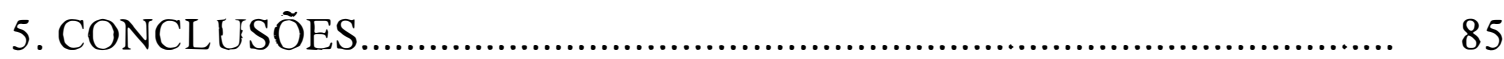

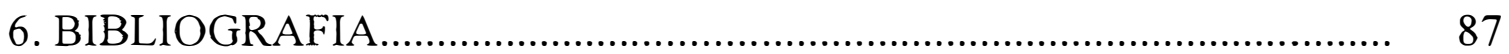




\section{LISTA DE FIGURAS}

Página

Figura I Curvas de produção de biomassa verde pelos biotipos resistentes e suscetíveis de B. pilosa/B. subalternans...................

Figura 2 Curvas de produção de biomassa seca pelos biotipos resistentes e suscetíveis de B. pilosa/B.subalternans.

Figura 3 Área foliar dos biotipos resistentes e suscetíveis de B. pilosa/B. subalternans......

Figura 4 Curvas de produção de biomassa verde pelos biotipos resistentes e suscetíveis de $A$. quitensis.

Figura 5 Curvas de produção de biomassa seca pelos biotipos resistentes e suscetíveis de $A$. quitensis....................................................... 51

Figura 6 Área foliar dos biotipos resistentes e suscetíveis de A. quitensis. 51

Figura 7 Curvas de dose-resposta da porcentagem de controle dos biotipos resistentes e suscetíveis de B. pilosa/B. subalternans aos 7 DAT com chlorimuron - ethyl, segundo o modelo loglogístico

Figura 8 Curvas de dose-resposta da porcentagem de controle dos biotipos resistentes e suscetíveis de B. pilosa/B. subalternans aos 14 DAT com chlorimuron - ethyl, segundo o modelo loglogístico.

Figura 9 Curvas de dose-resposta da porcentagem de controle dos biotipos resistentes e suscetíveis de B. pilosa/B. subalternans aos 7 DAT com nicosulfuron, segundo o modelo log-logístico... 56

Figura 10 Curvas de dose-resposta da porcentagem de controle dos biotipos resistentes e suscetíveis de B. pilosa/B. subalternans aos 14 DAT com nicosulfuron, segundo o modelo log-logístico. 56 
Página

Figura 11 Curvas de dose-resposta da porcentagem de controle dos biotipos resistentes e suscetíveis de B. pilosa/B. subalternans aos 7 DAT com imazethapyr, segundo o modelo log-logístico... 57

Figura 12 Curvas de dose-resposta da porcentagem de controle dos biotipos resistentes e suscetíveis de B. pilosa/B. subalternans aos 14 DAT com imazethapyr, segundo o modelo log-logístico. 57

Figura 13 Curvas de dose-resposta da produção de biomassa verde pelos biotipos resistentes e suscetíveis de B. pilosa/B. subalternans, após tratamento com chlorimuron-ethyl, segundo o modelo loglogístico

Figura 14 Curvas de dose-resposta da produção de biomassa seca pelos biotipos resistentes e suscetiveis de B. pilosa/B. subalternans, após tratamento com chlorimuron-ethyl, segundo o modelo loglogístico.

Figura 15 Curvas de dose-resposta da produção de biomassa verde pelos biotipos resistentes e suscetiveis de B. pilosa/B. subalternans, após tratamento com nicosulfuron, segundo o modelo loglogístico

Figura 16 Curvas de dose-resposta da produção de biomassa seca pelos biotipos resistentes e suscetiveis de B. pilosa/B. Subalternans, após tratamento com nicosulfuron, segundo o modelo loglogístico.

Figura 17 Curvas de dose-resposta da produção de biomassa verde Pelos biotipos resistentes e suscetíveis de B. pilosa/B. subalternans, após tratamento com imazethapyr, segundo o modelo loglogístico. 
Página

Figura 18 Curvas de dose-resposta da produção de biomassa seca pelos biotipos resistentes e suscetíveis de B. pilosa/B. subalternans, após tratamento com imazethapyr, segundo o modelo loglogístico

Figura 19 Curvas de dose-resposta da porcentagem de controle dos biotipos resistentes e suscetíveis de $A$. quitensis aos 7 DAT com chlorimuron-ethyl, segundo modelo hiperbólico

Figura 20 Curvas de dose-resposta da porcentagem de controle dos biotipos resistentes e suscetíveis de $A$. quitensis aos 14 DAT com chlorimuron-ethyl, segundo o modelo hiperbólico

Figura 21 Curvas de dose-resposta da porcentagem de controle dos biotipos resistentes e suscetíveis de $A$. quitensis aos 7 DAT com nicosulfuron, segund o o modelo hiperbólico.

Figura 22 Curvas de dose-resposta da porcentagem de controle dos biotipos resistentes e suscetíveis de $A$. quitensis aos 14 DAT com nicosulfuron

Figura 23 Curvas de dose-resposta da porcentagem de controle dos biotipos resistentes e suscetíveis de $A$. quitensis aos 7 DAT com imazethapyr, segundo o modelo hiperbólico.........................

Figura 24 Curvas de dose-resposta da porcentagem de controle dos biotipos resistentes e suscetíveis de $A$. quitensis aos 14 DAT com imazethapyr, segundo modelo hiperbólico

Figura 25 Curvas de dose-resposta da produção de biomassa verde pelos biotipos resistentes e suscetíveis de A. quitensis, após tratamento com chlorimuron-ethyl, segundo o modelo exponencial 
Página

Figura 26 Curvas de dose-resposta da produção de biomassa seca pelos biotipos resistentes e suscetíveis de A. quitensis, após tratamento com chlorimuron-ethyl, segundo o modelo exponencial........................................................................

Figura 27 Curvas de dose-resposta da produção de biomassa verde pelos biotipos resistentes e suscetíveis de A. quitensis, após tratamento com nicosulfuron, segundo modelo exponencial....... 70

Figura 28 Curvas de dose-resposta da produção de biomassa seca pelos biotipos resistentes e suscetíveis de A. quitensis, após tratamento com nicosulfuron, segundo modelo exponencial........

Figura 29 Curvas de dose-resposta da produção de biomassa verde pelos biotipos resistentes e suscetíveis de A. quitensis, após tratamento com imazethapyr, segundo modelo exponencial........

Figura 30 Curvas de dose-resposta da produção de biomassa seca pelos biotipos resistentes e suscetíveis de A. quitensis, após tratamento com imazethapyr, segundo modelo exponencial......... 


\section{LISTA DE TABELAS}

Página

Tabela 1 Descrição dos tratamentos utilizados no experimento instalado no município de São Gabriel do Oeste, MS............................... 20

Tabela 2 Análise química e granulométrica do substrato utilizado no experimento de casa-de-vegetação...............................................

Tabela 3 Descrição dos tratamentos utilizados em Bidens pilosa/Bidens subalternans e Amaranthus quitensis, no experimento instalado em condições de casa-de-vegetação............................................. 23

Tabela 4 Análise granulométrica e química de macro e alguns no micronutrientes presentes na mistura utilizada no experimento em casa-de-vegetação.............................................................. 26

Tabela 5 Tratamentos utilizados em Bidens pilosa/Bidens subalternans e Amaranthus quitensis

Tabela 6 Análise granulométrica e química de macro e alguns micronutrientes presentes na mistura utilizada no experimento.. $\quad 30$

Tabela 7 Tratamentos utilizados em Bidens pilosa/Bidens subalternans e Amaranthus quitensis

Tabela 8 Controle da planta daninha Bidens pilosa/Bidens subalternans, em experimento de campo aos 14 e 21 dias após a aplicação dos herbicidas (DAT)

Tabela 9 Porcentagem de controle dos biotipos resistentes e suscetíveis de Bidens pilosa/Bidens subalternans aos 7 e 14 DAT, em casa-de-vegetação.

Tabela 10 Produção de biomassa verde aos 16 DAT e biomassa seca dos biotipos resistentes e suscetíveis de Bidens pilosa/Bidens subalternans. 


\section{Página}

Tabela 11 Porcentagem de controle dos biotipos de Amaranthus quitensis resistentes e suscetíveis aos 7 e 14 DAT,em casa-de-vegetação.. 44

Tabela 12 Produção de biomassa verde aos 16 DAT e biomassa seca dos biotipos resistentes e suscetíveis de Amaranthus quitensis..........

Tabela 13 Parâmetros estimados para equação de Richards Function, na análise de crescimento dos biotipos resistentes e suscetíveis de Bidens pilosa/Bidens subalternans.

Tabela 14 Parâmetros estimados para equação de Richards Function, na análise de crescimento dos biotipos resistentes e suscetíveis de Amaranthus quitensis

Tabela 15 Acumulação de acetolactato pelos biotipos resistentes e suscetíveis de Bidens pilosa/Bidens subalternans.

Tabela 16 Acumulação de acetolactato pelos biotipos resistentes e suscetíveis de Amaranthus quitensis

Tabela 17 Estimativas dos parâmetros e respectivos desvios padrões assintóticos dos biotipos resistentes e suscetíveis de Bidens pilosa/Bidens subalternans, segundo as variáveis avaliadas.......

Tabela 18 Estimativas dos parâmetros e respectivos desvios padrões dos biotipos resistentes e suscetíveis de Amaranthus quitensis, segundo as variáveis avaliadas.

Tabela 19 Estimativa do $\mathrm{GR}_{50}$ e taxa de resistência (R/S) dos biotipos resistentes e suscetiveis de Bidens pilosa/Bidens subalternans...

Tabela 20 Estimativa do $\mathrm{GR}_{50}$ e taxa de resistência (R/S) dos biotipos resistentes e suscetíveis de $A$. quitensis. 


\title{
BIOLOGIA, MANEJO E CARACTERIZAÇÃO BIOQUÍMICA E GENÉTICA DE BIOTIPOS DE PLANTAS DANINHAS RESISTENTES AOS HERBICIDAS INIBIDORES DA ACETOLACTATO SINTASE
}

\author{
Autora: PATRÍCIA ANDREA MONQUEIRO \\ Orientador: PEDRO JACOB CHRISTOFFOLETI
}

\section{RESUMO}

As plantas daninhas Bidens pilosa/Bidens subalternans e Amaranthus quitensis são controladas na cultura da soja por diversos herbicidas; sendo que os herbicidas inibidores da acetolactato sintase (ALS - código EC 4.1.3.18) são os mais utilizados pelos sojicultores. O uso intensivo e repetitivo destes herbicidas em áreas cultivadas com soja no município de São Gabriel do Oeste (MS, Brasil) e nas províncias de Córdoba e Tucumã (Argentina), selecionou biotipos resistentes destas plantas daninhas. Sendo assim, a presente pesquisa foi desenvolvida, com o objetivo de estudar a biologia, manejo e a caracterização bioquímica e genética, destes biotipos de plantas daninhas. Através dos ensaios conduzidos em condições de casa-de-vegetação, onde foram obtidas as curvas de dose-resposta e $\mathrm{GR}_{50}$, foi comprovada a resistência cruzada às imidazolinonas e sulfoniluréias, dos biotipos de Bidens pilosa/Bidens subalternans e Amaranthus quitensis. Em condições de campo, foi avaliado o controle do biotipo resistente de 
Bidens pilosa/Bidens subalternans, pelos herbicidas inibidores da ALS e alternativos (ou seja herbicidas com mecanismo de ação diferente dos inibidores da ALS). Concluiu-se que os herbicidas chlorimuron-ethyl e imazethapyr, nas doses recomendadas foram ineficientes no controle da planta daninha, porém os herbicidas alternativos, como o lactofen, fomesafen e bentazon foram eficazes. Sementes de Bidens pilosa/Bidens subalternans provenientes de plantas que não foram controladas no experimento de campo pelos herbicidas inibidores da ALS, e de Amaranthus quitensis de plantas escapes na Argentina, foram coletadas e utilizadas para a instalação de um ensaio em casa-de-vegetação, em vasos, onde foram testados os mesmos tratamentos aplicados no experimento de campo. Os resultados comprovaram que os herbicidas alternativos aplicados isoladamente ou em mistura com os herbicidas inibidores da ALS, controlaram eficientemente tanto as populações resistentes, como as suscetíveis, sendo portanto uma alternativa no manejo de populações resistentes. Foram realizadas análises de crescimento comparativa entre os biotipos resistente (R) e suscetível (S) destas espécies daninhas, com o objetivo de estimar a habilidade competitiva. As plantas resistentes não sofreram custo adaptativo, não havendo portanto, diferenças na adaptabilidade ecológica entre os biotipos. Foi conduzido um bioensaio para teste rápido de resistência destes biotipos aos herbicidas inibidores da ALS através da aplicação simultânea dos herbicidas inibidores da ALS e KARI (enzima que atua na reação imediatamente após a formação de acetolactato). Os resultados de acumulo de acetolactato em plantas resistentes foram medidos através da formação de acetoína cuja concentração foi medida em espectofotômetro observando-se a coloração desenvolvida quando em solução com naftol e creatina, através deste teste foi confirmada a resistência dos biotipos $\mathrm{R}$ testados, tanto de Bidens pilosa/Bidens subalternans quanto de Amaranthus quitensis, pois quanto maior a quantidade de acetoína, maior é a atividade da enzima e mais intensa é a cor desenvolvida, proporcionando valores maiores nas leituras de 
absorbância. O sequenciamento do gen que codifica a enzima ALS em plantas resistentes e suscetíveis de Amaranthus quitensis, demonstrou não haver mutação na região de Domínio A, sugerindo que outras posições do gene devem possuir mutações que conferem resistência. 


\title{
BIOLOGY, MANAGEMENT AND BIOCHEMICAL/GENETIC CARACTERIZATION OF RESISTANT WEED BIOTYPES TO ACETOLACTATE SYNTHASE INHIBITOR HERBICIDES
}

\author{
Author: PATRICIA ANDREA MONQUEIRO \\ Adviser: PEDRO JACOB CHRISTOFFOLETI
}

\section{SUMMARY}

The weeds Bidens pilosa/Bidens subalternans and Amaranthus quitensis are controlled in the soybean crop by herbicides; but the acetolactate synthase (ALS - code EC 4.1.3.18) inhibitor herbicides are the most sprayed by soybean growers. However, the intensive and repetitive use of these herbicides in São Gabriel do Oeste county (MS - Brazil) and in the provinces of Córdoba and Tucumã (Argentina), selected resistant biotypes of these weeds. Therefore, it was developed a research project aiming to study the biology, management and the genetic/biochemical caracterization, using these weed biotypes. From greenhouse experiments dose-response curves and $\mathrm{GR}_{50}$ values were obtained, proving the cross resistance to imidazolinones and sulfonylureas of Bidens pilosaiBidens subalternans and Amaranthus quitensis. It was also evaluated, under field conditons, the control of the resistant biotype of Bidens pilosa/Bidens subalternans to ALS inhibitor herbicides and alternatives (herbicides with 
different mechanism of action from ALS inhibition). It was concluded that the herbicide chlorimuron-ethyl and imazethapyr, at reccommended rate did not control the resistant biotype, but the alternative herbicides lactofen, fomesafen and bentazon were efficient. Seeds of Bidens pilosa Bidens subalternans from plants of the ALS inhibitor herbicides failure in the field experiment and Amaranthus quitensis scapes from Argentina, were collected and used to install experiments in the greennhouse, whete it was tested the same treatements used in the field experiment. The results proved that alternative herbicides, sprayed alone, or in mixture with ALS inhibitor, controlled efficently both resistant and susceptible populations. It was conducted experiments of growth analysis of the resistant and susceptible biotypes of these weeds, in order to compare the competitive ability of the biotypes. According to the results, there is no adaptative cost to the resistant biotype. It was conducted a bioassay, in order to test a rapid detection of resistant biotypes to ALS inhibitor herbicides, spraying at the same time inhibitor herbicides of ALS and KARI (an enzy me that act in the reaction right after the acetolactate formation). The results of the acetolactate accumulation in resistant plants was meassured by the accumulation of acetoin, which concentration was meassured by the color of the solution developed in naphtol and creatine. By this test it was possible to confirm the resistance of the biotypes of Bidens pilosa/Bidens subalternans and Amaranthus quitensis due to an insensitivity of the ALS. The sequencing of the gen that codify the ALS in resistant and susceptible of Amaranthus quitensis, did not show any mutation in the Domain A, suggesting that other possitions of the gen could be mutated that confer insensitivity of the ALS. 


\section{INTRODUÇÃO}

A resistência de plantas daninhas aos herbicidas é uma resposta evolutiva destas espécies de plantas às práticas agrícolas. O controle químico de plantas daninhas tomou grande impulso na agricultura, no período pós-guerra, através da descoberta da ação herbicídica do 2,4-D no controle de plantas daninhas folhas largas em culturas de cereais. Desde então, as indústrias químicas têm desenvolvido novas moléculas, as quais, têm sido adotados largamente na agricultura.

Devido ao uso intensivo destes produtos, em muitas regiões, como o único método de controle de plantas daninhas, ocorreu uma pressão de seleção ocasionando o aparecimento de biotipos de plantas daninhas resistentes aos herbicidas. Áreas agrícolas com ocorrência de biotipos resistentes tem aumentado devido à introdução de novos grupos químicos de herbicidas, dentre eles as sulfoniluréias, imidazolinonas, triazolopyrimidinas e pyrimidil thiobenzoatos, que inibem a acetolactato sintase (ALS). também chamada de acetohydroxyacido synthase (AHAS), que catalisa a primeira reação na produção dos aminoácidos alifáticos de cadeia ramificada valina, leucina e isoleucina.

No Brasil, a preocupação com o fenômeno de resistência tem se intensificado devido ao aparecimento de biotipos de Bidens pilosa/Bidens subalternans resistentes aos herbicidas inibidores da ALS, em áreas cultivadas com soja. Do mesmo modo, biotipos resistentes de Amaranthus quitensis vêm surgindo em áreas cultivadas com soja nas províncias de Córdoba e Tucumã na Argentina. 
Com o objetivo de estudar a biologia, manejo e caracterização bioquímica e genética de biotipos de Bidens pilosa/Bidens subalternans e Amaranthus quitensis resistentes aos inibidores da ALS, foram realizadas ensaios com os seguintes objetivos:

- Avaliação da sensibilidade de biotipos resistentes de Bidens pilosa/Bidens subalternans aos herbicidas inibidores da ALS e a herbicidas com outros mecanismos de ação (herbicidas alternativos) em condições de campo.

- Determinação da resistência cruzada e curvas de dose-resposta de populações resistentes $(\mathrm{R})$ e suscetíveis $(\mathrm{S})$ de Bidens pilosa/Bidens subalternans e Amaranthus quitensis aos herbicidas inibidores da ALS.

- Teste com diferentes herbicidas para manejo de populações $\mathrm{R}$ de Bidens pilosa/Bidens subalternans e Amaranthus quitensis aos herbicidas inibidores da ALS em condições de casa-de-vegetação.

- Análise de crescimento comparativa entre biotipos R e S de Bidens pilosa/Bidens subalternans e Amaranthus quitensis.

- Teste rápido da sensibilidade da ALS dos biotipos R e S de Bidens pilosa/Bidens subalternans e Amaranthus quitensis através de bioensaio.

- Sequenciamento da região de domínio A do gene que confere resistência aos herbicidas inibidores da ALS em Amaranthus quitensis. 


\section{REVISÃO DA LITERATURA}

\subsection{Resistência de Plantas Daninhas aos Herbicidas}

Muitas definições têm sido propostas para o termo resistência das plantas daninhas aos herbicidas. Gressel \& Segel (1978) definiram como resistentes as plantas que sobrevivem a doses que normalmente controlam plantas suscetíveis da mesma espécie. Para Warwick (1991) a resistência é resultado da seleção ou da resposta genética à repetidas exposições a herbicidas com mecanismos de ação similares. Sawicki (1987) propõe uma definição que incorpora não somente a dose recomendada mas também o conceito de evolução, realçando que a resistência marca uma resposta genética à seleção imposta pelos herbicidas.

Holt \& LeBaron (1990) afirmam que qualquer definição do termo resistência deve estar relacionada com a utilização do herbicida no campo, em sua dose recomendada para o controle das plantas daninhas. É importante destacar a diferença entre resistência e tolerância. A resistência pode denotar a habilidade da população de plantas, dentro de uma espécie, de resistir a doses maiores do que os biotipos predominantes na população selvagem podem suportar. A tolerância, é a habilidade natural de algumas espécies em tolerar o produto tóxico, mesmo que estas populações nunca tenham sido expostas ao herbicida.

Outra definição diz respeito aos termos resistência cruzada e resistência múltipla. No primeiro caso, Heap (1997) descreve a resistência cruzada quando biotipos de plantas daninhas são resistentes a dois ou mais herbicidas devido à presença de um único mecanismo de resistência. Ponchio (1996), identificou 
biotipos de Bidens pilosa que desenvolveram resistência cruzada aos herbicidas dos grupos químicos das sulfoniluréias e das imidazolinonas devido a insensibilidade da ALS à ação dos herbicidas. Além de concordar com este aspecto, Rubim (1991) complementa que o termo resistência múltipla deve ser usado em casos quando a planta resistente possui dois ou mais mecanismos de resistência distintos, como foi identificado em biotipos de Kochia scoparia que possuem resistência aos herbicidas inibidores da ALS e às triazinas devido a uma mutação no gene que codifica a ALS e no gene que codifica a proteína Dl, respectivamente.

Atualmente, segundo Herbicide Resistance Action Commitee (HRAC) há cerca de 218 biotipos de plantas daninhas, distribuído em 145 espécies. De acordo com o autor, a porcentagem de plantas resistentes no período de 1984-1997 era de $28 \%$ resistentes aos herbicidas inibidores da ALS, $15 \%$ às triazinas, $15 \%$ aos bipiridilos, $12 \%$ as uréias e amidas, $11 \%$ aos inibidores da ACCase, $4 \%$ às dinitroanilinas e o restante distribuídos em diversas outras classes químicas. (Heap, 1999).

O desenvolvimento da resistência das plantas daninhas aos herbicidas é influenciado por vários fatores. Entre eles, existem os fatores ligados ao produto químico, como por exemplo, herbicidas altamente eficientes, herbicidas que apresentam um único sítio de ação, herbicidas com residual prolongado e a utilização intensiva do mesmo herbicida ou de herbicidas com o mesmo mecanismo de ação selecionam mais rapidamente o biotipo resistente. A biologia da planta daninha também pode afetar a taxa na qual a resistência se desenvolve, por exemplo, as plantas daninhas de ciclo anual podem desenvolver resistência mais rapidamente do que as espécies bianuais ou perenes, pois um maior número de gerações serão submetidas ao agente selecionador. A diversidade genética é de fundamental importância no desenvolvimento da resistência, algumas espécies possuem uma alta taxa natural de mutações gênicas conferindo resistência a uma 
classe de herbicidas antes mesmo que ele seja aplicada no campo. Muitas vezes a característica de resistência pode também ser disseminada através do pólen e sementes, aumentando, assim o fluxo gênico que confere resistência para áreas adjacentes.

\subsection{Resistência das Plantas Daninhas aos Herbicidas Inibidores da ALS}

A acetolactato sintase é o sítio de ação dos grupos de herbicidas sulfoniluréias, imidazolinonas, triazolopyrimidinas e pyrimidil thiobenzoatos. A ALS é a primeira enzima na biossíntese dos aminoácidos valina, leucina e isoleucina, catalisando duas reações paralelas: condensação de 2 mols de piruvato para formar acetolactato e condensação de $1 \mathrm{~mol}$ de piruvato com $1 \mathrm{~mol}$ de 2 oxibutirato para formar acetohidroxibutirato (Eberlein et al., 1997). Estes herbicidas têm ganhado popularidade na comunidade agrícola devido à alta eficácia no controle de várias espécies de plantas daninhas, baixas doses recomendadas; baixa toxicidade aos mamíferos e seletividade a várias culturas.

A seletividade destes herbicidas em algumas culturas, como soja [Glycine $\max (\mathrm{L})$ Merrill] e trigo (Triticum aestivum L.) é baseada primeiramente na habilidade das plantas em metabolizar o herbicida rapidamente em formas não tóxicas (Sweester et al., 1982). Do mesmo modo, várias espécies de plantas daninhas, como Echinochloa crus-galli (L) Beauv; Solanum nigrum (L) e Sorghum halepense (L) Pers; são naturalmente tolerantes a certos inibidores da ALS pela inativação metabólica (Hutchison et al., 1984).

As plantas daninhas resistentes aos herbicidas inibidores da ALS têm-se tornado um problema crescente em vários países. O primeiro caso registrado de resistência. foi relatado por Mallory-Smith et al. (1990) e Primiani et al. (1990), que identificaram biotipos resistentes de Lactuca serriola e Kochia scoparia em 
áreas cultivadas com trigo, nos Estados Unidos da América do Norte, em apenas cinco anos após a liberação comercial do herbicida chlorsulfuron. Atualmente há problemas de resistência em cerca de 53 espécies de plantas daninhas em várias regiões do mundo, como por exemplo, Amaranthus rudis (Lovell et al., 1996; Foes et al., 1998); Galium spurium (Hall et al., 1998); Sisymbruim orientale (Boutsalis et al., 1998); Bidens pilosa (Ponchio, (1996); Christoffoleti et al. (1996)), Euphorbia heterophylla (Gazieiro et al., 1998 ) e Stellaria media (Kudsk et al., 1995).

Os biotipos resistentes às triazinas, por exemplo, apresentam um efeito pleiotrópico na taxa fotossintética; no entanto segundo Christoffoleti (1993) biotipos resistentes aos herbicidas inibidores da ALS, não sofrem custo adaptativo, portanto, as plantas resistentes podem permanecer na mesma proporção na população de campo, mesmo após a remoção do agente selecionador. Adicionalmente, a freqüência de mutação do alelo que confere resistência a estes herbicidas é naturalmente maior do que das triazinas, ao redor de $10^{-6}$, segundo Stannard \& Fay (1987). Considerando essa freqüência, Thill et al. (1991) estimaram que a resistência pode se estabelecer no campo após 3-5 anos de aplicação intensiva do herbicida chlorsulfuron.

A herdabilidade do alelo que confere resistência aos herbicidas inibidores da ALS é uma característica semi dominante, permitindo a sobrevivência de indivíduos homozigotos e heterozigotos (Mallory Smith et al., 1990), podendo também, ser disseminada através do pólen e sementes, aumentando assim, o fluxo gênico que confere resistência para áreas adjacentes.

A determinação da freqüência inicial de um biotipo resistente em condições de campo é muito difícil, pois é influenciada pela pressão de seleção, características genéticas de resistência e dinâmica populacional das plantas daninhas. Desta forma, são poucos os trabalhos encontrados na literatura que fazem previsões do aparecimento de resistência em função do número de 
aplicações do herbicida selecionador da resistência. Lovell et al. (1996) relataram o aparecimento de biotipos resistentes de Amaranthus rudis após 2 aplicações sucessivas dos herbicidas inibidores da ALS, mostrando que a dose de imazethapyr requerida para inibir a atividade da ALS em 50\% foi 520 vezes maior para o biotipo resistente do que para o biotipo suscetível. Jeffers et al. (1996) afirmaram que uma população de Brassica kaber desenvolveu resistência após um ano de uso do herbicida ethametsulfuron, sugerindo uma freqüência inicial bastante alta de plantas daninhas resistentes na população de campo.

Nos modelos teóricos de previsão do aparecimento de resistência é necessário incluir como componente o comportamento biológico de biotipos resistentes e suscetíveis. A adaptabilidade ecológica dos biotipos deve levar em conta a germinação, estabelecimento, sobrevivência, crescimento e fecundidade das plantas.

Neste aspecto, Gurjett et al. (1996) observaram que biotipos resistentes de Lactuca serriola às sulfoniluréias germinaram tão rápido quanto os biotipos suscetíveis desta espécie. Do mesmo modo, estes autores não observaram diferenças entre biotipos resistentes e suscetíveis de Lolium rigidum, com relação à dormência das sementes e a taxa de crescimento.

Dyer et al. (1993) mostraram que as sementes de Kochia scoparia resistentes aos herbicidas inibidores da ALS, germinaram mais rápido do que as sementes da população sensível, na temperatura de $4,6^{\circ} \mathrm{C}$, mas não em $10,6^{\circ} \mathrm{C}$. Encontraram também um elevado nível de valina, leucina e isoleucina livre nas sementes resistentes, propondo que isto poderia ser a possível causa para a germinação mais rápida. Do mesmo modo, Eberlein et al. (1997) analisaram a concentração de aminoácidos nas sementes de biotipos resistentes e suscetíveis de Lactuca serriola e indicaram que a concentração de leucina e valina foram 18 e $41 \%$ maiores respectivamente, em sementes resistentes, enquanto a concentração de isoleucina foi similar entre os dois biotipos. Este fato é associado com a 
germinação mais rápida de biotipos resistentes, o que pode ser uma vantagem ecológica em alguns nichos, pois permite o rápido estabelecimento das plantas na captura de espaço.

Christoffoleti (1993), constatou através de pesquisas em casa-de-vegetação e campo, que não há diferenças na adaptabilidade ecológica de biotipos resistentes e suscetíveis de Kochia scoparia aos herbicidas inibidores da ALS, portanto, a mutação responsável pela resistência destes biotipos de plantas daninhas não resultou em um custo genético para o biotipo resistente.

Eberlein et al. (1997) relataram que o Km (piruvato) da ALS isolada dos biotipos resistentes de Lactuca serriola foi similar ao Km da ALS de plantas suscetíveis, sugerindo que a mutação para a resistência não altera a síntese de acetolactato. Estes mesmos autores verificaram que a atividade específica da ALS em plantas resistentes foi $57 \%$ menor do que a atividade desta enzima em plantas suscetíveis, sugerindo que a mutação que confere resistência pode afetar a função, expressão ou a estabilidade da enzima. Em contraste, a atividade da ALS de biotipos resistentes e suscetíveis de Kochia scoparia, Stellaria media (L); Salsola iberica e Lolium perenne (L), ao chlorsulfuron foram similares. É necessário, ainda, um maior número de pesquisas, principalmente em condições de campo, para compreensão das diferenças na adaptação ecológica entre indivíduos suscetíveis e resistentes aos herbicidas.

Existem diversas metodologias de pesquisa que estão sendo estudas com o objetivo de identificação da resistência de plantas daninhas aos herbicidas. Gerwick et al. (1993); Simpson et al. (1995) e Lovell et al. (1996b), desenvolveram um diagnóstico rápido para se detectar a resistência, através de um ensaio com a ALS no qual o ácido ciclopropanodicarboxílico (CPCA) é usado para inibir a cetoácido reductoisomerase (KARI), enzima que cataliza a reação seguinte ao acetolactato na cadeia de biossíntese dos aminoácidos valina. leucina e isoleucina, provocando acumulo deste produto. Quando um herbicida inibidor 
da ALS é aplicado juntamente com CPCA em uma planta suscetível, o acetolactato não se acumula. O contrário acontece em plantas resistentes, pois nestas plantas, a enzima ALS é insensível à ação do herbicida. Quando a quantificação do acetolactato acumulado é desejada. utiliza-se o método de Westerfeld (1945) que tem como princípio a formação de um complexo colorido devido a reação entre acetoína, creatina e naphtol, cuja densidade ótica a 530nm é proporcional à concentração do acetolactato formado na reação.

$\mathrm{Na}$ maior parte dos casos de resistência de plantas daninhas aos herbicidas inibidores da ALS, o mecanismo de resistência é decorrente de uma alteração da ALS no sítio de ação do herbicida, que a torna insensível à ação deste herbicida .

A ALS possui 670 aminoácidos e dois tipos de alterações nas proteínas dominantes, codificadas pelo gene da ALS, parecem influenciar a resistência. O primeiro chamado de domínio A, uma região com 13 aminoácidos, altamente conservada, que pode conferir resistência em plantas daninhas e cultivadas e o segundo de domínio B, que amplifica o nível de resistência de Tabaco (Guttieri et al., 1992).

Guttieri et al. (1992) determinaram a seqüência de uma região de 196 pares de base do gene que codifica a enzima ALS de biotipos resistentes e suscetíveis de Kochia scoparia, Lactuca serriola e Salsola iberica. Na Lactuca serriola os genes dos biotipos resistentes e suscetíveis diferiram em um único ponto de mutação onde uma prolina foi substituída por uma histidina na posição 173. Para Kochia scoparia a diferença na seqüência de DNA entre os biotipos foi no mesmo ponto com a prolina sendo substituída pela threonina. Duas seqüências diferentes foram detectadas em biotipo resistente de Salsola iberica e, neste caso, nenhuma seqüência de codificação para substituição de aminoácidos foi diferente do biotipo suscetível.

Em estudos posteriores Guttieri et al. (1995) sequenciaram o gene que codifica a ALS de plantas resistentes e suscetíveis de Kochia scoparia e 
verificaram que as substituições foram variáveis, havendo mutações para threonina, serina, arginina, leucina, glutamina e alanina. Verificaram também, que algumas plantas que não apresentaram mutações no domínio A se mostraram resistentes devido a modificação da ALS, o que indica que outras regiões do gene da ALS podem sofrer alterações que causem resistência.

Bernasconi et al. (1995), clonaram e sequenciaram o gene mutante da ALS de dois isolados de Xanthuim $\mathrm{sp}$, que selecionaram resistência às imidazolinonas. Em um dos biotipos isolados o sequenciamento revelou que alanina na posição 57 foi substituída por threonina, a mesma mutação que ocorre no mutante comercial de milho gerado em laboratório (ICI 8532 IT). No outro biotipo resistente, altamente insensível a todos os grupos químicos inibidores da ALS, a modificação foi similar à outro mutante comercial de milho resistente da variedade, Pionner 31 80R, havendo uma modificação comum com a susbstituição de triptofano na posição 552 por leucina.

Foes et al. (1998) sequenciaram os genes que codificam a proteína Dl e a ALS de biotipos resistentes e suscetíveis de Amaranthus rudis, para se determinar a base genética da resistência múltipla aos herbicidas pertencentes aos grupos químicos das triazinas e inibidores da ALS. A resistência à triazinas foi conferida pela substituição da glicina por serina na posição 264 da proteína D1, enquanto que a resistência aos inibidores da ALS foi conferida pela substituição da leucina por triptofano na posição 569 do gene que codifica a ALS.

Em trabalhos posteriores Foes et al. (1999) determinaram a base molecular da resistência múltipla do biotipo de Kochia scoparia aos herbicidas inibidores da ALS e às triazinas, verificando que a resistência foi conferida pela substituição de uma leucina por triptofano na posição 570 do gene da ALS e de uma glicina por prolina na posição 264 do gene que codifica a proteína $\mathrm{D} 1$, respectivamente.

Jeffers et al. (1996) relataram que uma população resistente de Brassica kaper ao herbicida ethametsulfuron não apresentou resistência cruzada aos 
herbicidas chlorsulfuron, thifensulfuron, HOE 075032, imazamethabenz, imazethapyr, metribuzin e 2-4D, sugerindo que o mecanismo de resistência pode diferir de outros encontrados em plantas daninhas resistentes a sulfoniluréias, não envolvendo uma forma alterada da enzima ALS. Uma possibilidade, é que o ethametsulfuron foi metabolizado mais rapidamente nas populações resistentes.

Do mesmo modo, Lolium rigidum Gand e Alopecurus myosuroides foram descritos como resistentes às sulfoniluréias, através do aumento do metabolismo capaz de converter os herbicidas em compostos menos tóxicos (Kemp et al., 1990).

\subsection{As Plantas Daninhas Amaranthus quitensis, Bidens pilosa e Bidens subalternans}

\subsubsection{Amaranth us quitensis}

O gênero Amaranthus compreende mais de 50 espécies herbáceas, em sua maioria com ciclo de vida anual que crescem principalmente nas zonas tropicais e subtropicais. Dentre estas espécies, Amaranthus quitensis, é uma planta daninha de grande importância devido a sua agressividade em lavouras e áreas não cultivadas em países como Argentina, Uruguai, Paraguai e Bolívia. Faccini et al. (1994), afirmam que esta espécie é invasora de culturas de verão como soja, milho e girassol. Para Kissmann, (1992) e alguns autores brasileiros A. quitensis é sinônimo de $A$. hybridus ou uma variedade desta espécie.

Amaranthus quitensis é uma planta anual, ereta com até 2,0 metros de altura, com caule ereto e bastante ramificado, apresentando pigmentação vermelho-violácea por toda a planta. Folhas com formato ovalado-romboidal ou ovalado-lanceolado ou deltóide, largamente pecioladas, com ápice agudo ou subobtuso, mucronado e base atenuada com ângulo quase reto e pubescente na face dorsal. A inflorescência se apresenta tipo como glómerulos axilares e 
dicábios com brácteas maiores que os tépalos uninervais e aristadas, agrupados em espigas (Kissman,1992).

\subsubsection{Bidens pilosa e Bidens subalternans}

O gênero Bidens possui mais de quinze espécies de importância ao redor do mundo. No Brasil as espécies mais comuns são Bidens pilosa L e Bidens subalternans D.C., que parecem ser originário da América Tropical, mas atualmente tem distribuição cosmopolita ocorrendo em ambos os hemisférios.

Em muitas áreas no Mato Grosso do Sul e Mato Grosso a infestação de Bidens subalternans é muito alta, superando a de Bidens pilosa (Sanchez et al., 1997).

Estas espécies possuem quase todas as características morfológicas e biológicas de uma planta invasora típica: alta produção de sementes, podendo chegar a 3000 por planta, sementes com elevada viabilidade, rápido desenvolvimento vegetativo em condições de boa umidade e temperatura elevada, eficiente mecanismo de dispersão dos frutos, ocorrência de várias gerações durante o ano, porte herbáceo e tolerância a variados ambientes ecológicos (Tamashiro et al., 1978). Comportam-se como uma planta daninha anual de verão, alcançando entre 40 a $90 \mathrm{~cm}$ de altura.

As plantas pertencentes a espécie Bidens pilosa possuem ramificação dicotômica em toda a planta, aquênios com 3 aristas ou com 2 normais e uma menor ou com apenas 2 aristas. O segundo par de folhas apresenta folhas com grande lobo frontal ovalado e de margens regularmente denteadas. As folhas em plantas maiores são bastante irregulares e não apresentam características seguras de diferenciação com Bidens subalternans.

Bidens subalternans possui aquênios com 4 aristas, sendo comum se encontrar numa infrutescência aquênios com 4 aristas normais, com 3 ou 2 aristas. O segundo par de folhas se apresenta com um grande lobo frontal 
lobulado em vez de denteado.

Os capítulos em ambas as espécies apresentam um grande número de flósculos centrais tubulares e não ligulados, amarelos e alguns flósculos marginais com lígulas muito curtas, de coloração amarela clara ou esbranquiçada, às vezes totalmente ausentes (Kissmann, 1992).

As espécies de Bidens são controladas eficientemente pelos herbicidas imazethapyr, imazaquin, chlorimuron-ethyl, metsulfuron-methyl, nicosulfuron, flumetsulan, bentazon, lactofen, fomesafen entre outros (Rodrigues e Almeida, 1995).

\subsection{Manejo da Resistência}

É necessário modificar algumas práticas agrícolas de modo a prevenir ou retardar o estabelecimento da resistência em alguns biotipos de plantas daninhas (Gressel \& Segel, 1989).

A prática de rotação de culturas reduz o sucesso intrínseco das plantas daninhas, que estão em sincronia com a cultura e permite o uso de herbicidas alternativos, com diferentes mecanismos de ação, o que pode representar uma estratégia eficaz (Christoffoleti et al., 1994). Técnicas que reduzem o banco de sementes de plantas daninhas podem ser incorporadas dentro da prática de rotação de culturas, como: pastagem ou produção forrageira, períodos de pousio utilizando herbicidas não seletivos ou cultivadores, utilização de adubos verdes e queima de resíduos de plantas daninhas após a colheita (Powles \& Holtum, 1994).

O manejo racional de herbicidas é uma prática bastante importante, sendo que o uso de herbicidas sem nenhuma. ou com pouca atividade residual no solo e a otimização de doses e número de aplicações, reduzem a pressão de seleção. diminuindo os riscos de seleção de resistência de plantas aos herbicidas. Da mesma forma a rotação de herbicidas com diferentes mecanismos de ação diminui 
consideravelmente a pressão de seleção para biotipos resistentes (Christoffoleti et al., 1994).

O uso de misturas de herbicidas para manejo e prevenção da resistência está baseado no fato que os ingredientes ativos controlam eficientemente os dois biotipos da mesma espécie, ou seja o biotipo resistente a um dos herbicidas é controlado pelo outro ingrediente ativo da mistura (Powles \& Holtum, 1994). É importante ressaltar que a mistura de herbicidas de diferentes mecanismos de ação como forma de manejo e prevenção de resistência, é mais eficiente quando o sistema de reprodução da planta daninha é a autogamia, pois a recombinação gênica de diferentes alelos que conferem resistência tem menor probabilidade de ocorrer em relação a plantas alógamas (Gould, 1995).

Outras alternativas para prevenção e manejo da resistência podem ser: cultivo de culturas mais competitivas, espaçamento mais adensado, controle biológico e uso de cobertura morta. É interessante manter um histórico de cada área da propriedade para se identificar a evolução da população de determinadas espécies, pois normalmente, a ocorrência dos biotipos resistentes não pode ser detectada durante os primeiros anos de aplicação do agente de seleção, ou seja, quando percebermos a falta de controle de uma espécie que tradicionalmente era controlada por certo herbicida, já se decorreram diversos anos do início da seleção do biotipo resistente. Sendo assim, as principais formas de manejo e prevenção da resistência estão todas relacionadas ao manejo integrado de plantas daninhas.

\subsection{Modelos Estatísticos de Análise de Resultados Experimentais}

\subsubsection{Estabelecimento de Curvas de Dose-Resposta}

A análise dos resultados da resposta das plantas aos herbicidas através de curvas de dose-resposta é uma importante ferramenta na ciência de plantas 
daninhas, pois permite a interpretação dos resultados de forma objetiva e possibilita comparação adequada entre tratamentos.

Seefeldt et al. (1995) propõem um modelo log-logístico como método eficaz na análise de curvas de dose-resposta. Dentre os parâmetros da equação pode ser destacado o valor do $\mathrm{GR}_{50}$, que é a dose necessária para que a resposta da planta seja metade da resposta total. Os autores apresentam em seu trabalho sugestão de procedimentos para utilização do programa SAS (Statistical Analysis System) na análise dos resultados. Curvas típicas de dose-resposta tem o formato sigmóide, sendo que a expressão matemática que relaciona a resposta $(\mathrm{y})$ e dose (x) é:

$$
y=\frac{D-C}{1+\exp ^{\left[b\left(\log (x)-\log \left(G R_{50}\right)\right]\right.}+C}
$$

onde C corresponde à resposta em altas doses; D corresponde à resposta do controle; b é a declividade da curva e $\mathbf{G R}_{\mathbf{5 0}}$ é a dose que corresponde a $50 \%$ da resposta.

Algumas vezes doses muito baixas dos herbicidas provocam efeitos estimulantes, neste caso, é adicionada à expressão do modelo log-logístico uma função que descreva o formato da curva contendo os pontos de efeito estimulante (Brain \& Cousens, 1989).

Seefeldt et al. (1994), utilizou o modelo log-logístico para determinar as curvas de dose-resposta de biotipos resistentes e suscetiveis de Avena fatua aos herbicidas diclofop-methyl, e outros herbicidas inibidores da ACCase. O modelo utilizado possibilitou estimar a taxa de resistência e que os biotipos diferiram significativamente em suas respostas aos herbicidas. As curvas encontradas foram não paralelas, indicando que possuem os parâmetros $\mathbf{C}$ e $\mathbf{D}$ iguais, $\mathbf{b}$ diferentes e $\mathbf{G R}_{\mathbf{5 0}}$ estimado para cada biotipo. Outras funções podem ser usadas em casos 
onde o comportamento da variável dependente não segue um formato sigmóide como as equações seguintes:

$$
Y=A^{*} X /(B+X)
$$

onde $\mathrm{Y}$ é a resposta da planta, que neste caso foi a porcentagem de controle das plantas daninhas; X representa a dose do herbicida; B é o coeficiente de declividade e A é a assíntota máxima.

$$
Y=\exp \left(A+B^{*} X\right)
$$

onde $\mathrm{Y}$ é a resposta da planta, que neste caso foi a produção de biomassa pelas plantas após o tratamento com herbicida; X representa a dose do herbicida; A é a assíntota; e B é o coeficiente de declividade.

\subsubsection{Análise de Crescimento}

Várias funções assintóticas têm sido utilizadas na análise de crescimento, porém, a função polinomial assintótica Richards Function (RF) é a mais comum nestes estudos.

$$
\log _{e}^{W}=\log _{e}^{A}-\frac{1}{N} * \log _{e}^{\left(1 \pm e^{\left(-k *\left(T-T_{0}\right)\right.}\right)}
$$

o parâmetro $\mathbf{N}$ determina a forma da curva e a posição do ponto de inflexão; $\mathbf{A}$ representa a assíntota máxima no tempo infinito; $\mathbf{K}$ é a taxa em que $\mathbf{A}$ é atingido: To estima o tempo a partir do qual a curva é superior a zero.

O modelo polinomial Richard Function foi utilizado por Christoffoleti (1993) para análise de crescimento de biotipos resistentes e suscetíveis de Kochia 
scoparia, aos herbicidas inibidores da ALS, analisando o peso da biomassa verde, peso da biomassa seca e área foliar até o início do florescimento. Foi concluído através destas análises que ambos biotipos apresentam a mesma performance em relação ao crescimento e desenvolvimento. 


\section{MATERIAL E MÉTODOS}

\subsection{Avaliação da sensibilidade de biotipos resistentes de Bidens pilosa/Bidens subalternans aos herbicidas inibidores da enzima ALS e a herbicidas com outros mecanismos de ação (herbicidas alternativos) em condições de campo}

\subsubsection{Local}

O experimento foi instalado na Fazenda Ponte Vermelha, município de São Gabriel do Oeste, MS, no dia 22 de dezembro de 1997, em área cultivada com a cultura de soja, onde o manejo de plantas daninhas do tipo folha larga vinha sendo feita há pelo menos oito anos através de herbicidas pertencentes aos grupos químicos das imidazolinonas (imazaquin e imazethapyr) e sulfuniluréias (chlorimuron -ethyl). Dentre as plantas daninhas infestante da área, o picão-preto (mistura de Bidens pilosa e Bidens subalternans) era uma das mais abundantes, no entanto, nos últimos anos, os índices de controle obtidos tem sido abaixo do normalmente esperado. Suspeitou-se portanto que na área, onde foi instalado o experimento, existia uma população de picão-preto com predominância de um biotipo resistente aos herbicidas inibidores da ALS.

\subsubsection{Tratamentos utilizados}

O delineamento experimental adotado foi de blocos ao acaso com dez tratamentos e quatro repetições. As parcelas possuíam área útil de $24 \mathrm{~m}^{2}$, ou seja 8 linhas de soja espaçadas de $0,5 \mathrm{~m}$, por 6,0 metros de comprimento, onde foram 
feitas as aplicações dos herbicidas testados.

Os tratamentos utilizados, doses de ingrediente ativo e produto comercial por hectare, estão apresentados no Tabela 1. A aplicação foi realizada no dia 22 de dezembro de 1997, com pulverizador costal pressurizado com $\mathrm{CO}_{2}$, munido de 8 bicos, com ponta XR 110 02, aplicando um volume de calda correspondente a $200 \mathrm{~L} / \mathrm{ha}$, com pressão de trabalho de $30 \mathrm{lb} / \mathrm{pol}^{2}$. As condições ambientais foram: temperatura de $29^{\circ} \mathrm{C}$, umidade relativa do ar no início da aplicação (8:15 horas) de $56 \%$ e no final da aplicação (10:00 horas) de 70\%. A população predominante no momento da aplicação era de picão-preto; constituído de uma mistura de Bidens pilosa e Bidens subalternans, com cerca de $85 \%$ de infestação, no estádio de 4-6 folhas definitivas.

\subsubsection{Avaliações}

Foram realizadas avaliações visuais sobre a porcentagem de controle das plantas aos 14 e 21 dias após a aplicação dos herbicidas (DAT). Para quantificar o controle do picão-preto através dos herbicidas utilizou-se uma escala visual atribuindo a nota 0 para nenhum controle e 100 para controle total, comparados à testemunha.

\subsubsection{Análise dos dados}

Os dados foram submetidos à análise de variância para obtenção do valor de F. Sendo este significativo, foram comparadas as médias através do teste Tukey. Para análise estatística os resultados das quatro repetições foram transformados para arcsen $\sqrt{\% / 100}$ 
Tabela 1 - Descrição dos tratamentos utilizados no experimento instalado no município de São Gabriel do Oeste, MS.

\begin{tabular}{|c|c|c|c|c|c|}
\hline \multirow[b]{2}{*}{ Trat. } & \multicolumn{2}{|l|}{ Herbicida } & \multirow{2}{*}{$\begin{array}{l}\text { i.a. } \\
\text { g/ha }\end{array}$} & \multirow{2}{*}{$\begin{array}{c}\text { p.c. } \\
\text { g ou L/ha }\end{array}$} & \multirow{2}{*}{$\begin{array}{c}\text { Adjuvante } \\
\text { (Agral) }\end{array}$} \\
\hline & i.a. & p.c. & & & \\
\hline 1 & chlorimuron-ethyl & Classic & 20,0 & 80 & $0,2 \%$ \\
\hline 2 & $\begin{array}{c}\text { chlorimuron-ethyl + } \\
\text { lactofen }\end{array}$ & $\begin{array}{c}\text { Classic }+ \\
\text { Cobra }\end{array}$ & $12,5+120$ & $50+0,5$ & - \\
\hline 3 & $\begin{array}{l}\text { chlorimuron-ethyl + } \\
\text { fomesafen }\end{array}$ & $\begin{array}{c}\text { Classic }+ \\
\text { Flex }\end{array}$ & $12,5+150$ & $50+0,6$ & $0,2 \%$ \\
\hline 4 & $\begin{array}{c}\text { chlorimuron ethyl }+ \\
\text { bentazon }\end{array}$ & $\begin{array}{l}\text { Classic }+ \\
\text { Basagran }\end{array}$ & $12,5+384$ & $50+0,8$ & $0,2 \%$ \\
\hline 5 & $\begin{array}{l}\text { chlorimuron ethyl + } \\
\text { imazethapyr }\end{array}$ & $\begin{array}{c}\text { Classic }+ \\
\text { Pivot }\end{array}$ & $12,5+50$ & $50+0,5$ & - \\
\hline 6 & lactofen & Cobra & 192 & 0,8 & - \\
\hline 7 & Fomesafen & Flex & 225 & 0,9 & $0,2 \%$ \\
\hline 8 & Bentazon & Basagran & 480 & 1,0 & $0,2 \%$ \\
\hline 9 & Imazethapyr & Pivot & 100 & 1,0 & $0,2 \%$ \\
\hline 10 & Testemunha & - & - & - & - \\
\hline
\end{tabular}

i.a. $=$ Ingrediente Ativo

p.c. $=$ Produto Comercial

Adjuvante Agral foi adicionado nos tratamentos em que é recomendado, na dose de $0,2 \% \mathrm{v} / \mathrm{v}$. 
3.2. Determinação da resistência cruzada e curvas de dose-resposta de populações resistentes (R) e suscetíveis (S) de Bidens pilosa/Bidens subalternans e Amaranthus quitensis aos herbicidas inibidores da ALS

\subsubsection{Local}

O experimento foi conduzido em casa-de-vegetação do Departamento de Produção Vegetal da Escola Superior de Agricultura "Luiz de Queiroz" Universidade de São Paulo, Piracicaba - SP.

\subsubsection{Material Vegetal}

A metodologia descrita a seguir foi inicialmente desenvolvida por Saari et al. (1992), e é usada neste experimento com algumas modificações.

Sementes de Bidens pilosa/Bidens subalternans e Amaranthus quitensis foram coletadas em áreas produtoras de soja dos municípios de São Gabriel do Oeste (Brasil) e Córdoba (Argentina), respectivamente. Em São Gabriel do Oeste as sementes foram coletadas de várias plantas que sobreviveram aos tratamentos com herbicidas inibidores da ALS, do experimento de campo, descrito anteriormente. Nesta área manejo de plantas daninhas do tipo folha larga apresentava histórico de pelo menos oito anos de uso consecutivo de herbicidas inibidores da ALS.

As sementes de Amaranthus quitensis foram coletadas na Argentina, à partir de plantas remanescentes da aplicação de herbicidas inibidores da ALS, em um experimento conduzido pelo pesquisador do INTA, Hugo Bergener. Segundo informações deste pesquisador, nesta área o manejo de plantas daninhas do tipo folha larga tinha sido feito por diversos anos consecutivos (pelo menos 8 anos) com herbicidas inibidores da ALS, e o controle nos últimos anos, da planta daninha caruru. tem sido falho. Entretanto em populações normais estes herbicidas tem apresentado excelente controle. 
Outras amostras de sementes de Bidens pilosa/Bidens subalternans e Amaranthus quitensis foram coletadas de áreas que nunca receberam pulverizações com os herbicidas inibidores da ALS, sendo portanto, essas populações denominadas de biotipos suscetíveis (S).

As sementes destas plantas daninhas foram semeadas separadamente, em copos plásticos de capacidade de $200 \mathrm{ml}$, contendo substrato a base de solo e material orgânico, na proporção 3:1 (análise química e granulométrica, vide Tabela 2). Os vasos foram irrigados de acordo com a necessidade, para manter umidade satisfatória. Vasos com plantas uniformes e vigorosas com 4 folhas definitivas foram selecionados para os tratamentos com herbicidas.

\subsubsection{Tratamentos}

Os herbicidas foram aplicados sobre a parte aérea das plantas com um pulverizador de laboratório acionado por um motor elétrico, ponta de pulverização do tipo leque modelo TeeJet $8003 \mathrm{E}$, trabalhando a $50 \mathrm{~cm}$ da superfície do alvo. Os produtos químicos foram aplicados em mistura com água em um volume de calda correspondente a $300 \mathrm{~L} / \mathrm{ha}$ e uma pressão de $40 \mathrm{lb} \cdot \mathrm{pol}^{-2}$ através de ar comprimido.

As doses utilizadas variaram de acordo com o herbicida (Tabela 3). Para todos os herbicidas procurou-se utilizar doses que proporcionam no mínimo 50\% de controle da planta daninha $\left(\mathrm{GR}_{\mathbf{5}_{0}}\right)$. Cada herbicida foi avalidado na dose recomendada (tratamento 5) e em doses multiplas, abaixo e acima da recomendada. Após a pulverização com os herbicidas, as plantas foram recolocadas na casa-de-vegetação. 
Tabela 2 - Análise química e granulométrica do substrato utilizado no experimento de casa-de-vegetação.

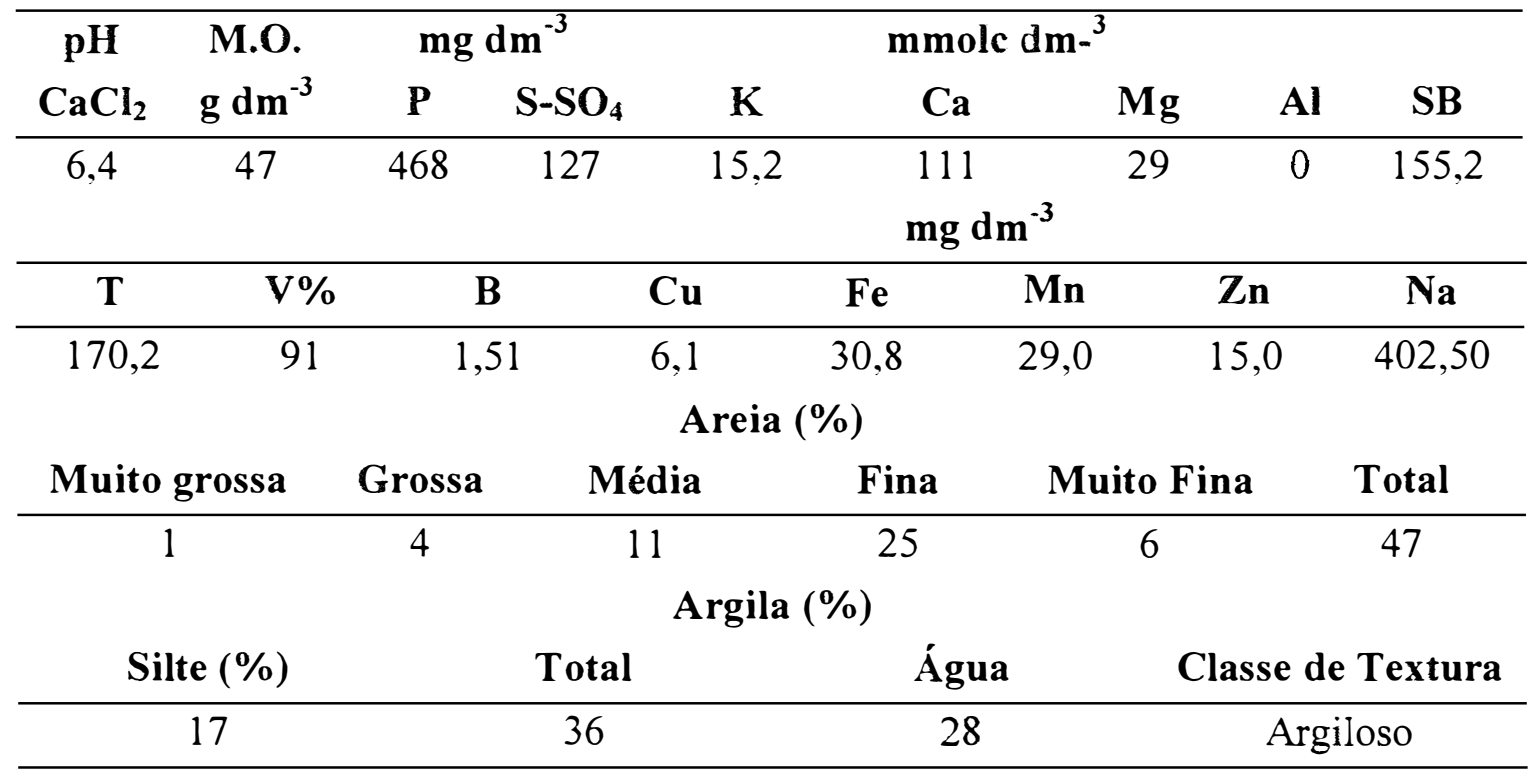

Resultados fornecidos pelo Laboratório de Análise de solo do Departamento de Ciência do Solo - ESALQ/USP.

Tabela 3 - Descrição dos tratamentos utilizados em Bidens pilosa/Bidens subalternans e Amaranthus quitensis, no experimento instalado em condições de casa-de-vegetação.

\section{Herbicidas}

\section{Tratamentos (g p.c./ha)}

\begin{tabular}{ccccccccccc} 
p.c & i.a & $\mathbf{1}$ & $\mathbf{2}$ & $\mathbf{3}$ & $\mathbf{4}$ & $\mathbf{5}$ & $\mathbf{6}$ & $\mathbf{7}$ & $\mathbf{8}$ & $\mathbf{9}$ \\
\hline Classic & chlorimuron ethyl & 6000 & 3000 & 600 & 300 & 60 & 30 & 6 & 3 & 0,0
\end{tabular}

$\begin{array}{llllllllll}\text { Pivot imazethapyr } & 80 & 40 & 8 & 4 & 0,8 & 0,4 & 0,08 & 0,04 & 0,0\end{array}$

\begin{tabular}{llllllllll} 
Sanson nicosulfuron & 30 & 15 & 3 & 1,5 & 0,3 & 0,15 & 0,03 & 0,0015 & 0.0 \\
\hline
\end{tabular}

p.c. $=$ Produto comercial 


\subsubsection{Avaliações}

O efeito dos herbicidas no crescimento das plantas foi determinado aos $7 \mathrm{e}$ 14 dias após o tratamento (DAT), através da porcentagem de controle visual, onde 0 representa nenhum controle e 100 controle total das plantas daninhas. Também foi avaliado, a produção de biomassa verde aos 16 DAT e a biomassa seca, determinada a partir do peso da parte aérea colhido acima da superfície do solo.

\subsubsection{Análise dos dados}

Os dados foram submetidos à análise estatística baseada no modelo de Seefeldt et al. (1995) de dose resposta:

$$
y=\frac{D-C}{1+\exp ^{\left[b\left(\log (x)-\log \left(G R_{50}\right)\right]\right.}+C}
$$

Os dados referentes a Amaranthus quitensis. por não se ajustarem ao modelo acima, foram analisados utilizando-se equações de regressão exponenciais e hiperbólicas.

$$
Y=A^{*} X /(B+X)
$$

$$
Y=\exp \left(A+B^{*} X\right)
$$


3.3. Teste com diferentes herbicidas para manejo de populações $\mathrm{R}$ de Bidens pilosa/Bidens subalternans e Amaranthus quitensis aos herbicidas inibidores da ALS em condições de casa-de-vegetação

\subsubsection{Local}

O experimento foi conduzido em casa-de-vegetação do Departamento de Produção Vegetal, da Escola Superior de Agricultura "Luiz de Queiroz", Universidade de São Paulo, Piracicaba, São Paulo.

\subsubsection{Semeadura e obtenção das plantas}

As plantas resistentes e suscetíveis de Bidens pilosa/Bidens subalternans e Amaranthus quitensis, foram obtidas de sementes coletadas de áreas descritas anteriormente. Estas sementes foram semeadas em copos plásticos de capacidade de $200 \mathrm{ml}$, contendo um substrato a base de solo e material orgânico na proporção 3:1. As análises química e granulométrica deste substrato (Tabela 4) foram realizadas pelo Laboratório de Análise de Solo pertencente ao Departamento de Ciência do Solo da Escola Superior de Agricultura "Luiz de Queiroz". Plantas uniformes e com bom vigor vegetativo foram selecionadas para tratamentos com herbicidas, quando apresentavam de 4 a $6 \mathrm{~cm}$ de altura.

\subsubsection{Tratamentos}

Os tratamentos utilizados, doses de ingrediente ativo e produto comercial por hectare, estão apresentados na Tabela 5. A aplicação foi realizada utilizandose um pulverizador de laboratório, com uma câmara de aplicação fechada e acionado por um motor elétrico. A ponta de pulverização foi do tipo leque modelo TeeJet $8003 \mathrm{E}$, trabalhando a $50 \mathrm{~cm}$ da superfície alvo; os produtos químicos foram aplicados em mistura com água em um volume de calda de 300 L/ha a uma pressão de $40 \mathrm{lb} \cdot$ pol $^{-2}$ através de ar comprimido. No momento da aplicação a temperatura era de $28^{\circ} \mathrm{C}$ e umidade relativa de $80 \%$. 
Tabela 4 - Análise granulométrica e química de macro e alguns micronutrientes presentes na mistura utilizada no experimento em casa-de-vegetação.

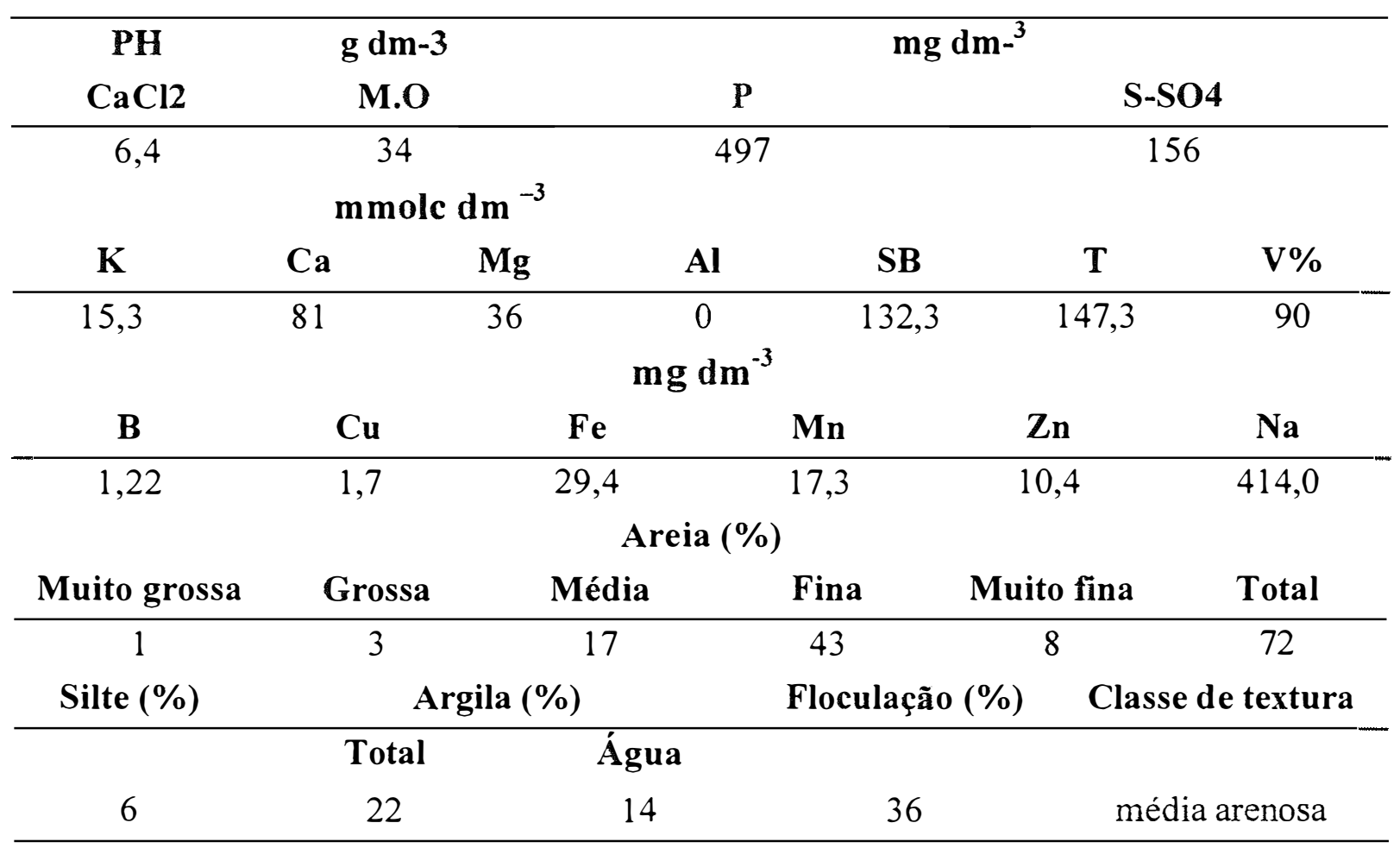

Laboratório de Análise de Solo - Departamento de Ciência do Solo ESALQ/USP. 
Tabela 5 - Tratamentos utilizados em Bidens pilosa/Bidens subalternans e Amaranthus quitensis.

\begin{tabular}{cccccc}
\hline $\begin{array}{c}\text { Trata- } \\
\text { mentos }\end{array}$ & Nome Comum & $\begin{array}{c}\text { Nome } \\
\text { Comercial }\end{array}$ & i.a $^{\mathbf{1}} \cdot \mathbf{g} / \mathbf{h a}$ & $\begin{array}{c}\mathbf{p c}^{2} \mathbf{g} \text { ou } \\
\text { L/ha }\end{array}$ & Adjuvante \\
\hline 1 & chlorimuron-ethyl & Classic & 20 & 80 & Agral 0,2\% v/v \\
\hline 2 & $\begin{array}{c}\text { chlorimuron-ethyl + } \\
\text { fomesafen }\end{array}$ & Classic + Flex & $20+250$ & $80+1,0$ & Agral 0,2\% v/v \\
\hline 3 & $\begin{array}{c}\text { chlorimuron-ethyl + } \\
\text { lactofen }\end{array}$ & Classic + Cobra & $20+192$ & $80+0,8$ & - \\
\hline 4 & $\begin{array}{c}\text { chlorimuron-ethyl + } \\
\text { imazethapyr }\end{array}$ & Classic + Pivot & $20+100$ & $80+1,0$ & - \\
\hline 5 & $\begin{array}{c}\text { chlorimuron-ethyl + } \\
\text { bentazon }\end{array}$ & $\begin{array}{c}\text { Classic }+ \\
\text { Basagran }\end{array}$ & $20+480$ & $80+1,0$ & Agral 0,2\% v/v \\
\hline 6 & lactofen & Cobra & 192 & 0,8 & \\
\hline 7 & fomesafen & Flex & 250 & 1,0 & Agral 0,2\% v/v \\
\hline 8 & bentazon & Basagran & 480 & 1,0 & Agral 0,2\% v/v \\
\hline 9 & testemunha & - & - & - & - \\
\hline
\end{tabular}

1 - Ingrediente ativo

2 - Produto comercial 


\subsubsection{Avaliações}

Foram realizadas avaliações visuais da porcentagem de controle das plantas aos 7 e 14 dias após a aplicação dos herbicidas (DAT). Utilizou-se uma escala visual que variava de 0 para nenhum controle e $100 \%$ para controle total. Aos 14 dias foi determinada a biomassa verde e após secagem em estufa até o peso constante a biomassa seca foi determinada em balança eletrônica com precisão de $0,01 \mathrm{~g}$.

\subsubsection{Análise dos dados}

Os dados foram submetidos à análise de variância para obtenção do valor de F. Sendo este significativo, foram comparadas as médias através do teste Tukey. Para análise estatística os resultados das quatro repetições foram transformados para $\operatorname{arcsen} \sqrt{\% / 100}$

3.4. Análise de crescimento comparativa entre biotipos $\mathrm{R}$ e $\mathrm{S}$ de Bidens pilosa/Bidens subalternans e Amaranthus quitensis

\subsubsection{Local}

O experimento foi conduzido na casa-de-vegetação do Departamento de Produção Vegetal da Escola Superior de Agricultura "Luiz de Queiroz", Piracicaba, São Paulo.

\subsubsection{Material Vegetal}

As sementes de Bidens pilosa/Bidens subalternans foram coletadas em áreas cultivadas com soja que apresentavam problemas de resistência aos herbicidas inibidores da ALS no município de São Gabriel do Oeste, MS, Brasil (população denominada de resistente $\mathrm{R}$ ) e de áreas sem histórico de uso de 
herbicidas inibidores da ALS (população denominada suscetível S). Da mesma forma, as sementes de Amaranthus quitensis foram coletadas nas províncias de Tucumã, de áreas com problemas de resistência aos herbicidas inibidores da enzima ALS e de áreas sem histórico de uso destes herbicidas (populações denominadas, respectivamente, de R (Resistente) e S (Suscetível)). A semeadura foi feita em vasos com capacidade de 1 litro e com $20 \mathrm{~cm}$ de profundidade, utilizando substrato composto por solo e matéria orgânica na proporção 3:1 (análise química e granulométrica, vide Tabela 6) e colocadas em casa-devegetação para seu desenvolvimento.

\subsubsection{Avaliação}

Após 14 dias da semeadura a parte aérea das plantas daninhas que apresentavam o segundo par de folhas verdadeiras foi colhida, sendo pesada em balança de precisão $0,001 \mathrm{~g}$. A área foliar em $\mathrm{cm}^{2}$ foi medida através de aparelho de medição de área foliar (LI-COR - LI-3100) Area Meter. A seguir o material vegetal de cada tratamento foi colocado separadamente em sacos de papel e secos em estufas $\left(60^{\circ} \mathrm{C}\right)$, para determinação da biomassa seca. A parte aérea de cada espécie de planta daninha foi colhida semanalmente até o início do florescimento. utilizando-se quatro vasos dos biotipos $\mathrm{R}$ e quatro dos biotipos $\mathrm{S}$.

\subsubsection{Análise dos Dados}

Os dados foram analizados através da função polinomial assintótica Richards Function (RF).

$$
\log _{e}^{W}=\log _{e}^{A}-\frac{1}{N} * \log _{e}^{\left(1 \pm e^{\left(-k *\left(1-T_{0}\right)\right.}\right)}
$$


Tabela 6 - Análise granulométrica e química de macro e alguns micronutrientes presentes na mistura utilizada no experimento.

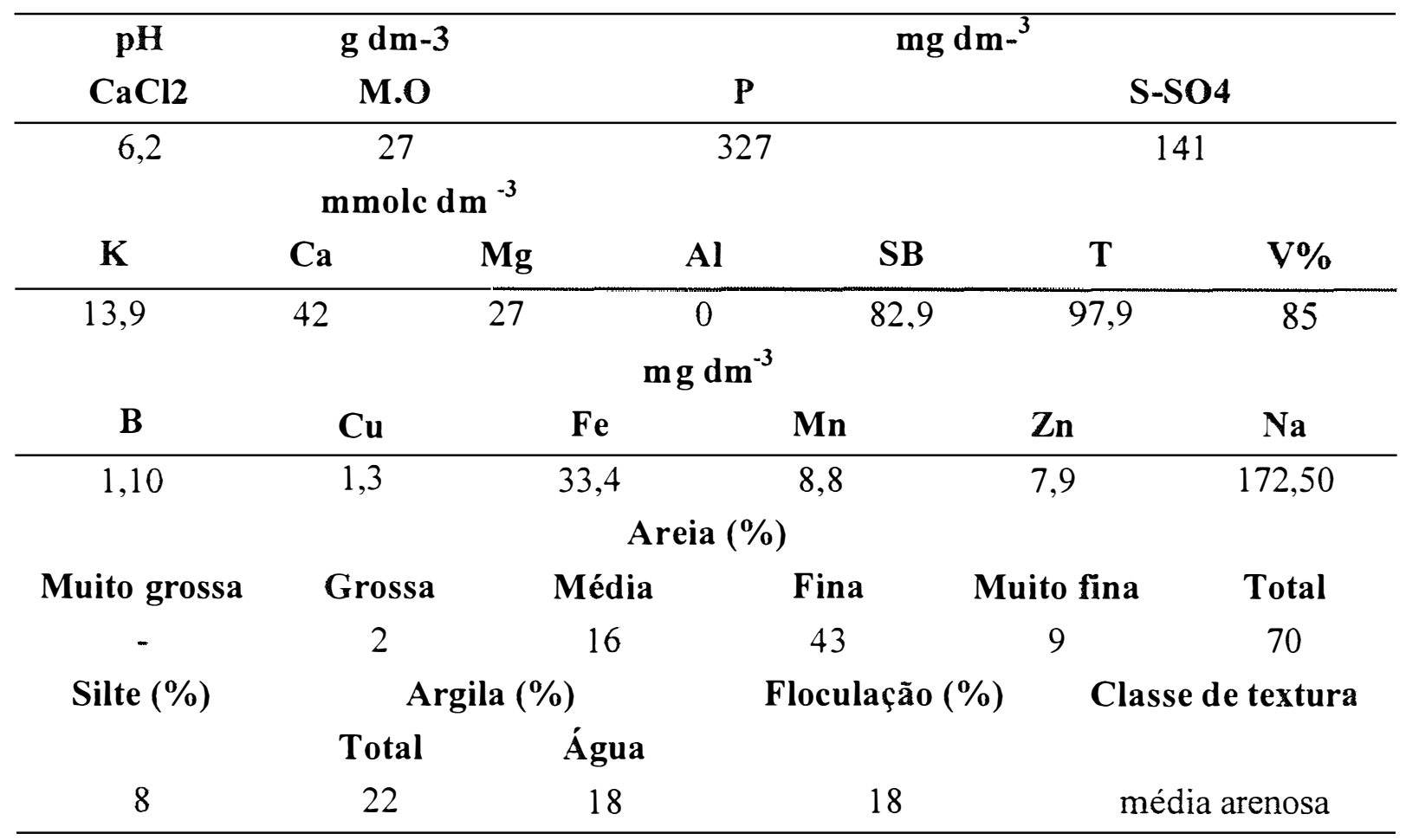




\subsection{Teste rápido da sensibilidade da ALS dos biotipos $\mathrm{R}$ e $\mathrm{S}$ de Bidens} pilosa/Bidens subalternans e Amaranth us quitensis através de biensaio

\subsubsection{Local}

O experimento foi realizado no Centro de Biotecnologia Agrícola (CEBTEC), da Escola Superior de Agricultura "Luiz de Queiroz", Universidade de São Paulo, Piracicaba, São Paulo.

\subsubsection{Material Vegetal}

A metodologia a seguir, foi baseada nos trabalhos de Gerwick (1993), com algumas modificações. Sementes R e $\mathrm{S}$ aos herbicidas inibidores da ALS, das plantas daninhas Bidens pilosa/Bidens subalternans e Amaranthus quitensis, descritas nos experimentos anteriores foram utilizadas neste bioensaio. A semeadura foi realizada separadamente em bandejas $\mathrm{com} 10 \mathrm{~cm}$ de profundidade utilizando-se uma mistura de solo e matéria orgânica. As plantas se desenvolveram em casa-de-vegetação até apresentarem o segundo par de folhas verdadeiras, momento em que foram aplicados os tratamentos.

\subsubsection{Tratamentos}

Os tratamentos e doses utilizadas neste ensaio encontram-se relacionados na Tabela 7. Foram utilizados os herbicidas inibidores da ALS pertencentes aos grupos químicos das sulfoniluréias (chlorimuorn-ethyl) e das imidazolinonas (imazethapyr), e o ácido 1,1-ciclopropanodicarboxílico (CPCA), que é um inibidor da enzima cetoácido reductoisomerase (KARI). Estas enzimas catalizam reações no processo de biossíntese dos aminoácidos valina, leucina e isoleucina. O produtos foram aplicados sobre a parte aérea das plantas com um pulverizador manual. 
Tabela 7 - Tratamentos utilizados em Bidens pilosa/Bidens subalternans e Amaranthus quitensis

\begin{tabular}{cccc}
\hline Tratamentos & Nome Comum & $\begin{array}{c}\text { Nome } \\
\text { Comercial }\end{array}$ & $\begin{array}{c}\mathbf{p c} \mathbf{1} \mathbf{m l} / \mathbf{g} / \mathbf{1 0 0} \mathbf{m l} \\
\mathbf{H}_{\mathbf{2}} \mathbf{O}\end{array}$ \\
\hline 1 & CPCA & CPCA & 0,50 \\
3 & chlorimuron-ethyl + CPCA & Classic +CPCA & $0,20+0,50$ \\
4 & imazethapyr + CPCA & Pivot - CPCA & $0,25+0,50$ \\
5 & testemunha & - & - \\
\hline
\end{tabular}

1. Produto comercial 


\subsubsection{Ensaio com a enzima ALS}

O princípio de funcionamento deste teste baseia-se no fato que durante a biossíntese dos aminoácidos de cadeia ramificada, o substrato é o piruvato que na presença da enzima ALS e de co-fatores, produz acetolactato. Esta reação é então, paralizada pela adição do ácido $\mathrm{H}_{2} \mathrm{SO}_{4}$, que converte acetolactato em acetoína, o qual reage com creatina e naphtol, produzindo um complexo de cor vermelha. Quando é aplicado a mistura do CPCA + herbicida inibidor da ALS, em plantas suscetíveis praticamente não há formação de acetoína, pois a enzima ALS é inibida pelo herbicida, portanto, não há reação colorida. Em plantas suscetíveis o composto vermelho é produzido na presença de CPCA aplicado isoladamente, devido a inibição apenas da enzima KARI, que provoca acumulo de acetolactato. Por outro lado, quando a mistura CPCA + herbicida inibidor da ALS é aplicada em plantas resistentes, há um acumulo de acetolactato, devido a insensibilidade da enzima ao herbicida, havendo, portanto, a formação de um complexo colorido vermelho, devido a reação acetoína + creatina + naftol. Quanto maior a quantidade de acetoína, maior é a atividade da enzima e mais intensa é a cor desenvolvida, proporcionando valores maiores nas leituras de absorbância.

A metodologia a seguir é baseada em Gerwick (1993), com algumas modificações. Após 48 horas da aplicação dos tratamentos foram colhidos os pontos de crescimento das plantas, aproximadamente $5 \mathrm{~g}$ por tratamento. $\mathrm{O}$ material vegetal foi, então, lavado em água corrente e congelado por duas horas. Após congelamento, foi transferido para tubos de ensaio aos quais adicionou-se água três vezes o volume do material colhido, macerando e deixando repousar por uma hora. Após este período, foi removida uma alíquota de $0,5 \mathrm{ml}$ do líquido sobrenadante e transferida para novos tubos, onde foi acrescentado $0,1 \mathrm{ml}$ de $\mathrm{H}_{2} \mathrm{SO}_{4} 5 \%$, deixando em repouso por 15 minutos, adiciona-se, então, $0,5 \mathrm{ml}$ de creatina $0,5 \%$, agitação e repouso por 15 minutos, acrescentando após este período, $0.5 \mathrm{ml}$ de 1 -naphtol $5 \%$, agitação e novo repouso por 60 minutos em 
temperatura ambiente. Após uma hora os tubos foram agitados vigorosamente em Vortex e observada a coloração. A concentração de acetoína formada foi quantificada através de centrifugação por dez minutos em 10.000 g e medida absorbância em $530 \mathrm{~nm}$.

\subsection{Sequenciamento da região de domínio A do gene que confere resistência aos herbicidas inibidores da ALS em Amaranth us quitensis}

\subsubsection{Material Vegetal}

Os biotipos resistentes e suscetíveis de Amaranthus quitensis foram isolados e induzidos a autopolinização. As sementes da geração F1, foram semeadas separadamente em bandejas, com substrato Promix, em casa-devegetação. Quando as plantas apresentavam quatro pares de folhas definitivas foram utilizadas para a extração de DNA.

\subsubsection{Isolamento de DNA total}

A extração de DNA, foi baseada na metodologia de Murray \& Thompson (1980), utilizando-se cerca de $250 \mathrm{mg}$ de folhas jovens das plantas resistentes e suscetíveis de Amaranthus quitensis, maceradas na presença de nitrogênio liquído, rompendo-se assim, as paredes e membranas celulares. Na segunda etapa, o tecido vegetal foi ressuspenso em um tampão de extração CTAB-Sarcosyl, visando a solubilização de membranas lipoproteícas e denaturação de proteínas enquanto o DNA foi protegido da ação de enzimas de degradação.

A separação e purificação do DNA das proteínas, lípidios e de outros componentes celulares foi obtida através do tampão de precipitação CTAB (1\% CTAB, $1 \mathrm{M}$ Tris - $\mathrm{HCl}$ pH 7,5 e 0,5M EDTA). A precipitação do DNA foi feita com a adição de $1 \mathrm{ml}$ de etanol $100 \%$ : após ser lavado com $500 \mu$ de etanol $70 \%$ 
para retirar o alto teor de sal do DNA sendo também realizado um tratamento com RNAse. Finalmente o DNA foi ressuspeso em um volume final de $25 \mu \mathrm{lde}$ água mili-Q esterelizada.

\subsubsection{Amplificação de fragmento do gene ALS}

A amplificação de fragmentos do gene ALS em biotipos resistentes e suscetiveis Amaranthus quitensis, foram realizadas utilizando-se primers obtidos a partir de sequências completas da enzima ALS de várias plantas como: Arabidopsis thaliana, Kochia scoparia, Nicotiana tabacccum, Xanthium sp e Amaranthus rudis, analizados através do site NCBI (http://www.ncbi.nlm.nih.gov). Após a análise de homologia de nucleotídeos as regiões mais conservadas que flanqueiam a região de Domínio A do gene als, foram escolhidas para a síntese dos primers abaixo, procurando a amplificação de segmento de DNA para o sequenciamento. Foram sintetizados seis primers sem sítios de restrição:

\section{ALS P1}

5'GT(A/C/G/T)TT((C/T)GC(G/T)TA(C/T)CC(A/T)GG(A/C/T)GG(A/C/T)GC 3' ALS P2

$5^{\prime} \mathrm{CC}(\mathrm{A} / \mathrm{T}) \mathrm{CG}(\mathrm{A} / \mathrm{C} / \mathrm{T}) \mathrm{CA}(\mathrm{A} / \mathrm{T}) \mathrm{GA}(\mathrm{A} / \mathrm{G}) \mathrm{CA}(\mathrm{A} / \mathrm{G}) \mathrm{GG}(\mathrm{C} / \mathrm{G} / \mathrm{T}) \mathrm{G}$ 3'

ALS P3

5' GG(A/G/T)ATGCA(C/T)GG(G/T)AC(C/G/T)GT(G/T)TA(C/T) 3'

ALS P4

5' C(A/G)TA(A/C)AC(A/C/G)GT(A/C)CC(A/G)TGCAT(A/C/T)CC 3'

ALS P5

5' CCATC(A/C/G/T)CC(A/G)TC(A/G)AT(A/GA/G)C(A/C/T)AC(A/C/T)AC 3'

ALS P6

5' CAT(A/C/G)GGCA(A/G)(A/C)AC(A/G)TG(C/T)TC 3' 
Foram testados combinações destes primes como se segue:

\begin{tabular}{cc}
\hline Combinações & Fragmentos esperados \\
P1-P4 & $384 \mathrm{pb}$ \\
P2-P4 & $612 \mathrm{pb}$ \\
P2-P5 & $780 \mathrm{pb}$ \\
P1-P5 & $1227 \mathrm{pb}$ \\
\hline
\end{tabular}

As reações de PCR foram preparadas utilizando-se 100ng do DNA total, 10pmoles dos primers, 0,5 unidades de Taq DNA Polymerase (Promega 18038018), 1,5 mM $\mathrm{MgCl}_{2}$ e 200nmoles dNTPs e tampão de reação de PCR que acompanha a enzima.

O termocilador foi programado como segue:

Incubação: $94^{\circ} \mathrm{C} 1,5$ minutos

35 ciclos de:

$94^{\circ} \mathrm{C} 2$ minutos (denaturação; $55^{\circ} \mathrm{C} 1,5$ minutos (anelamento);

$72^{\circ} \mathrm{C} 2$ minutos (alongamento)

Temperatura final: $4^{\circ} \mathrm{C}$

Foram testados diferentes temperaturas de anelamento $(40,45,48,50,52 \mathrm{e}$ $\left.55^{\circ} \mathrm{C}\right)$.

\subsubsection{Eletroforese do PCR}

O produto do PCR $(50 \mu 1)$ foi colocado em $0,8 \%$ gel de agarose para separação dos fragmentos de PCR de acordo com o tamanho e carga elétrica líquida. A banda de tamanho esperado. correspondente a combinação de primers utilizados foi isolada e purificada através do Kit Qiaex sendo o DNA ressuspendido em $20 \mu 1$ de água.

\subsubsection{Clonagem de fragmento de PCR em vetor pUC 18 (Sure Clone)}

Para a clonagem do fragmento de interesse no vetor pUC18 foi utilizado o kit Sure Clone Ligation Kit, da Pharmacia. Neste procedimento, inicialmente foi 
necessário o reparo das pontas 5' e 3' dos fragmentos obtidos na amplificação. A presença da enzima Klenow polimerase I remove as bases que estão em fita simples na região 3' do fragmento de PCR. A enzima T4 polinucleotidio quinase faz a fosforilação das pontas. Foi utilizado $8 \mu \mathrm{l}$ de DNA purificado para o reparo das pontas (blunting), sendo em seguida feito a purificação do fragmeto através da coluna "microspin" recuperando-se cerca de $10 \mu$ l para a reação de ligação do fragmento no sítio de restrição SmaI do vetor que possui extremidade lisa. A reação de ligação foi preparada e mantida por 4 horas a $16^{\circ} \mathrm{C}$ sendo em seguida feito a transformação em linhagem $\mathrm{DH} 5 \alpha$ de bactérias competentes. Foi feito o plaqueamento em meio agar + ampicilina e após o crescimento das colônias, foi feita a inoculação das mesmas em meio LB + ampicilina. Após isolamento de DNA plasmidial contendo o fragmento clonado, através da minipreparação de DNA, foi feito o sequenciamento utilizando os primers reverse e forward.

As sequências obtidas foram analizadas através do programa BLAST da NCBI para estudar o grau de homologia com a sequência do gene da enzima ALS de diferentes organismos já sequenciados e armazenados no genbank. 


\section{RESULTADOS E DISCUSSÕES}

\subsection{Avaliação da sensibilidade de biotipos resistentes de Bidens pilosa/Bidens subalternans aos herbicidas inibidores da ALS e a herbicidas com outros mecanismos de ação (herbicidas alternativos) em condições de campo}

De acordo com a Tabela 8, onde encontram-se representados os resultados da porcentagem de controle da planta daninha Bidens pilosa/Bidens subalternans observa-se que os tratamentos com os herbicidas inibidores da ALS isolados (chlorimuron-etyl ou imazethapyr) ou em mistura entre si, não controlaram a planta daninha satisfatóriamente, sendo que o tratamento com o herbicida imazethapyr apresentou resultado estatísticamente semelhante a testemunha.

Os resultados obtidos comprovam que, nesta área cultivada com soja, houve a seleção de um biotipo resistente de picão-preto aos herbicidas inibidores da ALS. A aplicação destes herbicidas para o controle das plantas daninhas do tipo folha larga durante oito anos, aumentou a frequência de alelos resistentes a estes herbicidas, atingindo a frequência crítica, ou seja, os índices de controle são considerados insatisfatórios.

Os herbicidas inibidores da ALS, quando em mistura com herbicidas alternativos; fomesafen, lactofen (inibidores da PROTOX) e bentazon (inibidores do FSII- P680), apresentaram maior eficiência no controle de picão-preto, porém, estes resultados foram menores que o esperado, pois a dose utilizada no experimento foi menor que a recomendada. 
Tabela 8- Controle da planta daninha Bidens pilosa/Bidens subalternans, em experimento de campo aos 14 e 21 dias após a aplicação dos herbicidas (DAT).

\begin{tabular}{lcccc}
\hline \multirow{2}{*}{ Tratamentos } & \multicolumn{4}{c}{ Doses } \\
& i.a & p.c & $\mathbf{1 4}$ & $\mathbf{2 1}$ \\
\cline { 2 - 5 } & 20 & 80 & $42,5 \mathrm{c}$ & $21,6 \mathrm{c}$ \\
\hline - Chlorimuron ethyl & $12,5+120$ & $50+0,5$ & $53,8 \mathrm{bc}$ & $63,8 \mathrm{~b}$ \\
2-Chlorimuron ethyl + lactofen & $12,5+150$ & $50+0,6$ & $72,5 \mathrm{a}$ & $72,5 \mathrm{ab}$ \\
3-Chlorimuron ethyl + fomesafen & $12,5+384$ & $50+0,8$ & $47,5 \mathrm{c}$ & $67,8 \mathrm{~b}$ \\
4- Chlorimuron ethyl + bentazon & $12,5+50$ & $50+0,5$ & $37,5 \mathrm{c}$ & $17,2 \mathrm{c}$ \\
5- Chlorimuron ethyl + imazethapyr & 192 & 0,8 & $80,0 \mathrm{a}$ & $80,5 \mathrm{ab}$ \\
6- Lactofen & 225 & 0,9 & $82,6 \mathrm{a}$ & $85,3 \mathrm{a}$ \\
7- Fomesafen & 480 & 1,0 & $66,7 \mathrm{ab}$ & $72,6 \mathrm{ab}$ \\
8- Bentazon & 100 & 1,0 & $0,3 \mathrm{~d}$ & $0,0 \mathrm{~d}$ \\
9- Imazethapyr & 0 & 0 & $0,0 \mathrm{~d}$ & $0,0 \mathrm{~d}$ \\
10- Testemunha & & & $107,16^{* *}$ & $127,33^{* *}$ \\
\hline $\boldsymbol{F}$ & & & 10,71 & 11,18 \\
C.V (\%) & & & 10,80 & 11,13 \\
D.M.S (\%) & & & &
\end{tabular}

$\mathbf{i} . \mathbf{a}=$ Ingrediente ativo; $\mathbf{p . c} .=$ Produto comercial ** = Teste F significativo ao nível de $1 \%$ de probabilidade obs: Média acompanhadas de letras iguais na mesma coluna não diferem estatisticamente entre si através do teste de Tukey ao nível de 5\% de probabilidade 
Sempre é utilizado, nas misturas, herbicidas com diferentes mecanismos de ação, pois se um biotipo for resistente a um dos produtos da mistura, ele poderá ser eliminado pelo outro ingrediente ativo da mistura (Powles \& Holtum, 1994). Esta estratégia pode retardar o aparecimento de resistência, pois se a frequência inicial de alelos para a resistência é de $10^{-6}$ para cada um dos herbicidas envolvidos na mistura, a chance de que uma única planta tenha alelos múltiplos de resistência para ambos os herbicidas da mistura será de aproximadamente $10^{-12}$.

É importante ressaltar que a mistura de herbicidas de diferentes mecanismos de ação, é útil para plantas autógamas, pois, no caso de polinização cruzada, plantas que apresentam alelos individuais conferindo resistência poderão se cruzar e assim aumentar a probabilidade de progênie resistente a ambos os herbicidas (Gould, 1995).

Os herbicidas alternativos, utilizados isoladamente, apresentaram um controle bastante eficiente da população resistente de Bidens pilosa/Bidens subalternans, evidenciando, assim, a importância de se evitar o uso contínuo, na mesma área, dos mesmos herbicidas ou de herbicidas com o mesmo mecanismo de ação, através da rotação de herbicidas e da rotação de culturas. Christoffoleti et al. (1994) afirmam que a rotação de culturas permite, também, a utilização de diferentes herbicidas, colaborando, assim, na redução da pressão de seleção sobre o agroecossistema.

O Comitê Brasileiro de Resistência de Plantas aos Herbicidas (CBRPH), recomenda para a prevenção e manejo da resistência, o manejo integrado de plantas daninhas, mantendo um ambiente desfavorável para estas plantas, mediante o emprego isolado ou combinado dos métodos biológicos, culturais, mecânicos, químicos e fĩsicos de controle. O objetivo básico é a redução da infestação de plantas daninhas a níveis que não interfiram na produtividade econômica das culturas. 


\subsection{Testes com diferentes herbicidas para manejo de populações $\mathrm{R}$ de Bidens pilosa/Bidens subalternans e Amaranthus quitensis aos herbicidas inibidores da ALS em condições de casa-de-vegetação}

O controle alternativo dos biotipos resistentes e suscetíveis das plantas daninhas Bidens pilosa/Bidens subalternans e Amaranthus quitensis, com diversos herbicidas, pode ser analisado nas Tabelas 9 a 12. Os herbicidas inibidores da ALS, imazethapyr e chlorimuron-ethyl quando aplicados sozinhos ou em mistura entre si, não foram eficientes, como esperado, no controle das populações resistentes das duas espécies, porém, controlaram satisfatóriamente as populações suscetíveis. De acordo, com Lorenzi (1994), os herbicidas chlorimuron-ethyl e imazethapyr são recomendados para o controle destas plantas daninhas em pós-emegência precoce na cultura da soja.

Quando se aplica a mistura de herbicidas inibidores da ALS com os herbicidas alternativos, como lactofen, fomesafen e bentazon, o controle se mostrou eficiente tanto nas populações suscetíveis como nas resistentes, resultado semelhante do experimento de campo (Tabela 8). Do mesmo modo, os herbicidas alternativos utilizados sozinhos foram satisfatórios no controle e reduziram substancialmente a produção de fitomassa em ambos biotipos das duas espécies estudadas. Embora não diferindo estatísticamente os tratamentos com lactofen, chlorimuron-ethyl + lactofen e chlorimuron-ethyl + fomesafen, foram os mais eficientes no controle de Bidens pilosa/Bidens subalternans e Amaranthus quitensis.

Segundo, o HRAC (Herbicide Resistance Action Committee), dentre as estratégias de prevenção da resistência, existe a rotação de culturas que permite a rotação herbicidas e misturas de herbicidas com diferentes mecanismos de ação e que apresentem eficácia similar no controle da planta daninha alvo. 
Tabela 9 - Porcentagem de controle dos biotipos resistentes e suscetíveis de Bidens pilosa/Bidens subalternans aos 7 e 14 DAT, em casa-devegetação.

\begin{tabular}{lccccc}
\hline \multirow{2}{*}{ Tratamentos } & Doses & \multicolumn{2}{c}{$\begin{array}{c}\text { Biotipo } \\
\text { Resistente }\end{array}$} & \multicolumn{2}{c}{$\begin{array}{c}\text { Biotipo } \\
\text { Suscetível }\end{array}$} \\
\cline { 2 - 6 } & g i.a/ha & 7 DAT & 14 DAT & 7 DAT & 14 DAT \\
\hline 1-Chlorimuron-ethyl & 20 & $20,17 \mathrm{~b}$ & $39,10 \mathrm{~b}$ & $53,77 \mathrm{a}$ & $75,05 \mathrm{a}$ \\
2-Chlorimuron-ethyl + fomesafen & $20+250$ & $56,94 \mathrm{a}$ & $78,60 \mathrm{a}$ & $78,74 \mathrm{a}$ & $83,53 \mathrm{a}$ \\
3-Chlorimuron-ethyl + lactofen & $20+192$ & $82,50 \mathrm{a}$ & $86,76 \mathrm{a}$ & $75,05 \mathrm{a}$ & $90,00 \mathrm{a}$ \\
4-Chlorimuron-ethyl + imazethapyr & $20+100$ & $9,69 \mathrm{~b}$ & $31,39 \mathrm{~b}$ & $63,43 \mathrm{a}$ & $76,17 \mathrm{a}$ \\
5-Chlorimuron-ethyl + bentazon & $20+480$ & $67,25 \mathrm{a}$ & $84,30 \mathrm{a}$ & $63,83 \mathrm{a}$ & $84,30 \mathrm{a}$ \\
6- Lactofen & 192 & $86,76 \mathrm{a}$ & $90,00 \mathrm{a}$ & $82,16 \mathrm{a}$ & $86,76 \mathrm{a}$ \\
7- Fomesafen & 250 & $71,56 \mathrm{a}$ & $82,16 \mathrm{a}$ & $72,10 \mathrm{a}$ & $78,93 \mathrm{a}$ \\
8-Bentazon & 480 & $74,14 \mathrm{a}$ & $78,75 \mathrm{a}$ & $78,74 \mathrm{a}$ & $78,75 \mathrm{a}$ \\
9- Testemunha & - & $0,00 \mathrm{~b}$ & $0,00 \mathrm{~b}$ & $0,00 \mathrm{~b}$ & $0,00 \mathrm{~b}$ \\
\hline $\boldsymbol{F}$ & & $28,00 * *$ & $35,89 * *$ & $30,00 * *$ & $42,05 * *$ \\
C.V (\%) & & 15,00 & 20,37 & 23,08 & 17,22 \\
D.M.S (\%) & & 16,54 & 18,47 & 22,45 & 19,80 \\
\hline
\end{tabular}

obs: Médias acompanhadas de letras iguais na mesma coluna não diferem estatísticamente entre si através do teste de Tukey ao nível de 5\% de propabilidade.

$* *=$ Teste $\mathrm{F}$ significativo ao nível de $1 \%$ de probabilidade 
Tabela 10 - Produção de biomassa verde aos 16 DAT e biomassa seca dos biotipos R e S de Bidens pilosa/Bidens subalternans.

\begin{tabular}{|c|c|c|c|c|c|}
\hline \multirow[b]{2}{*}{ Tratamentos } & \multirow{2}{*}{$\begin{array}{c}\text { Doses } \\
\text { g i.a/ha }\end{array}$} & \multicolumn{2}{|c|}{ Biotipo Resistente } & \multicolumn{2}{|c|}{ Biotipo Suscetível } \\
\hline & & $\begin{array}{c}\text { Biomassa } \\
\text { verde }\end{array}$ & $\begin{array}{c}\text { Biomassa } \\
\text { seca }\end{array}$ & $\begin{array}{c}\text { Biomassa } \\
\text { verde }\end{array}$ & $\begin{array}{c}\text { Biomassa } \\
\text { seca }\end{array}$ \\
\hline 1 -Chlorimuron-ethyl & 20 & $0,29 \mathrm{a}$ & $0,135 \mathrm{ab}$ & $0,06 \mathrm{~b}$ & $0,032 \mathrm{~b}$ \\
\hline 2 - Chlorimuron-ethyl + fomesafen & $20+250$ & $0,035 \mathrm{c}$ & $0,017 \mathrm{~d}$ & $0,03 \mathrm{~b}$ & $0,012 b$ \\
\hline 3 - Chlorimuron-ethyl + lactofen & $20+192$ & $0,02 \mathrm{c}$ & $0,010 \mathrm{~d}$ & $0.035 \mathrm{~b}$ & $0,010 \mathrm{~b}$ \\
\hline 4-Chlorimuron-ethyl + imazethapyr & $20+100$ & $0,16 b$ & 0,09 bc & $0,045 \mathrm{~b}$ & $0,015 b$ \\
\hline 5 -Chlorimuron-ethyl + bentazon & $20+480$ & $0,032 c$ & $0,030 \mathrm{~cd}$ & $0,030 \mathrm{~b}$ & $0,015 b$ \\
\hline 6 - Lactofen & 192 & $0,02 \mathrm{c}$ & $0,012 \mathrm{~d}$ & $0,017 b$ & $0,010 \mathrm{~b}$ \\
\hline 7-Fomesafen & 250 & $0,02 \mathrm{c}$ & $0,0125 \mathrm{~d}$ & $0,03 \mathrm{~b}$ & $0,020 \mathrm{~b}$ \\
\hline 8 - Bentazon & 480 & $0,04 \mathrm{c}$ & $0,020 \mathrm{~d}$ & $0,03 \mathrm{~b}$ & $0,015 \mathrm{~b}$ \\
\hline 9 - Testemunha & 0 & $0,32 \mathrm{a}$ & $0,175 \mathrm{a}$ & $0,30 \mathrm{a}$ & $0,152 \mathrm{a}$ \\
\hline$F$ & & $18,24 * *$ & $32,05 * *$ & $20,01 * *$ & $23,49 * *$ \\
\hline$C V \%$ & & 18,56 & 36,04 & 30,00 & 41,70 \\
\hline$D M S(\%)$ & & 0,058 & 0,038 & 0,068 & 0,047 \\
\hline
\end{tabular}

obs: Médias acompanhadas de letras iguais na mesma coluna não diferem estatísticamente entre si através do teste de Tukey ao nível de 5\% de propabilidade.

** = Teste $\mathrm{F}$ significativo ao nível de $1 \%$ de probabilidade 
Tabela 11 - Porcentagem de controle dos biotipos de Amaranthus quitensis resistentes e suscetíveis aos 7 e 14 DAT, em casa-de-vegetação.

\begin{tabular}{|c|c|c|c|c|c|}
\hline \multirow[t]{2}{*}{ Tratamentos } & \multirow{2}{*}{$\begin{array}{c}\text { Doses } \\
\text { g i.a/ha }\end{array}$} & \multicolumn{2}{|c|}{$\begin{array}{c}\text { Biotipo } \\
\text { Resistente }\end{array}$} & \multicolumn{2}{|c|}{$\begin{array}{c}\text { Biotipo } \\
\text { Suscetível }\end{array}$} \\
\hline & & 7 DAT & 14 DAT & 7 DAT & 14 DAT \\
\hline$I$ - Chlorimuron-ethyl & 20 & $12,92 \mathrm{~cd}$ & $11,09 \mathrm{~b}$ & $62,14 \mathrm{a}$ & $78,93 \mathrm{a}$ \\
\hline 2 - Chlorimuron-ethyl + fomesafen & $20+250$ & $78,46 \mathrm{a}$ & $90,00 \mathrm{a}$ & $62,94 \mathrm{a}$ & $74,14 \mathrm{a}$ \\
\hline 3-Chlorimuron-ethyl + lactofen & $20+192$ & $82,16 \mathrm{a}$ & $83,53 \mathrm{a}$ & $76,71 \mathrm{a}$ & $90,00 \mathrm{a}$ \\
\hline 4-Chlorimuron-ethyl + imazethapyr & $20+100$ & $33,75 \mathrm{bc}$ & $18,14 \mathrm{~b}$ & $69,82 \mathrm{a}$ & $68,59 \mathrm{a}$ \\
\hline 5 - Chlorimuron-ethyl + bentazon & $20+480$ & $80,78 \mathrm{a}$ & $63,80 \mathrm{a}$ & $63,61 \mathrm{a}$ & $65,46 \mathrm{a}$ \\
\hline 6- Lactofen & 192 & 76,17 a & $85,54 \mathrm{a}$ & $86,76 \mathrm{a}$ & $82,16 \mathrm{a}$ \\
\hline 7 - Fomesafen & 250 & $78,93 \mathrm{a}$ & 78,75 a & $78,74 \mathrm{a}$ & $79,69 \mathrm{a}$ \\
\hline 8 - Bentazon & 480 & $53,84 \mathrm{ab}$ & $58,04 \mathrm{ab}$ & $58,04 \mathrm{ab}$ & $58,45 \mathrm{a}$ \\
\hline 9 - Testemunha & 0 & $0,00 \mathrm{~d}$ & $0,00 \mathrm{~b}$ & $0,00 \mathrm{~b}$ & $0,00 \mathrm{~b}$ \\
\hline$F$ & & $12,48^{* *}$ & $20,15^{* *}$ & $26,92^{* *}$ & $24,12 * *$ \\
\hline $\mathrm{CV} \%$ & & 24,49 & 18,49 & 24,60 & 26,70 \\
\hline $\operatorname{DMS}(\%)$ & & 19.37 & 15,04 & 23,27 & 25,94 \\
\hline
\end{tabular}

obs: Médias acompanhadas de letras iguais na mesma coluna não diferem estatísticamente entre si através do teste de Tukey ao nível de $5 \%$ de propabilidade.

$* *=$ Teste $\mathrm{F}$ significativo ao nível de $1 \%$ de probabilidade 
Tabela 12 - Produção de biomassa verde aos 16 DAT e biomassa seca dos biotipos resistentes e suscetiveis de Amaranthus quitensis.

\begin{tabular}{|c|c|c|c|c|c|}
\hline \multirow[b]{2}{*}{ Tratamentos } & \multirow{2}{*}{$\begin{array}{c}\text { Doses } \\
\text { g i.a/ha }\end{array}$} & \multicolumn{2}{|c|}{ Biotipo Resistente } & \multicolumn{2}{|c|}{ Biotipo Suscetível } \\
\hline & & $\begin{array}{c}\text { Biomassa } \\
\text { verde }\end{array}$ & $\begin{array}{c}\text { Biomassa } \\
\text { seca }\end{array}$ & $\begin{array}{c}\text { Biomassa } \\
\text { verde }\end{array}$ & $\begin{array}{c}\text { Biomassa } \\
\text { seca }\end{array}$ \\
\hline l- Chlorimuron-ethyl & 20 & $0,412 b$ & $0,165 \mathrm{~b}$ & $0,112 \mathrm{~b}$ & $0,015 \mathrm{~b}$ \\
\hline 2 - Chlorimuron-ethyl + fomesafen & $20+250$ & $0,052 \mathrm{c}$ & $0,020 \mathrm{~d}$ & $0,040 \mathrm{~b}$ & $0,017 b$ \\
\hline 3 - Chlorimuron-ethyl + lactofen & $20+192$ & $0,025 \mathrm{c}$ & $0,012 \mathrm{~d}$ & $0,032 b$ & $0.015 b$ \\
\hline 4 - Chlorimuron-ethyl + imazethapyr & $20+100$ & $0,247 \mathrm{~b}$ & $0,102 \mathrm{bc}$ & $0,040 \mathrm{~b}$ & $0,017 b$ \\
\hline 5 - Chlorimuron-ethyl + bentazon & $20+480$ & $0,057 \mathrm{c}$ & $0,027 \mathrm{~cd}$ & $0,070 \mathrm{~b}$ & $0,037 \mathrm{~b}$ \\
\hline 6 - Lactofen & 192 & $0,032 \mathrm{c}$ & $0,010 \mathrm{~d}$ & $0,020 \mathrm{~b}$ & $0,012 b$ \\
\hline 7-Fomesafen & 250 & $0,027 \mathrm{c}$ & $0,015 \mathrm{~d}$ & $0,035 \mathrm{~b}$ & $0,017 b$ \\
\hline 8 - Bentazon & 480 & $0,037 \mathrm{c}$ & $0,032 \mathrm{~cd}$ & $0,090 \mathrm{~b}$ & $0,050 \mathrm{~b}$ \\
\hline 9 - Testemunha & 0 & $0,610 \mathrm{a}$ & $0,290 \mathrm{a}$ & $0,590 \mathrm{a}$ & $0,297 \mathrm{a}$ \\
\hline$F$ & & $39,48 * *$ & $41,87 * *$ & $52,11 * *$ & $53,45 * *$ \\
\hline$C V \%$ & & 23.51 & 25,79 & 51,4 & 44,18 \\
\hline$D M S(\%)$ & & 0,048 & 0,064 & 0,11 & 0.05 \\
\hline
\end{tabular}

obs: Médias acompanhadas de letras iguais na mesma coluna não diferem estatísticamente entre si através do teste de Tukey ao nível de 5\% de propabilidade.

** = Teste $\mathrm{F}$ significativo ao nível de $1 \%$ de probabilidade 
De acordo com Powles \& Holtum (1994), quando os biotipos apresentam resistência a apenas uma classe de herbicida, o sucesso no manejo da resistência, pode ser alcançado através de herbicidas alternativos. Contudo esta é uma estratégia de sucesso a curto prazo, pois se forem utilizados intensivamente, há o risco de se desenvolver resistência também para estes herbicidas alternativos.

A resistência é um fato crescente em todas as áreas agrícolas e pode ocorrer com qualquer classe de herbicidas, desde que incorretamente manejado, sendo que, na maioria dos casos, o aparecimento dos biotipos resistentes está associado ao uso repetido do mesmo herbicida ou de herbicidas com o mesmo mecanismo de ação, sempre associado à monocultura. É necessário, portanto, o treinamento e divulgação de estratégias que previnam e retardem o aparecimento de resistência, como o uso de herbicidas alternativos. a mistura ou sequência de herbicidas com diferentes mecanismos de ação e o manejo de herbicidas.

\subsection{Análise de crescimento comparativa entre biotipos $\mathrm{R}$ e $\mathrm{S}$ de Bidens pilosa/Bidens subalternans e Amaranthus quitensis}

A taxa de crescimento dos biotipos resistentes e suscetíveis de Bidens pilosa/Bidens subalternans, na ausência de herbicidas inibidores da ALS, pode ser analisada através da biomassa verde e seca, representadas nas Figuras 01 e 02, respectivamente, e através da área foliar representada na Figura 03. 


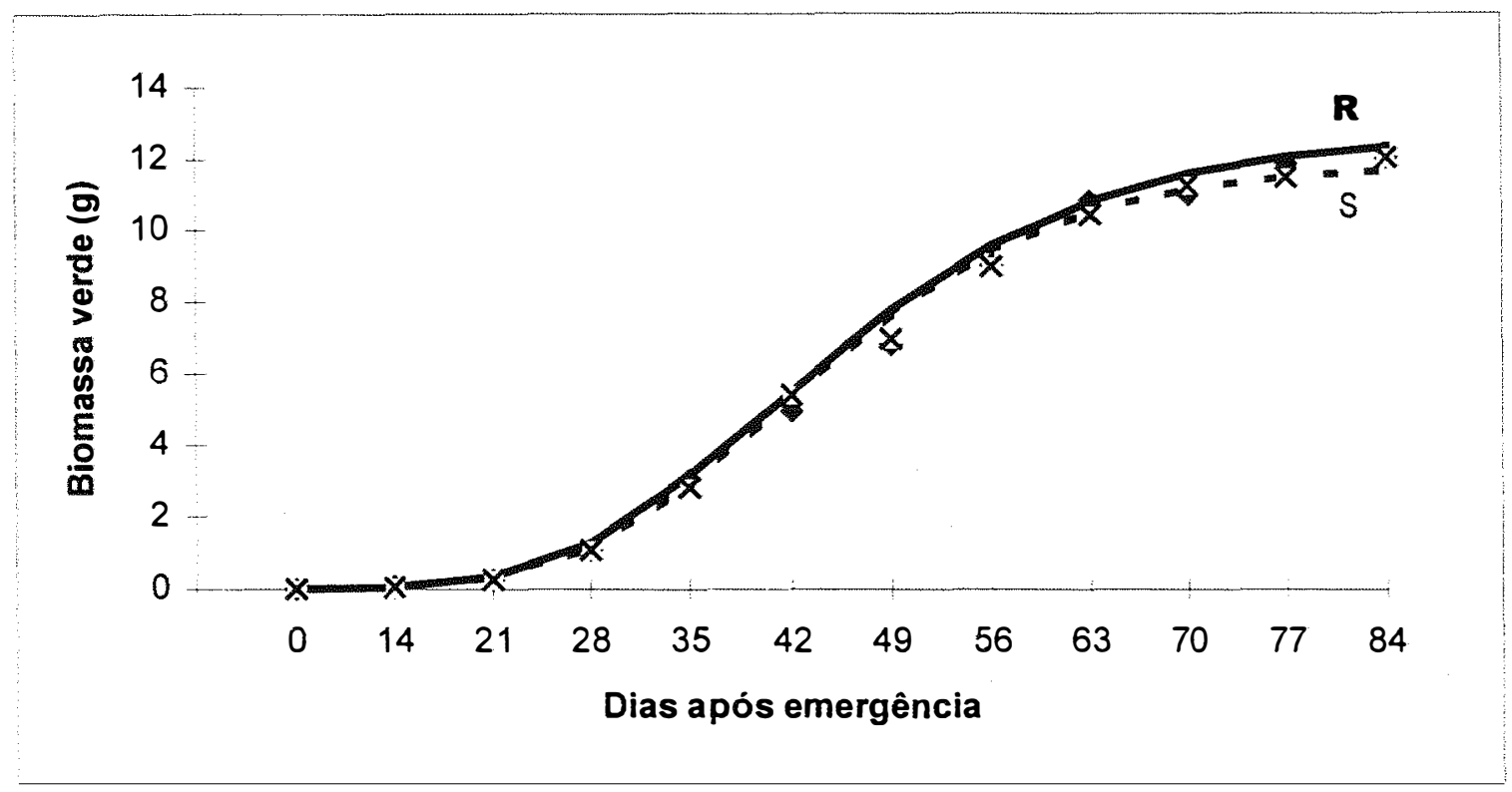

Figura 01 - Curvas de produção de biomassa verde pelos biotipos resistentes e suscetíveis de B. pilosa/B.subalternans .

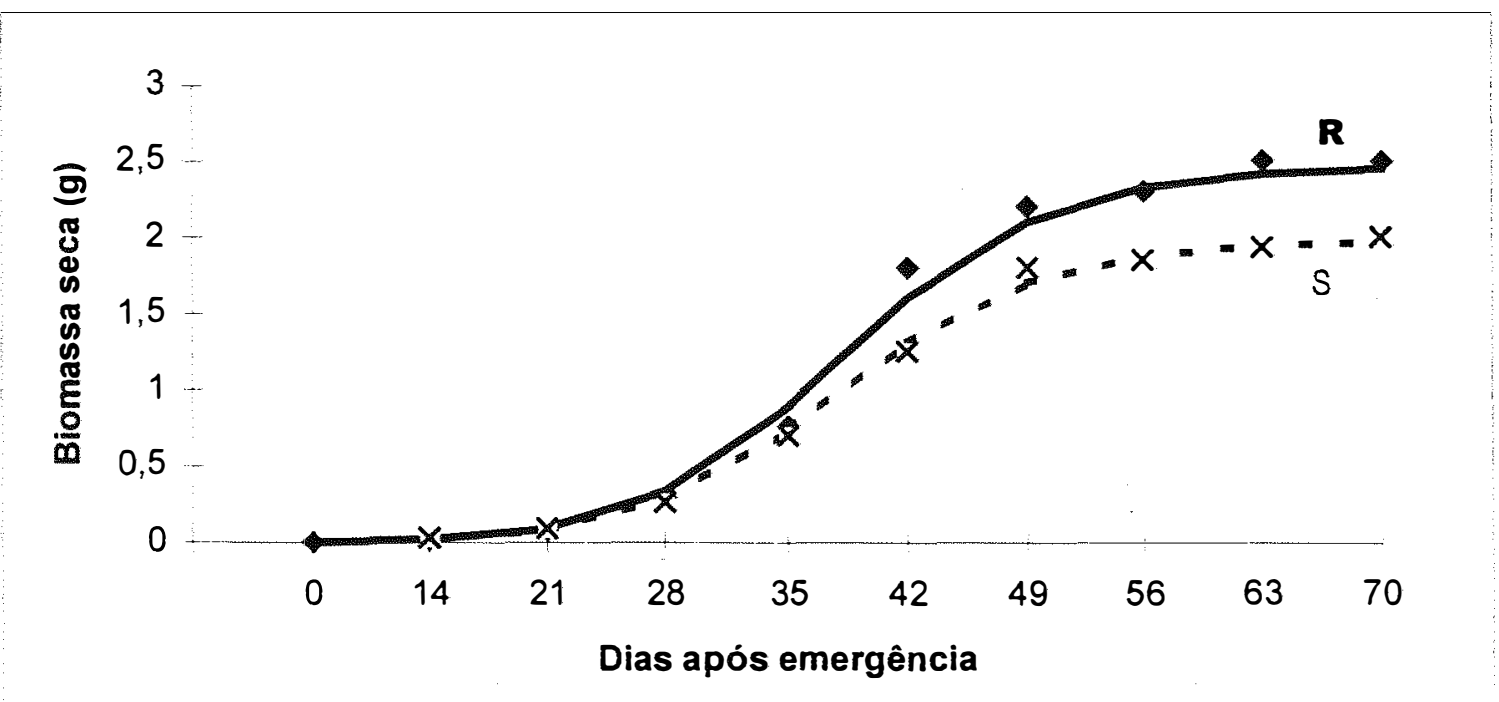

Figura 02 - Curvas de produção de biomassa seca pelos biotipos resistentes e suscetíveis de $B$. pilosa/B. subalternans. 
Os biotipos resistentes de Bidens pilosa/Bidens subalternans, apresentaram uma biomassa vegetal relativamente maior dos que os biotipos suscetíveis, a partir dos 21 dias, porém essa diferança não foi significativa, sendo os parâmetros estudados, A (assintótica máxima no tempo infinito); $\mathrm{N}$ (posição do ponto de inflexão); K (taxa na qual o A é atingindo); To (tempo onde a curva é superior a zero), relativamente iguais entre os biotipos (Tabela 13). Por outro lado, observando-se a Figura 03, pode-se notar que o biotipo suscetível apresentou uma área foliar superior ao biotipo resistente, havendo diferanças entre os parâmetros, o que pode indicar uma habilidade competitiva favorável ao biotipo suscetível.

Os resultados de biomassa verde e seca dos biotipos de Amaranthus quitensis indicam que o biotipo $\mathrm{R}$ produz um acumulo significativamente maior de biomassa que o biotipo S (Figuras 04 e 05). No entanto, as plantas S são mais folhosas, conforme pode ser observado na Figura 06, o que evidencia menos área foliar para o biotipo $\mathrm{R}$ à partir dos 21 dias após o plantio.

A hipótese de que plantas resistentes sejam menos adaptadas do que plantas suscetíveis na ausência de pressão de seleção é baseada na possibilidade de que mutações em organismos biológicos podem ter efeitos deletérios ou pleitrópicos (gene que confere resistência pode interferir em características adaptativas) afetando a sobrevivência e/ou reprodução, fazendo com que plantas resistentes, possuam um custo adaptativo. No entanto, os resultados desta pesquisa não mostram evidências deste fenômeno para os biotipos $\mathrm{R}$ de Bidens pilosa/Bidens subalternans e Amaranthus quitensis.

Vários estudos indicam que os biotipos resistentes aos herbicidas inibidores da enzima ALS, não são necessariamente menos produtivos que os biotipos suscetíveis da mesma espécie. Christoffoleti (1993) desenvolveu pesquisa em campo e casa-de-vegetação, e não foi observado diferenças na adaptabilidade ecológica de biotipos resistentes e suscetíveis de Kochia scoparia. 


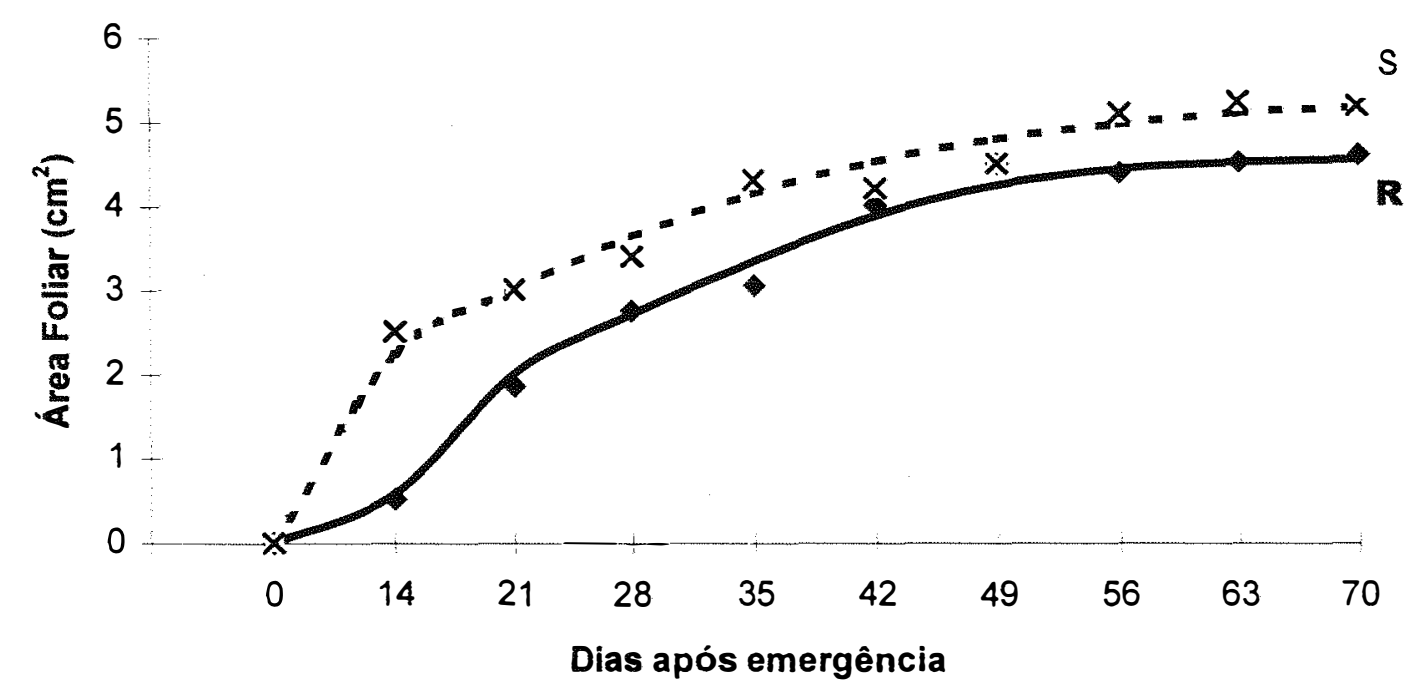

Figura 03- Área foliar dos biotipos resistentes e suscetíveis de B. pilosa/ B. subalternans.

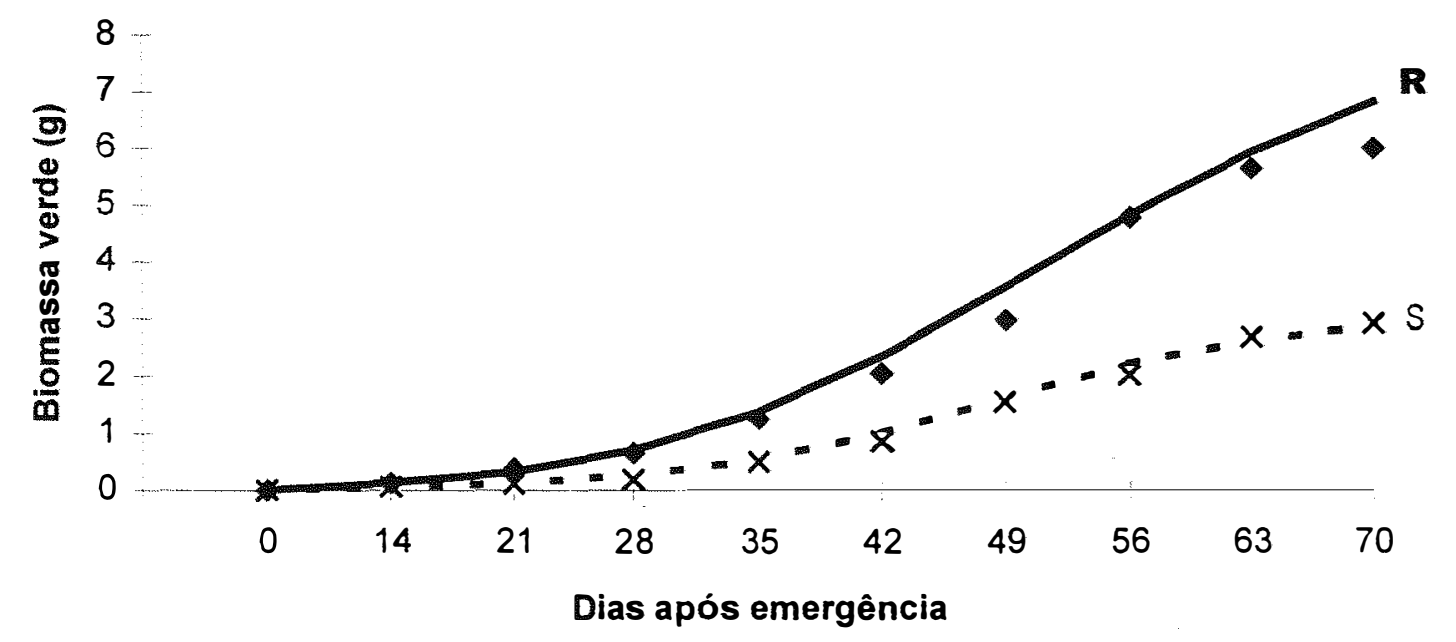

Figura 04- Curvas de produção de biomassa verde pelos biotipos resistentes e suscetíveis de $A$. quitensis . 
Tabela 13 - Parâmetros estimados para equação de Richards Function, na análise de crescimento dos biotipos resistentes e suscetíveis de Bidens pilosa/Bidens subalternans.

\begin{tabular}{ccccccc}
\hline Parâmetros & \multicolumn{3}{c}{ Biotipo Resistente } & \multicolumn{3}{c}{ Biotipo Suscetível } \\
\cline { 2 - 7 } & $\begin{array}{c}\text { Biomassa } \\
\text { verde }\end{array}$ & $\begin{array}{c}\text { Biomassa } \\
\text { seca }\end{array}$ & Area Foliar & $\begin{array}{c}\text { Biomassa } \\
\text { verde }\end{array}$ & $\begin{array}{c}\text { Biomassa } \\
\text { seca }\end{array}$ & Area Foliar \\
\hline A & 12,71 & 1,80 & 95,95 & 11,85 & 1,98 & 201,42 \\
$\mathbf{N}$ & 0,15 & 0,6 & 1,46 & 0,33 & 0,8 & 0,46 \\
K & 0,08 & 0,10 & 0,15 & 0,09 & 0,16 & 0,07 \\
To & 16,89 & 26,89 & 38,67 & 29,6 & 36,18 & 30,13 \\
\hline
\end{tabular}

Tabela 14 - Parâmetros estimados para equação de Richards Function, na análise de crescimento dos biotipos resistentes e suscetíveis de Amaranthus quitensis.

\begin{tabular}{ccccccc}
\hline Parâmetros & \multicolumn{3}{c}{ Biotipos Resistentes } & \multicolumn{2}{c}{ Biotipo Suscetível } \\
\cline { 2 - 7 } & $\begin{array}{c}\text { Biomassa } \\
\text { verde }\end{array}$ & $\begin{array}{c}\text { Biomassa } \\
\text { seca }\end{array}$ & Area Foliar & $\begin{array}{c}\text { Biomassa } \\
\text { verde }\end{array}$ & $\begin{array}{c}\text { Biomassa } \\
\text { seca }\end{array}$ & Area Foliar \\
\hline A & 8,67 & 2,32 & 175,22 & 3,03 & 3,02 & 201 \\
$\mathbf{N}$ & 0,47 & 0,82 & 1,09 & 1,18 & 1,26 & 0,46 \\
K & 0,07 & 0,08 & 0,13 & 0,13 & 0,15 & 0,07 \\
To & 39,3 & 51,5 & 40 & 49 & 47,12 & 30,13 \\
\hline
\end{tabular}




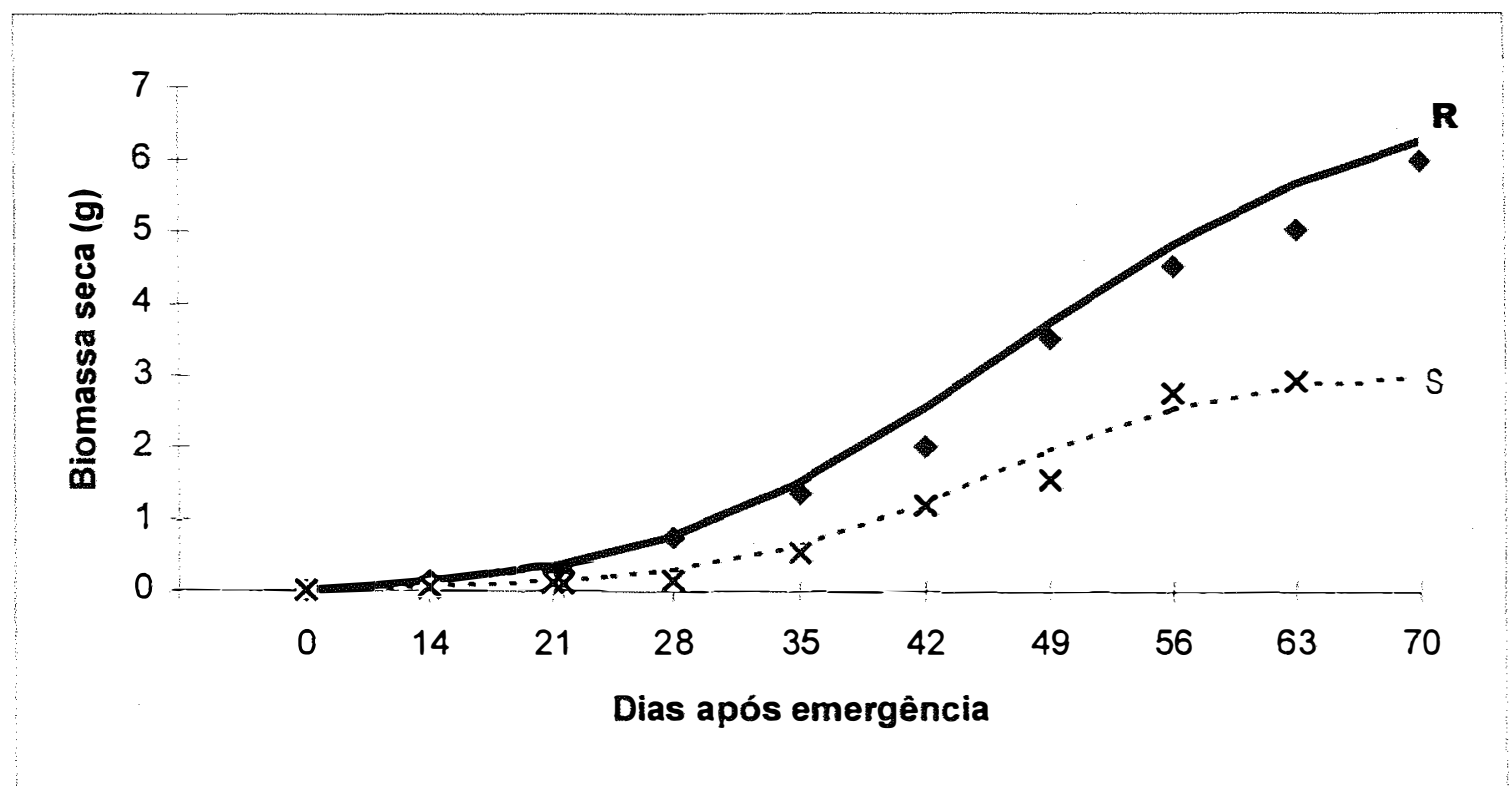

Figura 05- Curvas de produção de biomassa seca pelos biotipos resistentes e suscetíveis de $A$. quitensis .

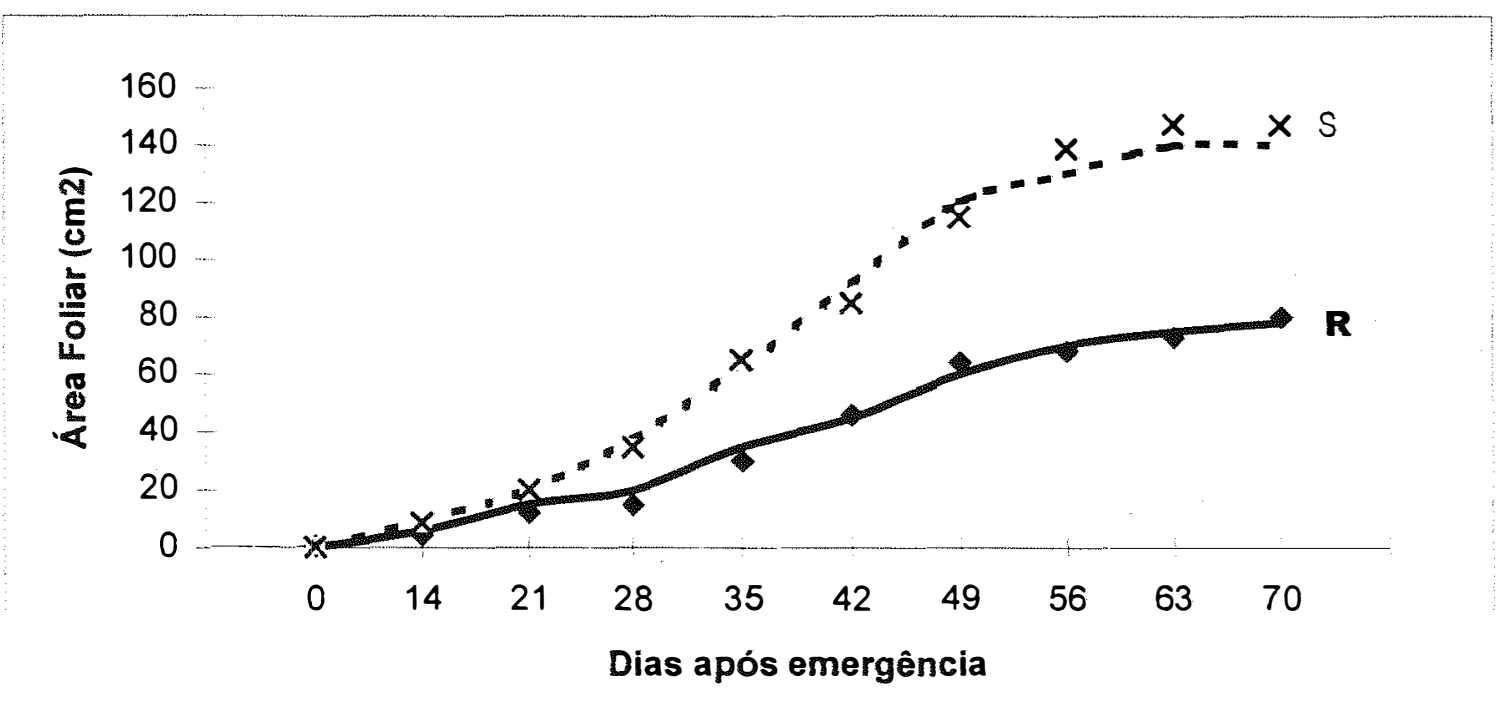

Figura 06- Área foliar dos biotipos resistentes e suscetíveis de A. quitensis . 
Gurjeet et al. (1996), também pesquisaram a adptabilidade ecológica de plantas resistentes e suscetíveis e verificaram não haver diferenças entre a velocidade de germinação e o peso da biomassa seca entre os biotipos de Lolium rigidium. Dyer (1993), constatou que biotipos resistentes aos herbicidas inibidores da ALS de algumas espécies apresentam uma maior velocidade de germinação que os biotipos suscetíveis, fato associado a um maior nível de aminoácidos leucina e valina nas sementes dos biotipos resistentes.

Uma estimativa exata da adaptabilidade dos biotipos resistentes e suscetíveis na ausência de herbicidas é bastante difícil de obter, porém é bastante útil nos modelos de predição se um biotipo resistente pode ser substituído pelo suscetível na ausência de pressão de seleção, pois, se um indivíduo é mais adaptado, normalmente mais competitivo, terá a capacidade de aumentar sua proporção ao longo do tempo e eliminar os indivíduos menos adaptados ou competitivos. Os três maiores problemas para se determinar a adaptabilidade ecológica são: (1) escolha do material suscetível para comparação; (2) condições experimentais onde as adaptabilidades de resistentes e suscetíveis serão comparadas; (3) e as características que serão usadas para medir a adaptabilidade, como biomassa seca, área foliar, vigor de plantas, viabilidade de sementes, etc.

\subsection{Teste rápido da sensibilidade da ALS dos biotipos $\mathrm{R}$ e $\mathrm{S}$ de Bidens pilosa/Bidens subalternans e Amaranthus quitensis através de bioensaio}

Os dados de acumulação de acetoína pelos biotipos resistentes e suscetíveis de Bidens pilosa/Bidens subalternans e Amaranthus quitensis, devido ao efeito do ácido ciclopropanodicarboxólico (CPCA), podem ser analisados nas Tabelas 15 e 16 respectivamente. Os dados referem-se às leituras de absorbância realizadas em espectrofotômetro à $530 \mathrm{~nm}$, subtraindo-se os valores obtidos do controle zero. 
Tabela 15 - Acumulação de acetolactato pelos biotipos resistentes e suscetíveis de Bidens pilosa/Bidens subalternans.

\begin{tabular}{|c|c|c|c|c|c|}
\hline \multirow[b]{2}{*}{ Tratamentos } & \multirow{2}{*}{$\begin{array}{c}\text { Dose } \\
(\mathrm{ml} \mathrm{ou} \\
\text { g/100ml Ho }\end{array}$} & \multicolumn{2}{|c|}{ Biotipo Resistente } & \multicolumn{2}{|c|}{ Biotipo Suscetível } \\
\hline & & $\begin{array}{l}\text { Reação } \\
\text { Colorida }\end{array}$ & Acetoína & $\begin{array}{l}\text { Reação } \\
\text { Colorida }\end{array}$ & Acetoína \\
\hline $1-\mathrm{CPCA}$ & 0,5 & Vermelha & 2,16 & Vermelha & 1,98 \\
\hline 2-CPCA + CHLORIMURON & $0,50+0,20$ & Vermelha & 1,81 & Marrom & 0,3 \\
\hline 3-CPCA + IMAZETHAPYR & $0,50+0,25$ & Rosa & 1,7 & Marrom & 0,1 \\
\hline 4- TESTEMUNHA & 0 & Marrom & 0 & Marrom & 0 \\
\hline
\end{tabular}

Tabela 16 - Acumulação de acetolactato pelos biotipos resistentes e suscetíveis de Amaranthus quitensis.

\begin{tabular}{lccccc}
\hline \multirow{2}{*}{ Tratamentos } & Dose & \multicolumn{2}{c}{ Biotipo Resistente } & \multicolumn{2}{c}{ Biotipo Suscetível } \\
\cline { 2 - 6 } & $\begin{array}{c}\mathbf{( m l ~ o u ~} \\
\text { g/100 ml H2 } \mathbf{~})\end{array}$ & $\begin{array}{c}\text { Reação } \\
\text { Colorida }\end{array}$ & Acetoína & $\begin{array}{c}\text { Reação } \\
\text { Colorida }\end{array}$ & Acetoína \\
\hline 1 - CPCA & 0,5 & Rosa & 1,57 & Rosa & 0,78 \\
2 - CPCA + CHLORIMURON & $0,50+0,20$ & Rosa & 1,53 & Marrom & 0,31 \\
3 - CPCA + IMAZETHAPYR & $0,50+0,25$ & Rosa & 1,7 & Marrom & 0,38 \\
4- TESTEMUNHA & 0 & Marrom & 0 & Marrom & 0 \\
\hline
\end{tabular}


Os resultados das Tabelas 15 e 16 indicam que os herbicidas inibidores da ALS chlorimuron-ethyl e imazethapyr não inibem a enzima ALS nos biotipos resistentes de ambas as espécies, pois o desenvolvimento da coloração rosa ou vermelha mostra a formação de acetoína, que é a indicação de que houve acumulo de acetolactato que reagiu com creatina e naphtol. Em biotipos S, como a ALS foi inibida pelos herbicidas, não houve acúmulo de acetolactato, portanto, não houve a formação do complexo colorido. Estes resultados são comprovados pelas leituras de absorbância comparativas com a testemunha no espectofotômetro.

Gerwick et al. (1993), utilizando CPCA, para a inibição da enzima KARI, distinguiu claramente os biotipos resistentes e suscetíveis de Xanthium strumarium ao herbicida imazaquim. Do mesmo modo, Simpson et al. (1995), constataram a acumulação de acetolactato em folhas de Clycine $\max$ (L) Merrill, Zea mays L., Amaranthus hybridus L., Xanthium strumarium L. e Sorghum bicolor(L) Moench, após a aplicação foliar de $766 \mathrm{~g} /$ ha de CPCA, verificando também, que houve maior acumulo de acetolactato em folhas jovens de soja.

O bioensaio in vitro com a enzima ALS, através da acumulação diferencial de acetoína, é um método bastante prático e eficiente no diagnóstico de resistência de plantas daninhas aos herbicidas, inibidores da ALS.

4.5. Determinação da resistência cruzada e curvas de dose-resposta de populações resistentes (R) e suscetíveis (S) de Bidens pilosa/Bidens subaternans e Amaranhtus quitensis aos herbicidas inibidores da ALS

Os resultados de produção de biomassa verde, biomassa seca e a porcentagem de controle visual dos biotipos resistentes e suscetíveis de Bidens pilosa/Bidens subalternans, foram submetidos à análise de regressão não linear, modelo proposto por Seefeldt (1995), sendo que as curvas de dose-resposta da porcentagem de controle aos 7 e 14 DAT estão representados nas Figuras 07 a 12. 


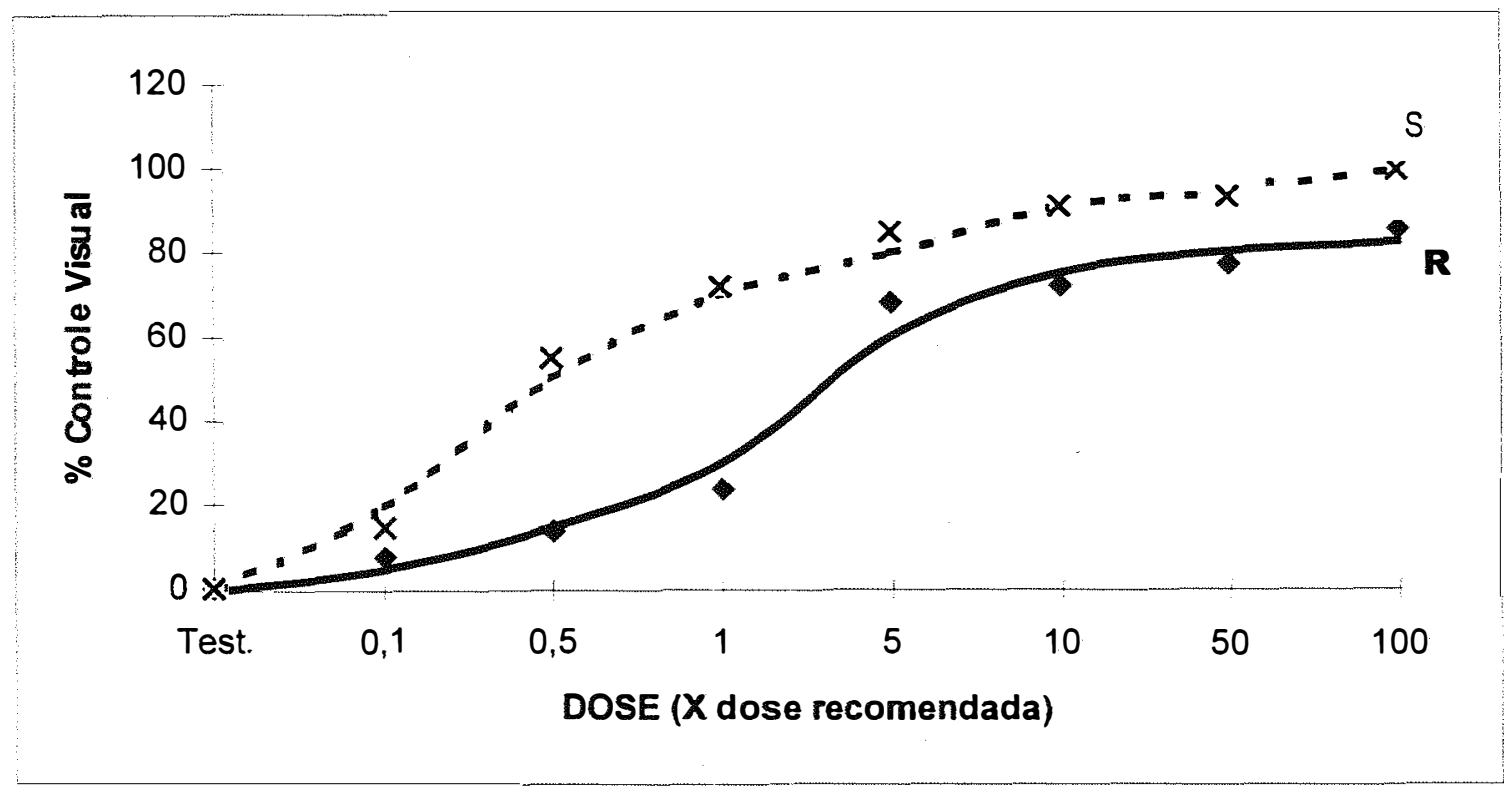

Figura 07- Curvas de dose-resposta da porcentagem de controle dos biotipos resistentes e suscetíveis de B. pilosa/B. subalternans aos 7 DAT com chlorimuron-ethyl, segundo o modelo log-logístico.

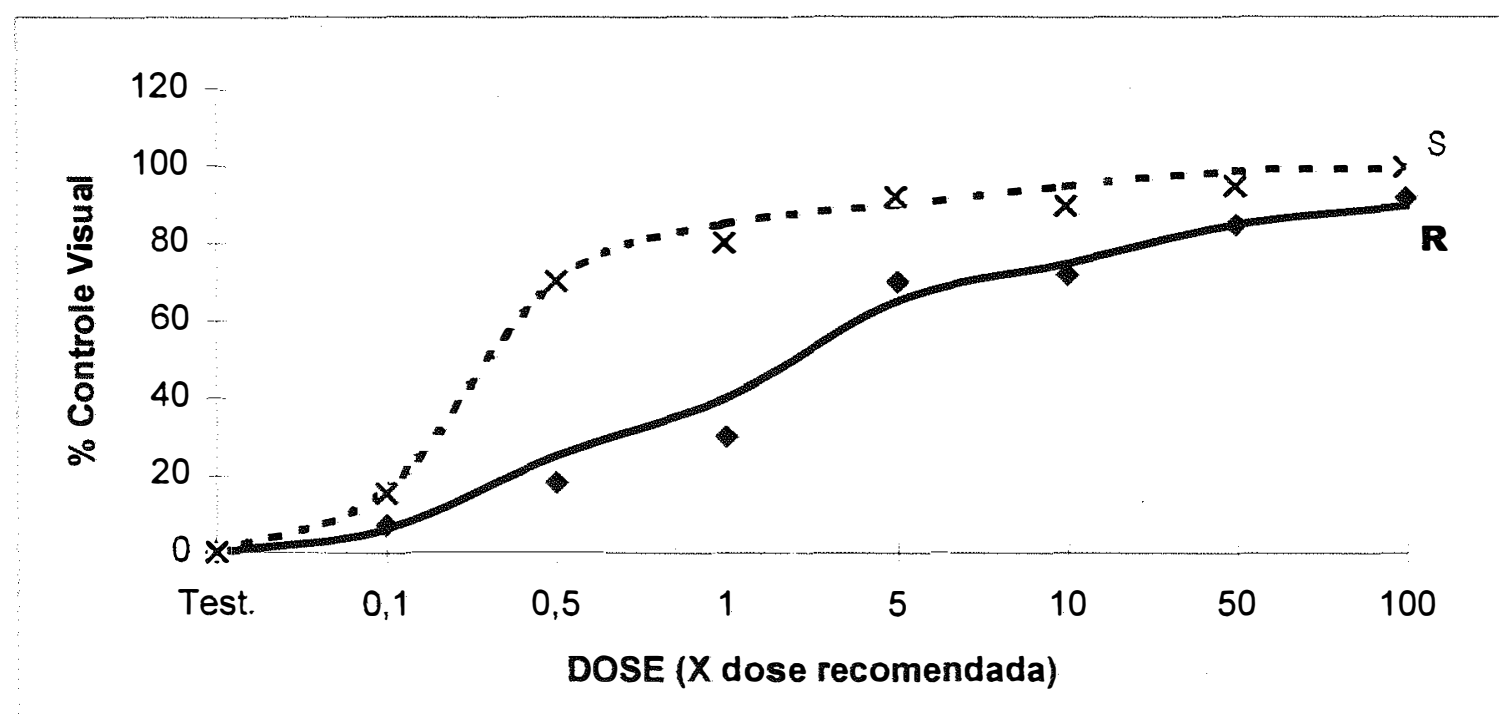

Figura 08- Curvas de dose- resposta da porcentagem de controle dos biotipos resistentes e suscetíveis de $B$. pilosa/B. subalternans aos 14 DAT com chlorimuron-ethyl, segundo o modelo log-logístico. 


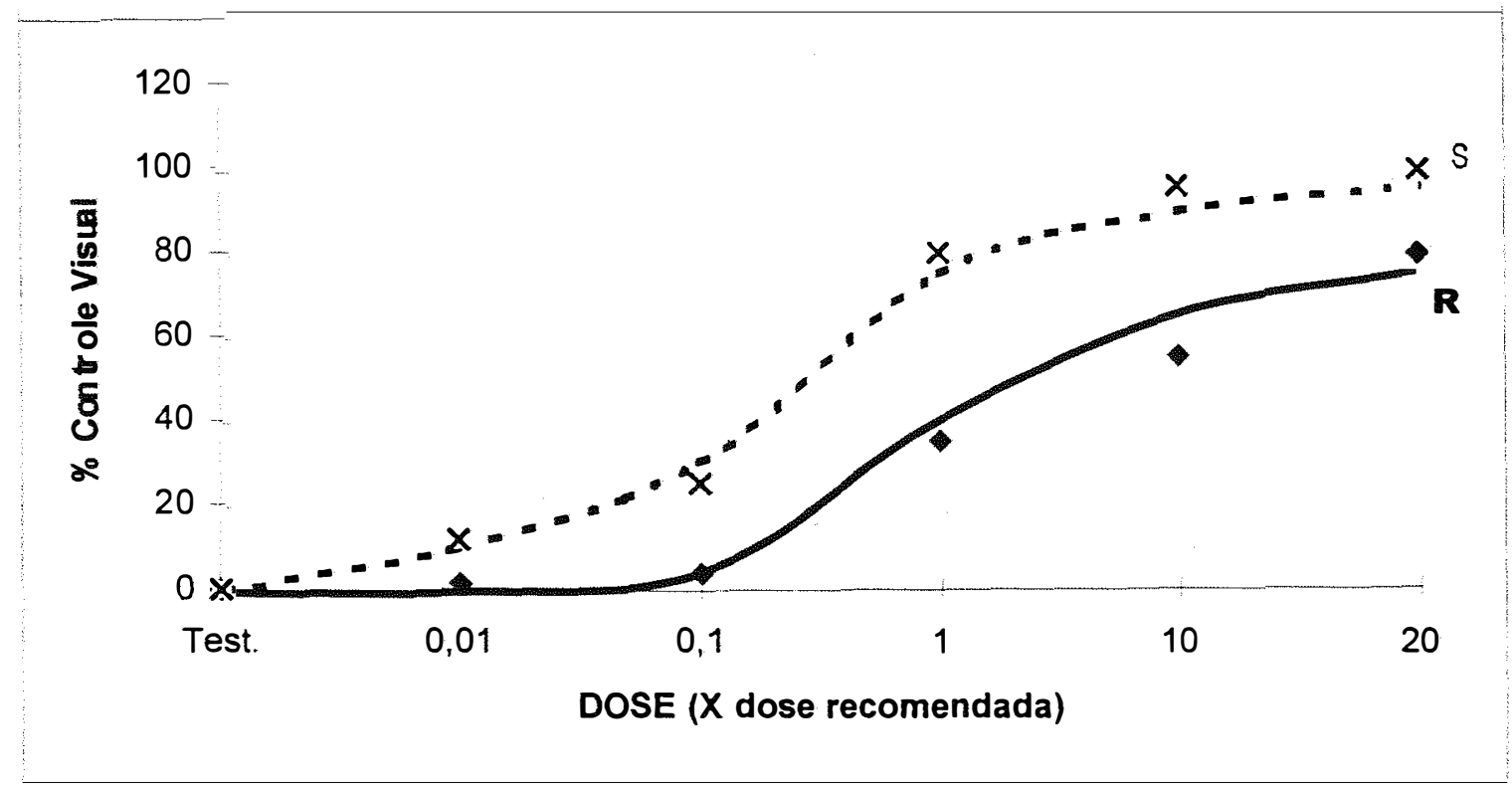

Figura 09 - Curvas de dose-resposta da porcentagem de controle dos biotipos resistentes e suscetíveis de $B$. pilosa/B. subalternans aos 7 DAT com nicosulfuron, segundo o modelo log-logístico.

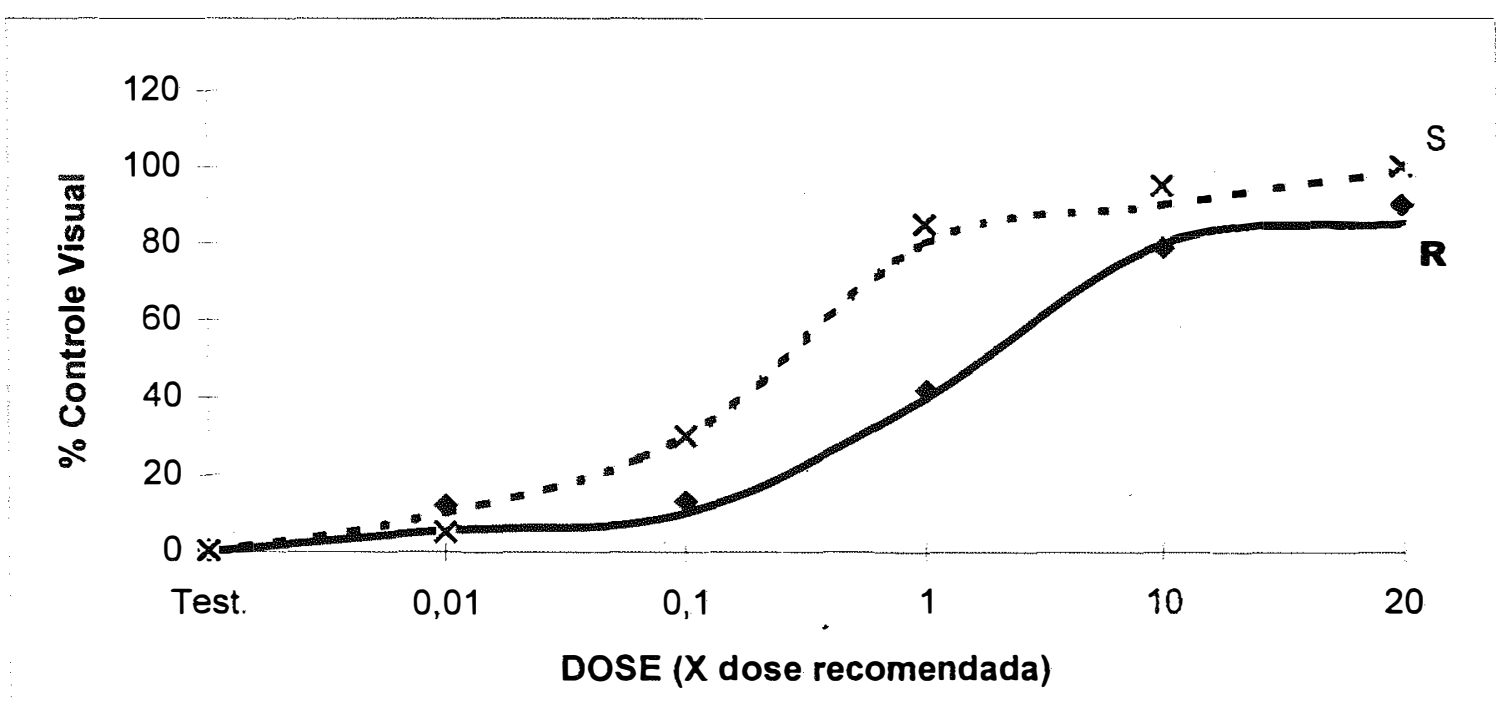

Figura 10 - Curvas de dose-resposta da porcentagem de controle dos biotipos resistentes e suscetíveis de $B$. pilosa/B. subalternans aos 14 DAT com nicosulfuron, segundo o modelo log-logístico. 


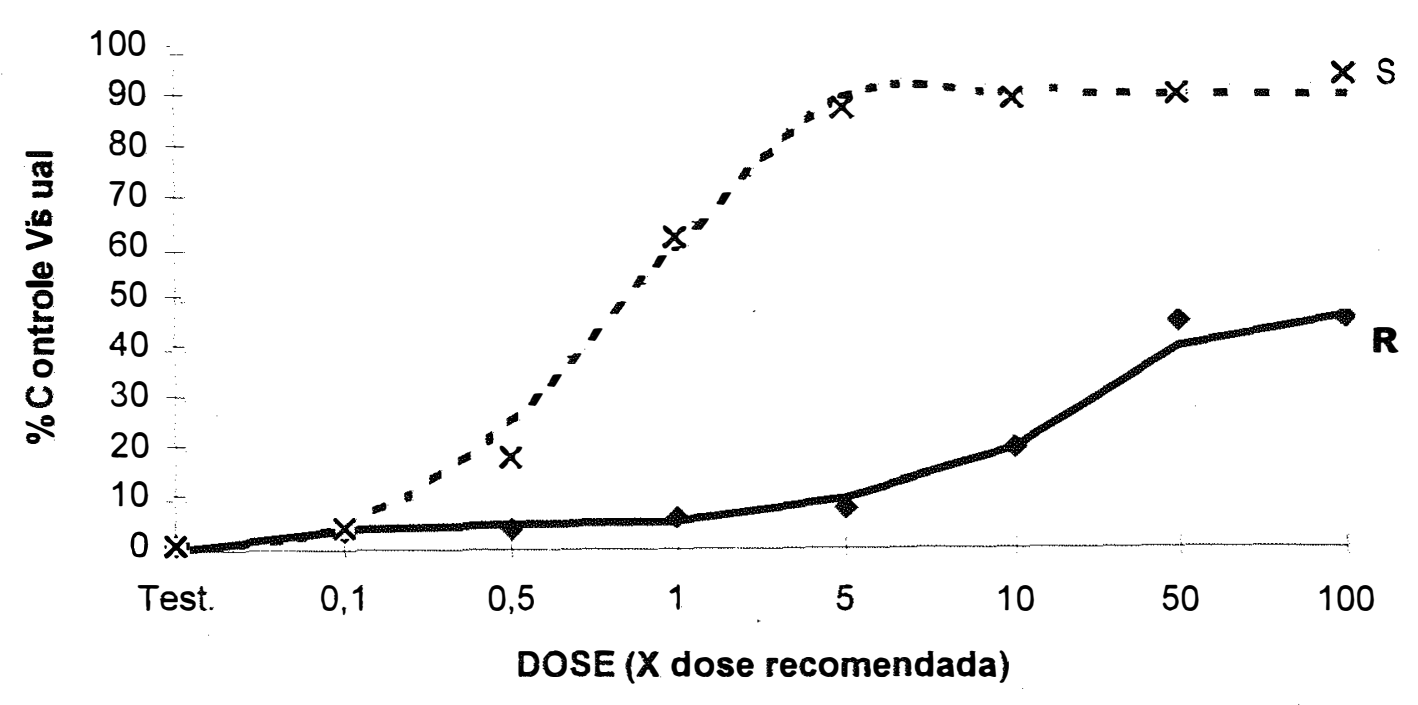

Figura 11 - Curvas de dose-resposta da porcentagem de controle dos biotipos resistentes e suscetíveis de $B$. pilosa/B. subalternans aos 7 DAT com imazethapyr, segundo o modelo log-logístico.

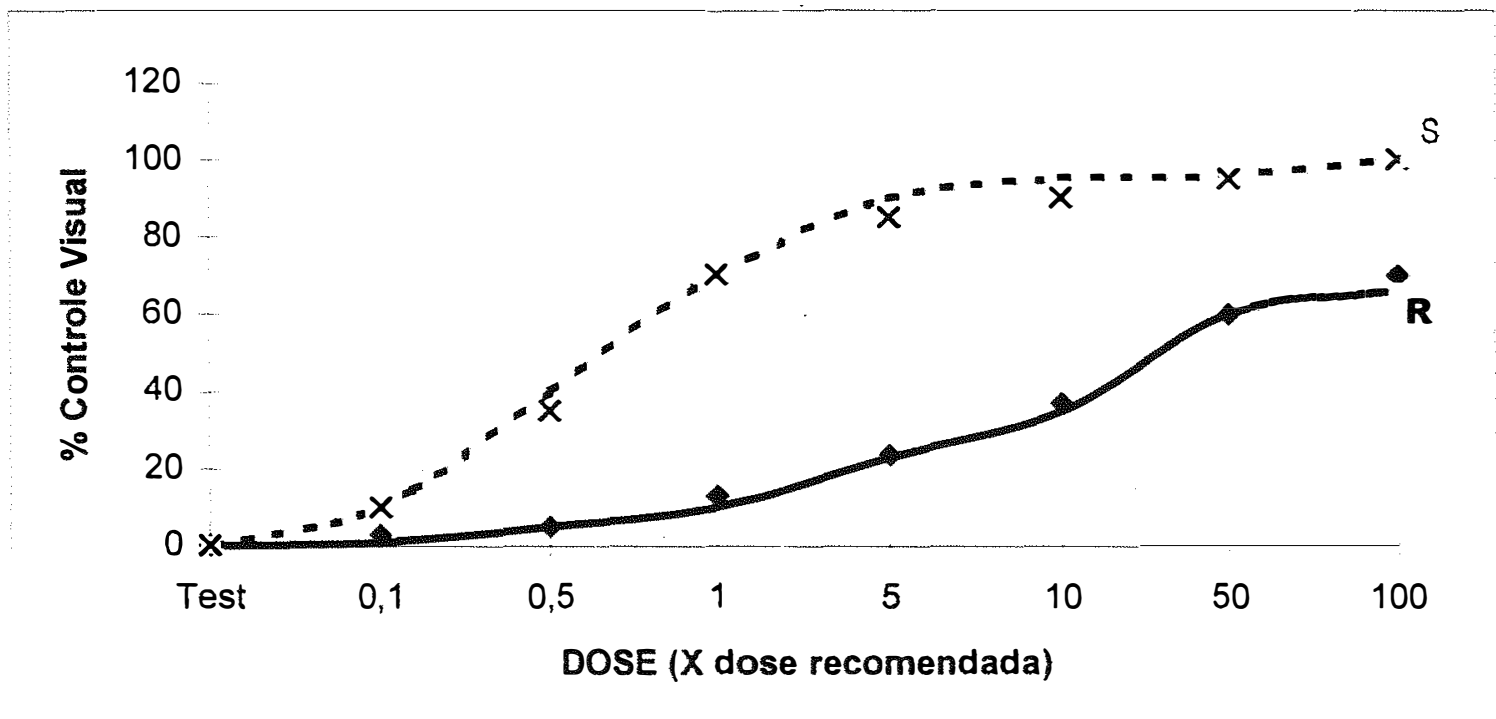

Figura 12 - Curvas de dose-resposta da porcentagem de controle dos biotipos resistentes e suscetíveis de $B$. pilosa/B. subalternans aos 14 DAT com imazethapyr, segundo o modelo log-logístico. 
Em todos os casos, o segmento da curva referente ao biotipo suscetível se encontra na posição superior do gráfico, enquanto que o segmento da curva referente ao biotipo resistente está abaixo, indicando uma menor porcentagem de controle dos biotipos resistentes pelos herbicidas inibidores da ALS, mesmo nas doses acima das recomendadas.

As Figuras 13 a 18 correspondem a produção de biomassa verde e seca pelos biotipos resistentes e suscetíveis de Bidens pilosalBidens subalternans, quando tratados com chlorimuron-ethyl, nicosulfuron e imazethapyr. O biotipo suscetível, apresenta uma queda acentuada na produção de biomassa, mesmo nas doses menores do que a recomendada, enquanto que, as curvas correspondentes a resposta do biotipo resistente, posicionam-se sempre acima, no gráfico, indicando um menor efeito dos herbicidas na produção de biomassa.

O GR 50 , visto na Tabela 17, comprova a diferença de sensibilidade entre os biotipos. O biotipo resistente necessitou de doses maiores do que a comerciais, dos três herbicidas, para ter sua biomassa vegetal reduzida em $50 \%$, já o biotipo suscetível teve sua biomassa reduzida em $50 \%$, até mesmo em doses menores do que as comerciais. A Tabela 19, indica que a taxa de resistência dos biotipos de Bidens pilosa/Bidens subalternans ao chlorimuron é de 9,90; ao nicosulfuron é de 9,07 e ao imazethapyr de 27,03. Estes resultados evidenciam a resistência cruzada destes biotipos aos herbicidas inibidores da ALS, dos grupos químicos das sulfoniluréias e imidazolinonas.

As mesmas considerações podem ser feitas utilizando-se os dados de produção de biomassa verde, biomassa seca e porcentagem de controle visual de biotipos resistentes e suscetíveis de Amaranthus quitensis, aos herbicidas inibidores da ALS. Para este conjunto de dados, foram utilizados dois modelos de regressão; um que representa uma hipérbole retangular, para as respostas de controle visual aos 7 e 14 DAT; e um exponencial para as respostas de produção de biomassa verde e seca (Tabela 18). 


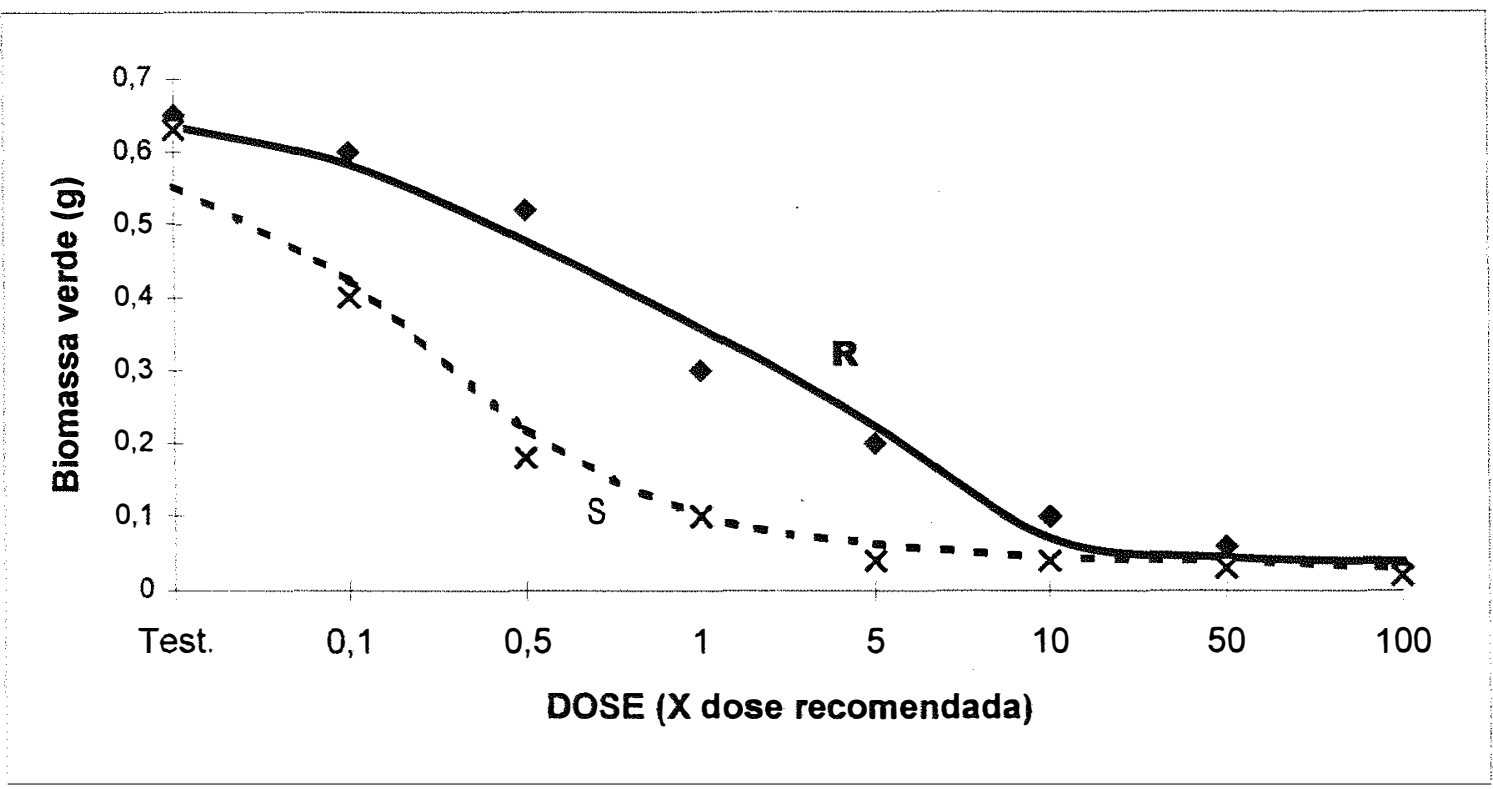

Figura 13- Curvas de dose-resposta da produção de biomassa verde pelos biotipos resistentes e suscetíveis de Bidens pilosa/B. subalternans, após tratamento com chlorimuron-ethyl, segundo o modelo log-logístico.

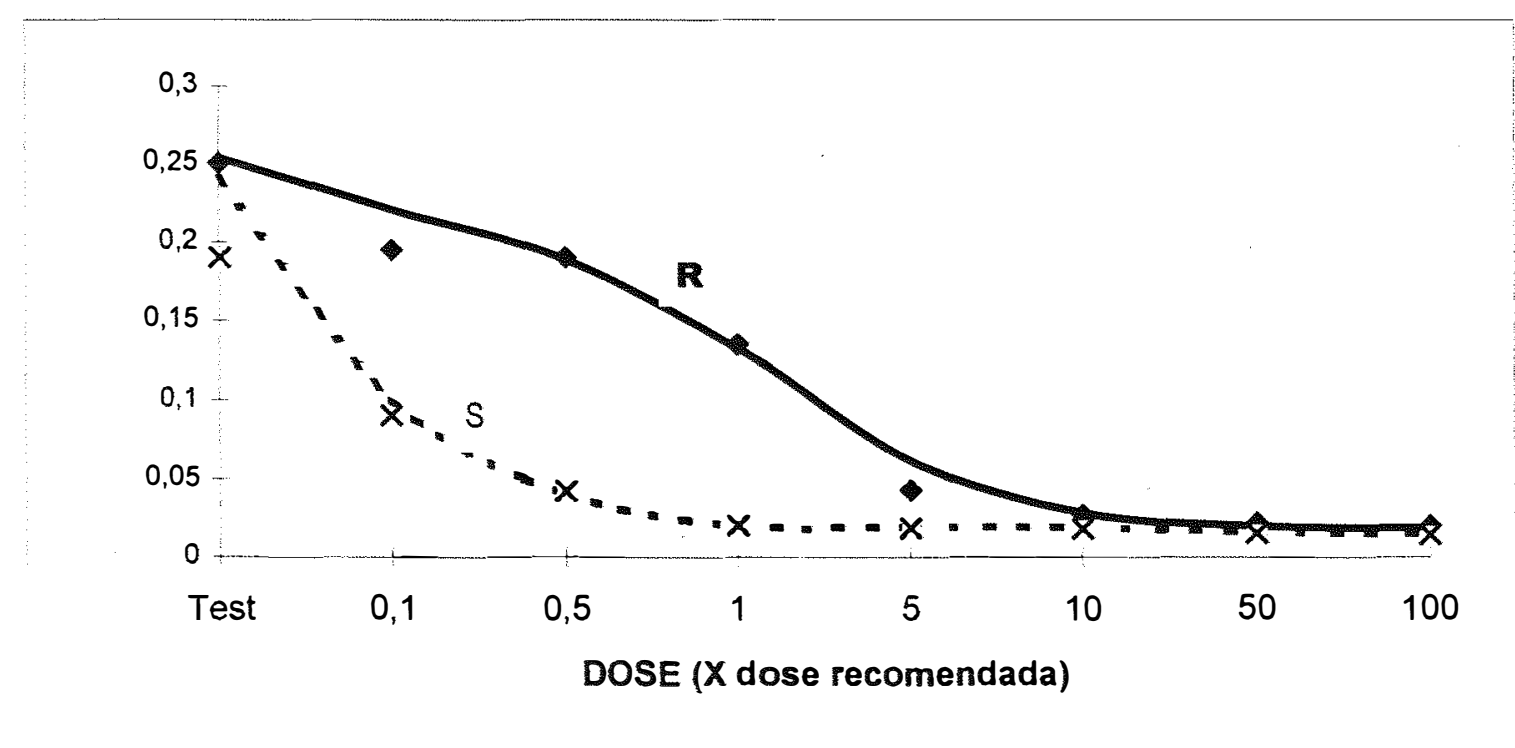

Figura 14- Curvas de dose-resposta da produção de biomassa seca pelos biotipos resistentes e suscetíveis de Bidens pilosa/B. subalternans, após tratamento com chlorimuron-ethyl, segundo o modelo log-logistico. 


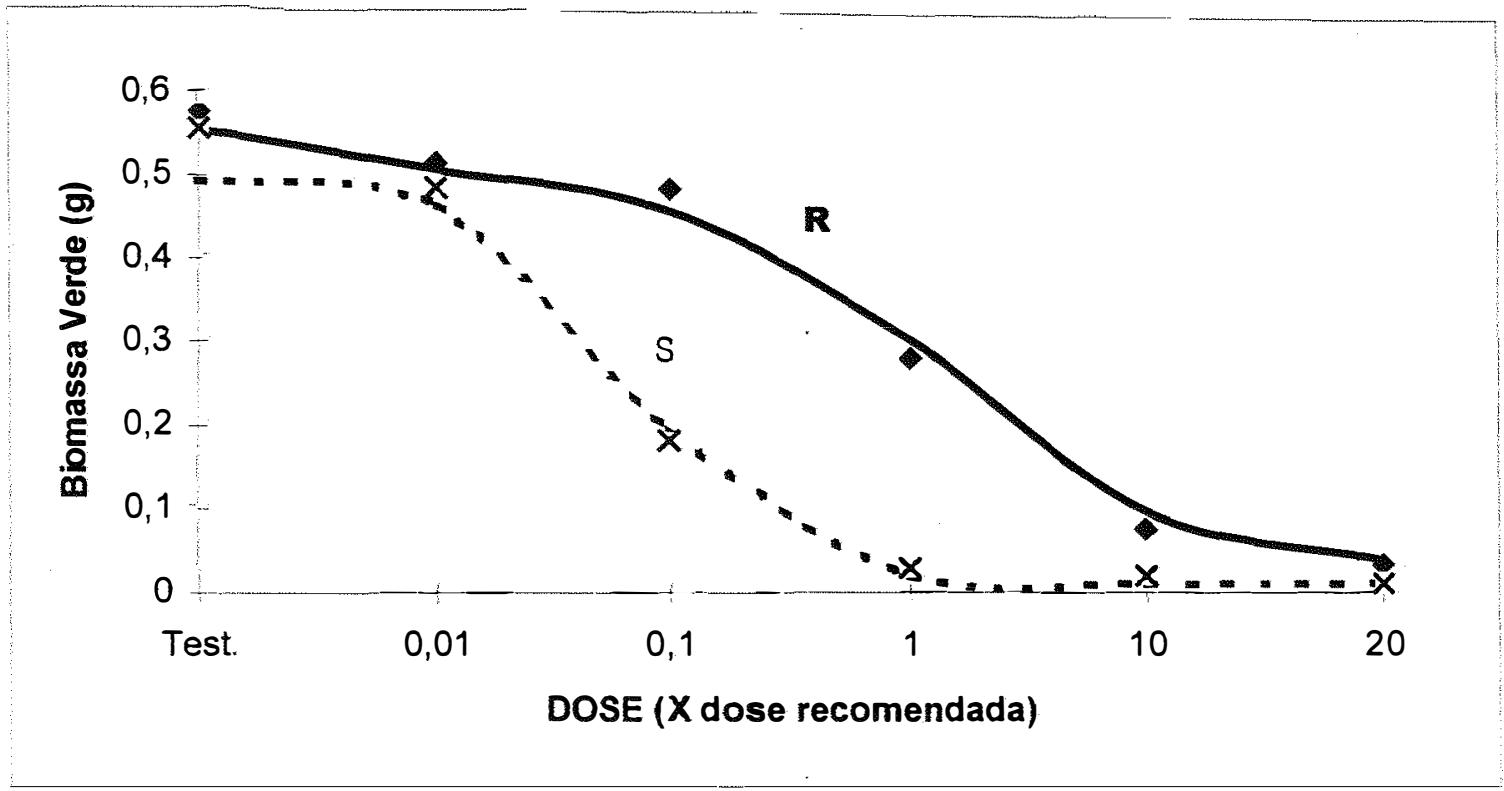

Figura 15 - Curvas de dose-resposta da produção de biomassa verde pelos biotipos resistentes e suscetíveis de B. pilosa/B. subalternans, após tratamento com nicosulfuron, segundo o modelo log-logístico.

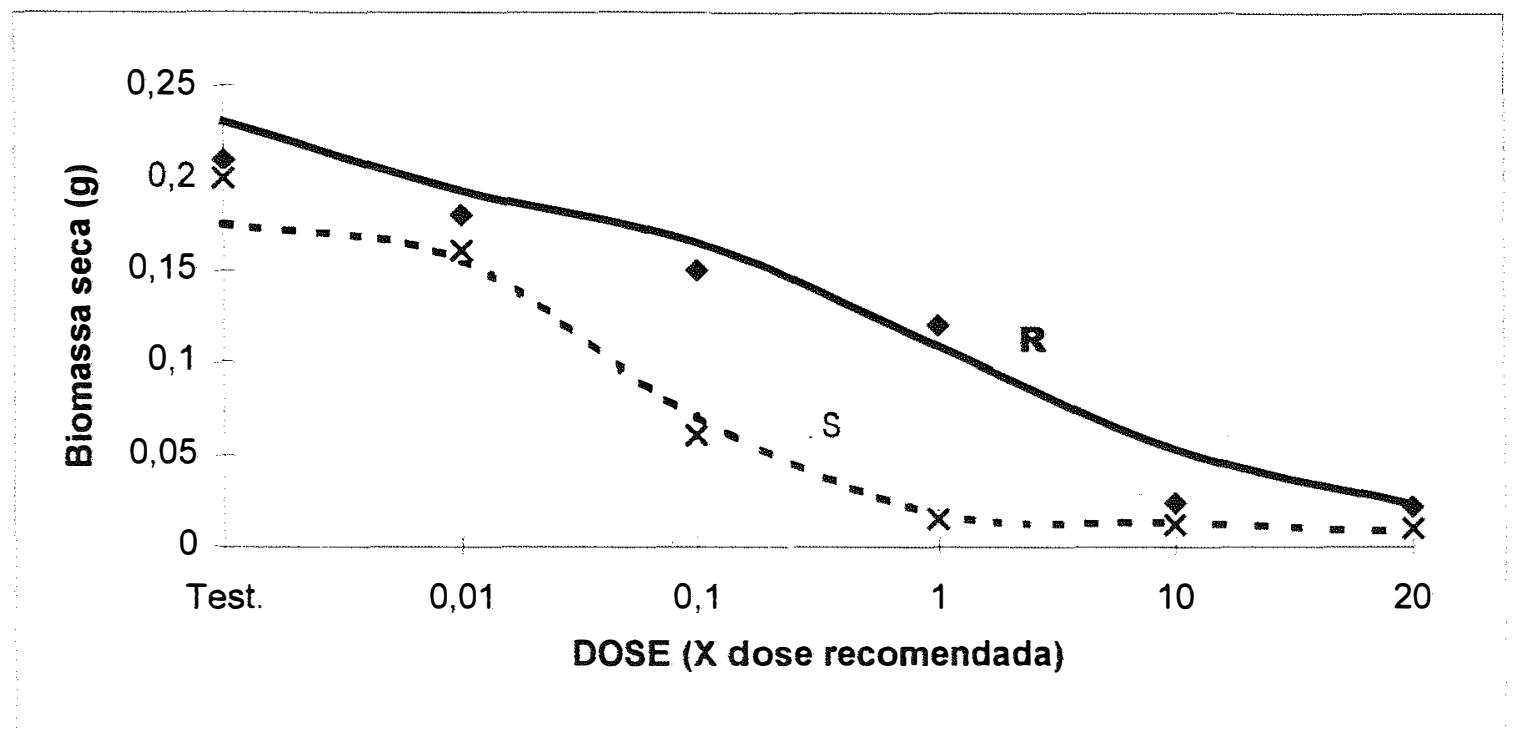

Figura 16 - Curvas de dose-resposta da produção de biomassa seca pelos biotipos resistentes e suscetíveis de $B$. pilosa/B. subalternans, após tratamento com nicosulfuron, segundo o modelo log-logístico. 


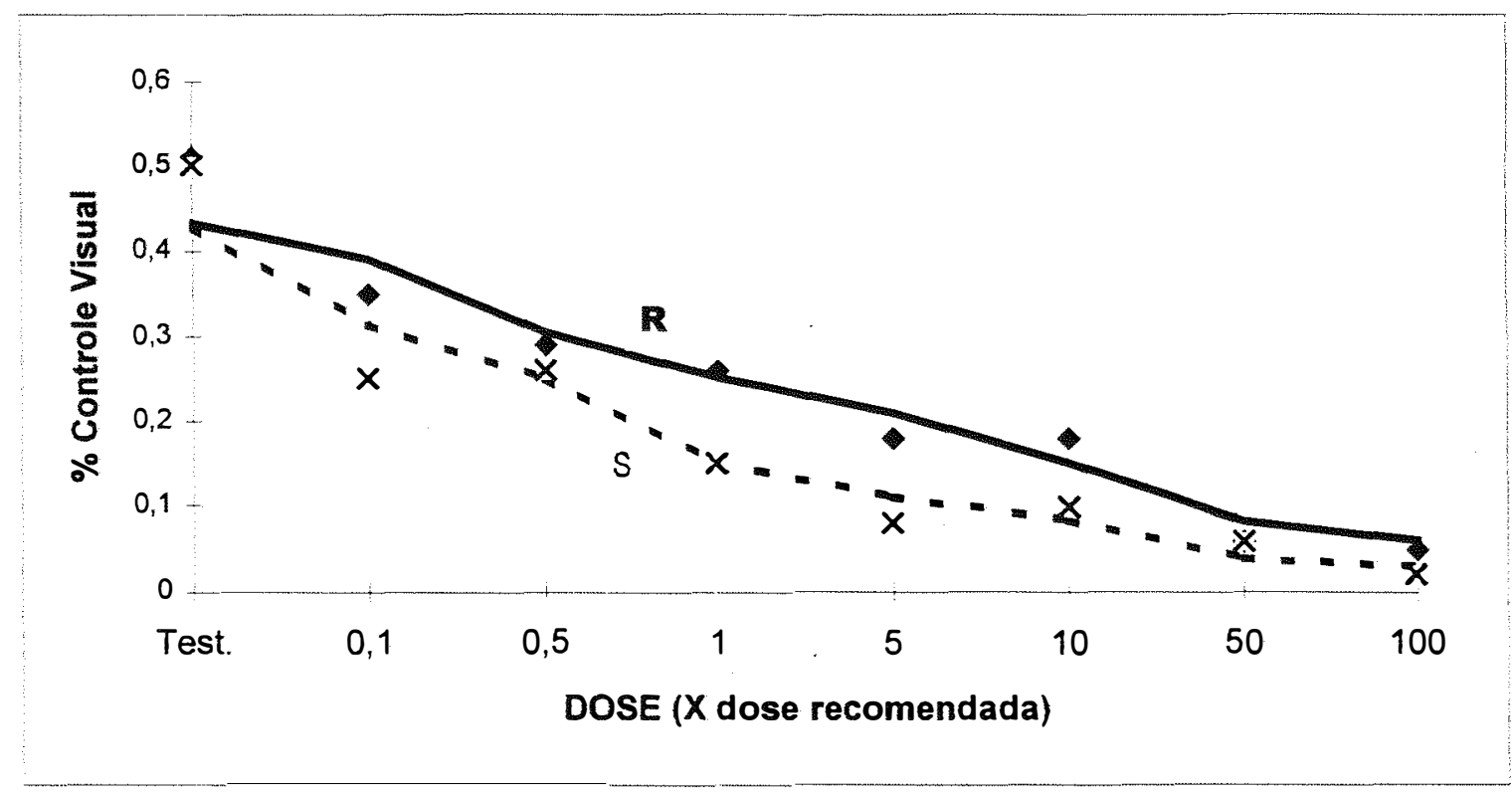

Figura 17 - Curvas de dose-resposta da produção de biomassa verde pelos biotipos resistentes e suscetíveis de B. pilosa/B. subalternans, após tratamento com imazethapyr, segundo o modelo log-logístico.

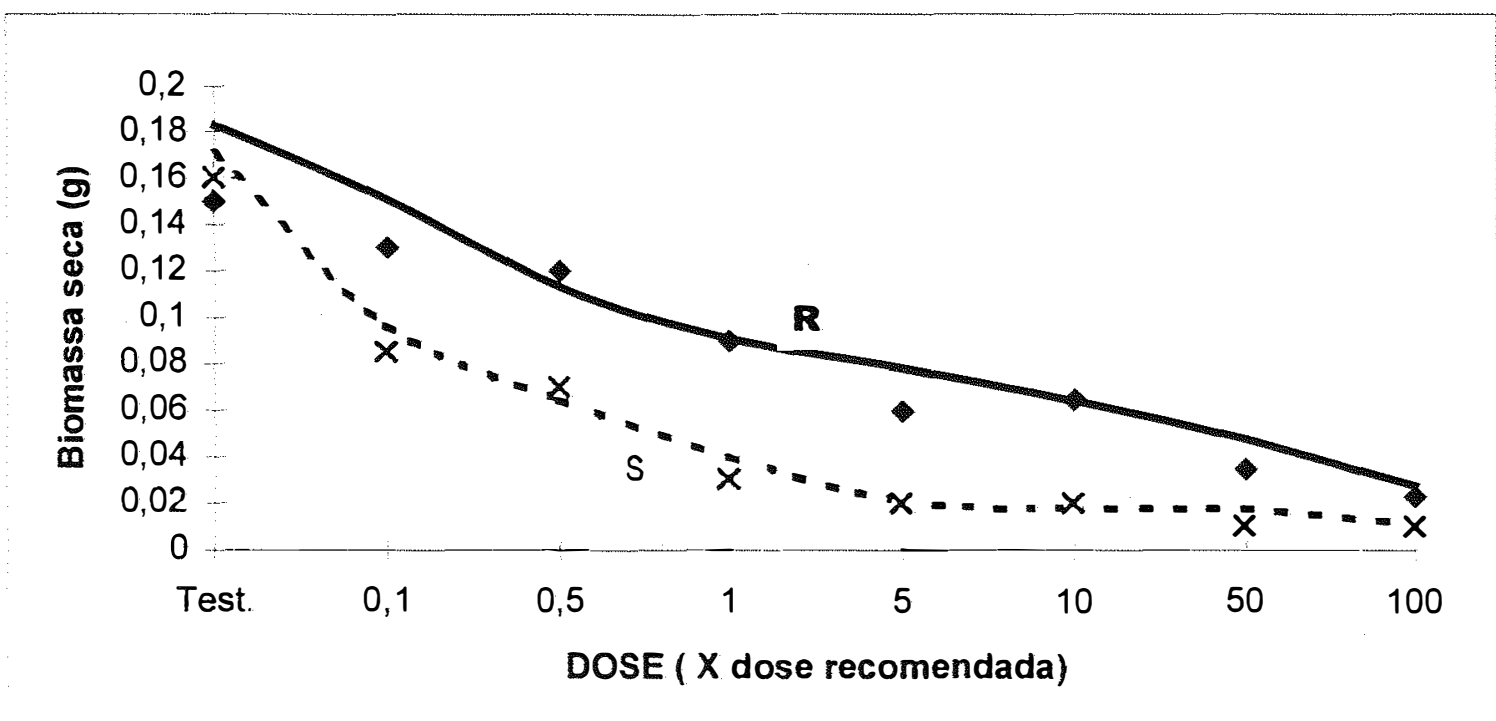

Figura 18 - Curvas de dose-resposta da produção de biomassa seca pelos biotipos resistentes e suscetíveis de B. pilosa/B. subalternans, após tratamento com imazethapyr, segundo modelo log-logístico. 

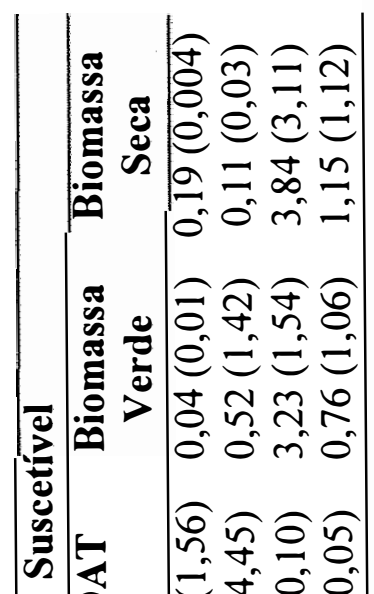

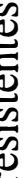

0
0
0
0
0
0
0
0

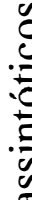

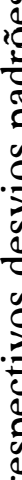

范

ปับ

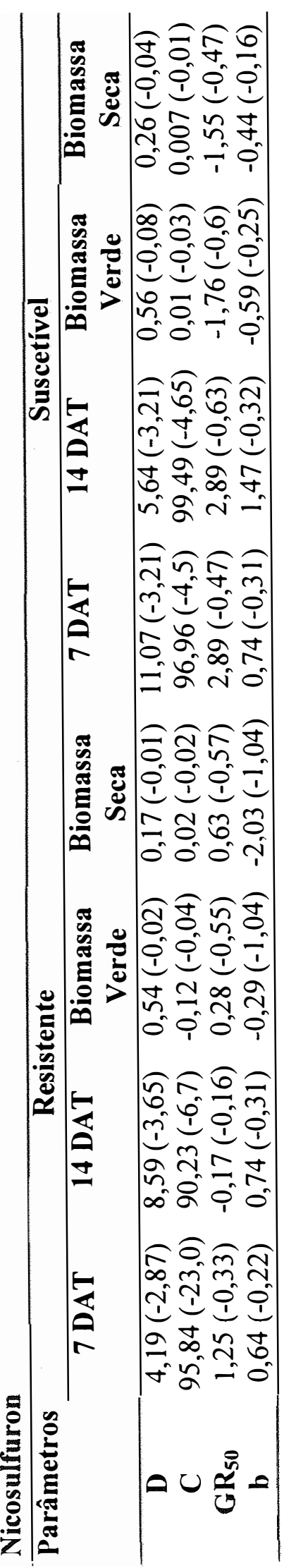

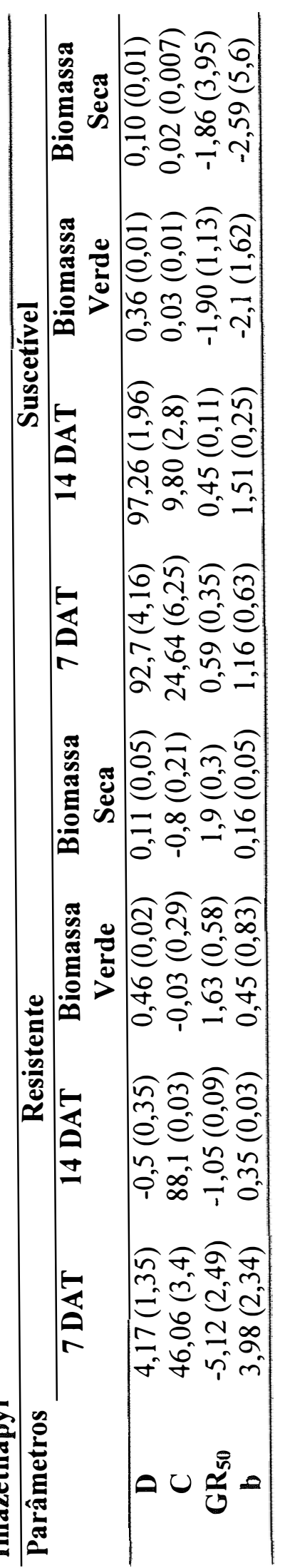




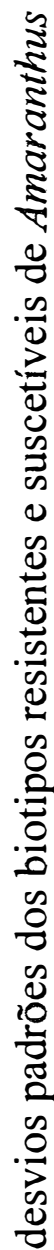

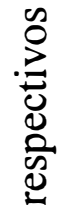

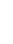

泀 :

ह

กี

$\overline{0}$
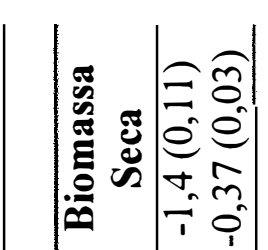

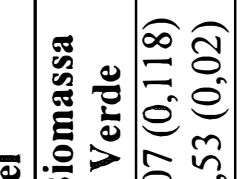

: in

กิ

(

I

츠

ấ

$\approx \infty$

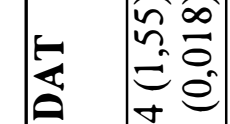

a

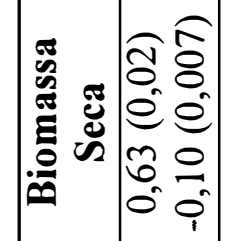

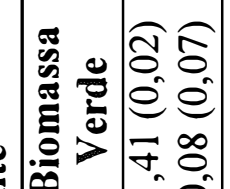

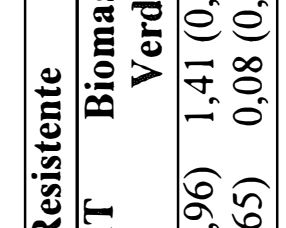

$\mathscr{2}$

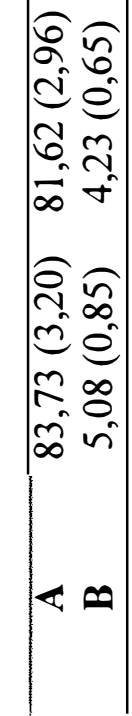

$\mid$

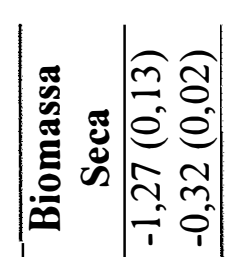

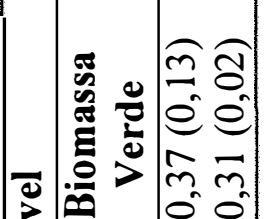

는

造

के

ন্ิ

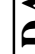

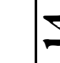
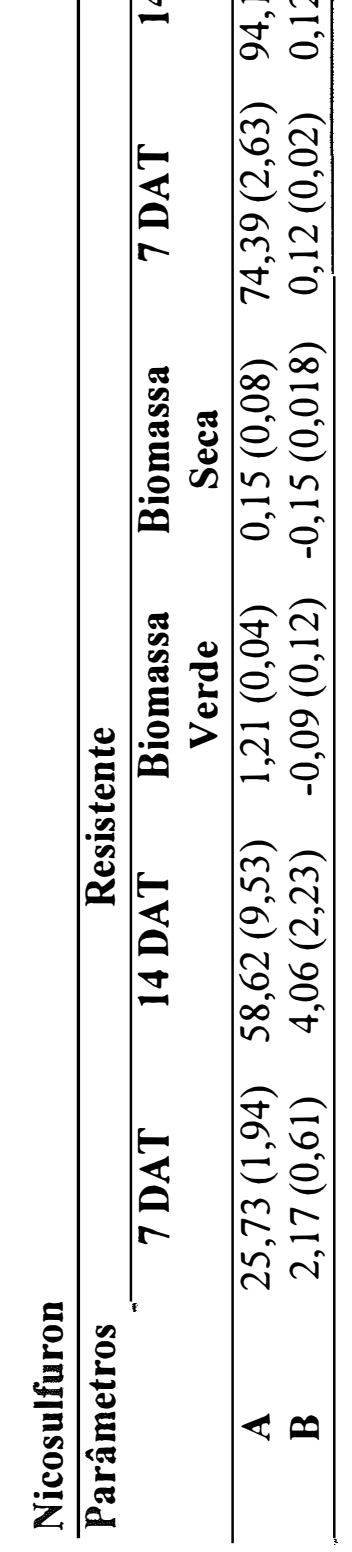

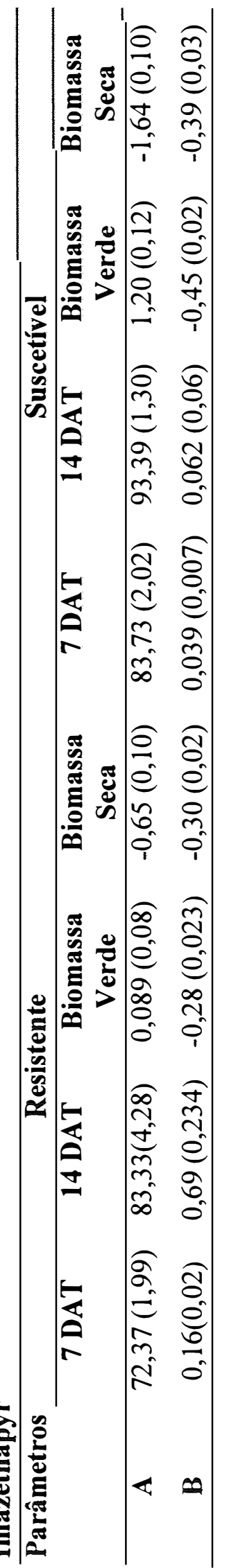


As Figuras 19 a 24 representam as curvas de dose-resposta dos biotipos estudados, com relação a porcentagem de controle visual aos 7 e 14 DAT e as Figuras 25 a 30, representam as curvas de produção de biomassa verde e seca, após tratamento com chlorimuron-etil, nicosulfuron e imazethapyr. As curvas possuem o mesmo padrão encontrados nos biotipos de Bidens pilosa/Bidens subalternans, ou seja o biotipo resistente não foi controlado satisfatoriamente pelos herbicidas inibidores da ALS, independente do grupo químico utilizado.

Do mesmo modo, a dose necessária para reduzir em $50 \%$ da biomassa vegetal $\left(\mathrm{GR}_{50}\right.$ ) dos biotipos resistentes foi de 2,45 para o herbicida imazethapyr de 6,8 para o herbicida chlorimuron, 23,54 para o herbicida nicosulfuron (Tabela 20). A taxa de resistência vista na Tabela 20 evidencia o alto grau de resistência dos biotipos de Amaranthus quitensis provenientes da Argentina, aos herbicidas inibidores da ALS, podendo chegar ao nível de 181,08.

Os resultados encontrados, evidenciam a existência do fenômeno de resistência cruzada dos biotipos de ambas as espécies aos herbicidas pertencentes aos grupos químicos das imidazolinonas e sulfoniluréias. Powles \& Howat (1990) descreveram a resistência cruzada de plantas daninhas quando biotipos que desenvolveram a resistência após uma pressão de seleção por um herbicida, exibem resistência a outro herbicida, geralmente apresentanto o mesmo mecanismo de ação. 
Tabela 19 - Estimativa do $\mathrm{GR}_{50}$ e taxa de resistência (R/S) dos biotipos resistentes e suscetíveis de Bidens pilosa/Bidens subalternans.

\begin{tabular}{lccc}
\hline \multicolumn{1}{c}{ Herbicidas } & \multicolumn{2}{c}{ GR $_{\mathbf{5 0}}(\mathbf{1 4}$ DAT $)$} & R/S \\
\cline { 2 - 3 } & Resistente & Suscetível & \\
\hline Chlorimuron - ethyl & 1,49 & 0,15 & 9,90 \\
Nicosulfuron & 1,27 & 0,14 & 9,07 \\
Imazethapyr & 20,08 & 0,74 & 27,03 \\
\hline
\end{tabular}

Tabela 20 - Estimativa do $\mathrm{GR}_{50}$ e taxa de resistência (R/S) dos biotipos resistentes e suscetíveis de $A$. quitensis.

\begin{tabular}{lccc}
\hline \multirow{2}{*}{ Herbicidas } & \multicolumn{2}{c}{ GR $_{\text {50 }}(\mathbf{1 4}$ DAT $)$} & R/S \\
\cline { 2 - 3 } & Resistente & Suscetível & \\
\hline Chlorimuron - ethyl & 6,8 & 0,15 & 45,30 \\
Nicosulfuron & 23,54 & 0,13 & 181,08 \\
Imazethapyr & 2,45 & 0,1 & 24,55 \\
\hline
\end{tabular}




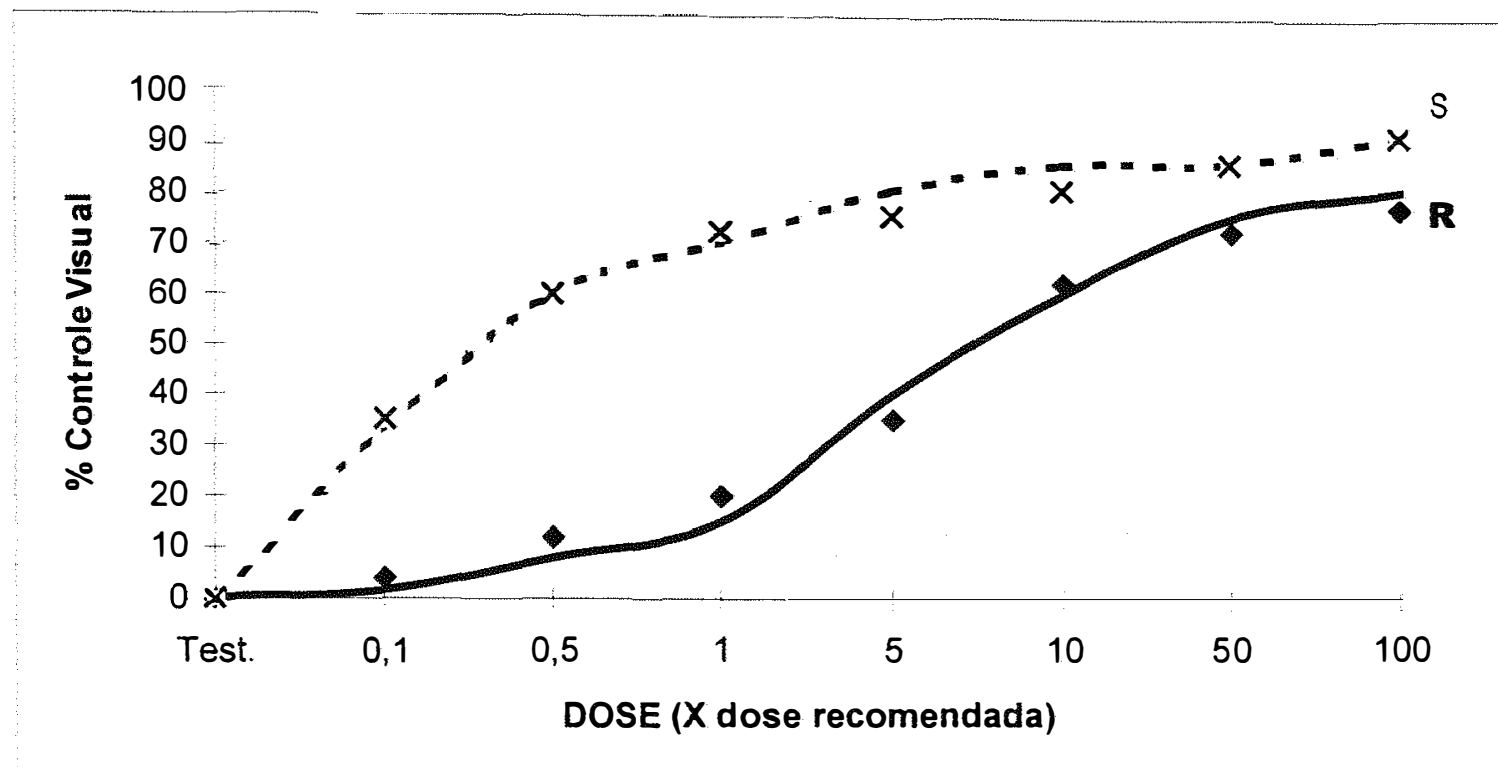

Figura 19 - Curvas de dose-resposta da porcentagem de controle dos biotipos resistentes e suscetíveis de Amaranthus quitensis aos 7DAT com chlorimuron-ethyl, segundo o modelo hiperbólico.

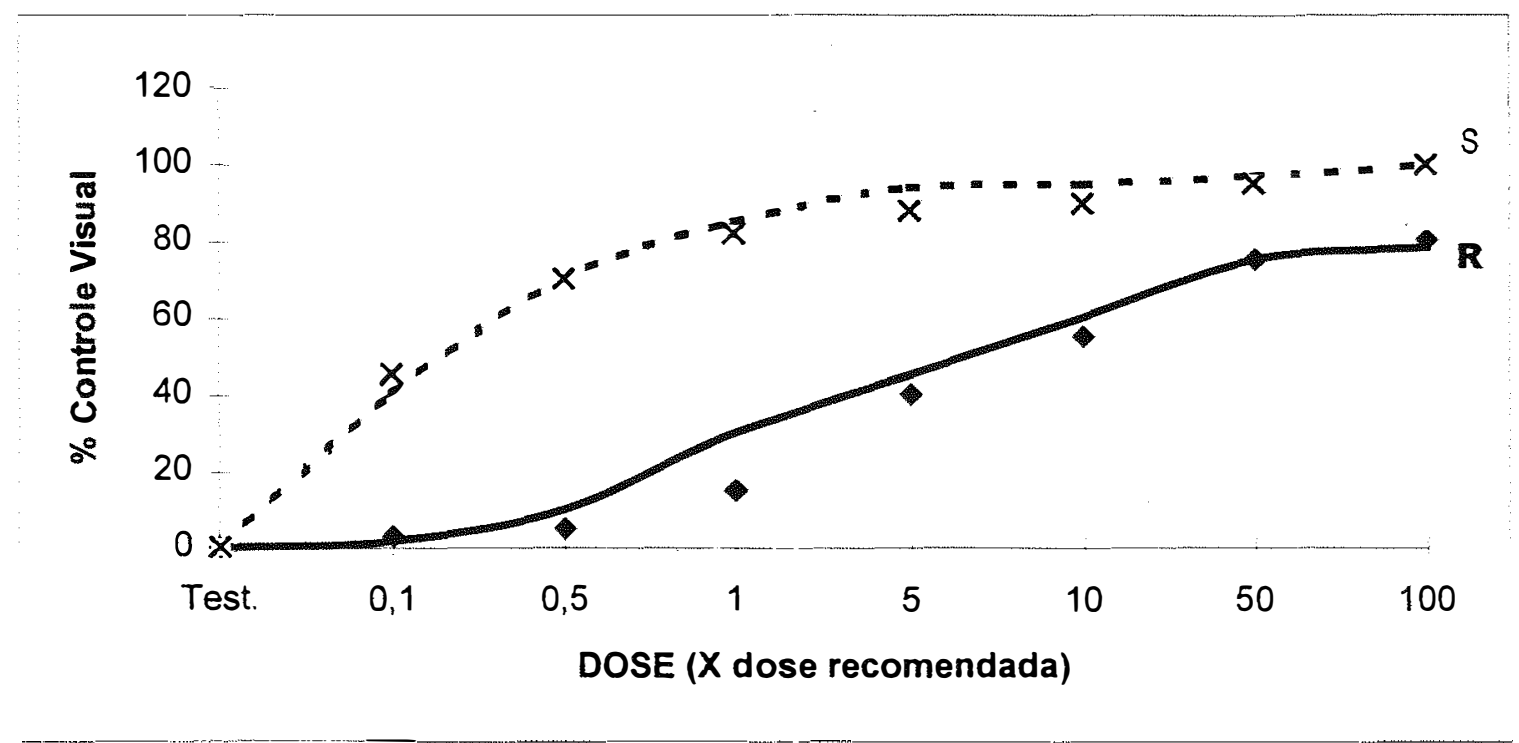

Figura 20 - Curvas de dose-resposta da porcentagem de controle dos biotipos resistentes e suscetíveis de Amaranthus quitensis aos 14 DAT com chlorimuron-ethyl, segundo o modelo hiperbólico. 


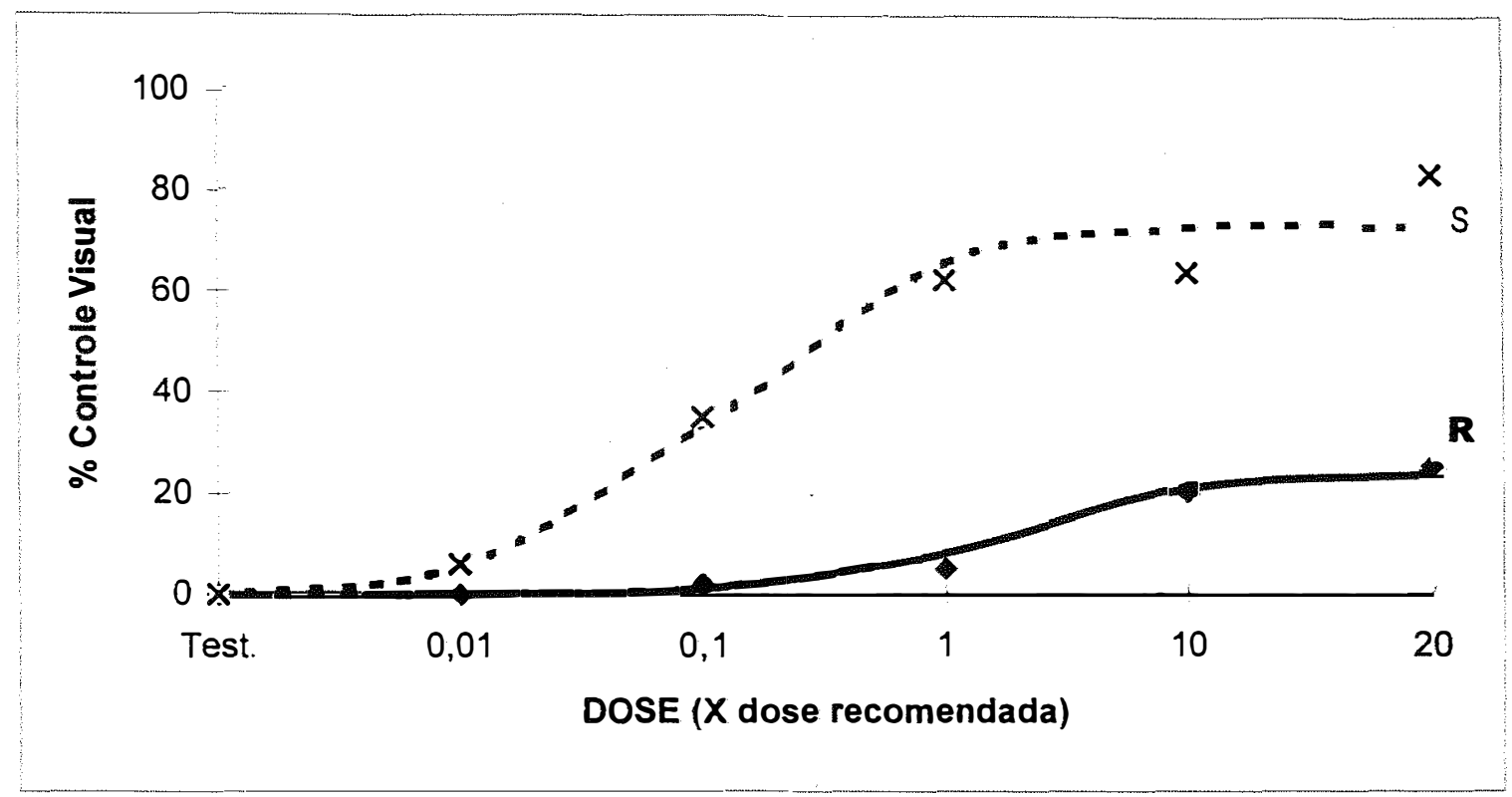

Figura 21 - Curvas de dose-resposta da porcentagem de controle dos biotipos resistentes e suscetíveis de Amaranthus quitensis aos 7 DAT com nicosulfuron, segundo modelo hiperbólico.

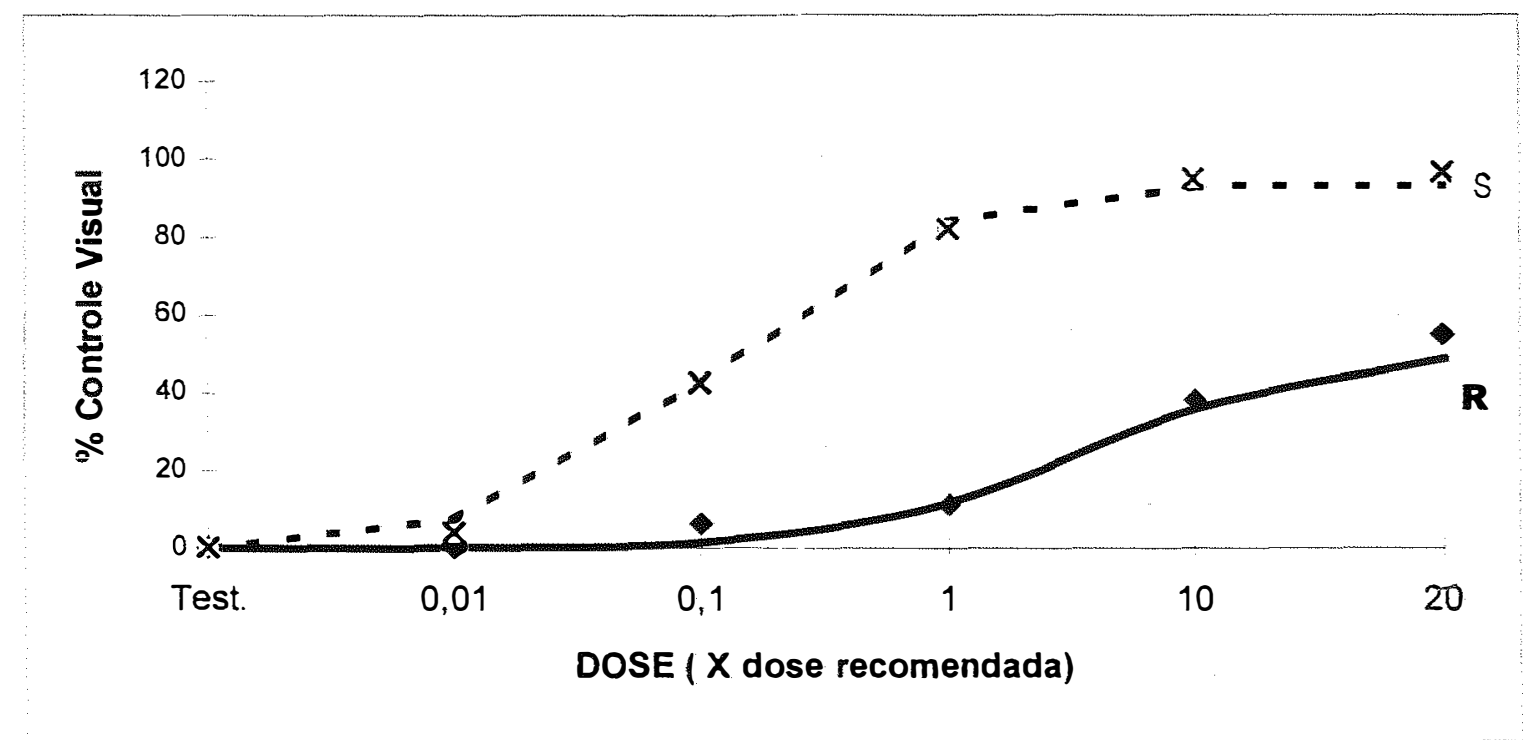

Figura 22 - Curvas de dose-resposta da porcentagem de controle dos biotipos resistentes e suscetíveis de Amaranthus quitensis aos 14 DAT com nicosulfuron, segundo modelo hiperbólico. 


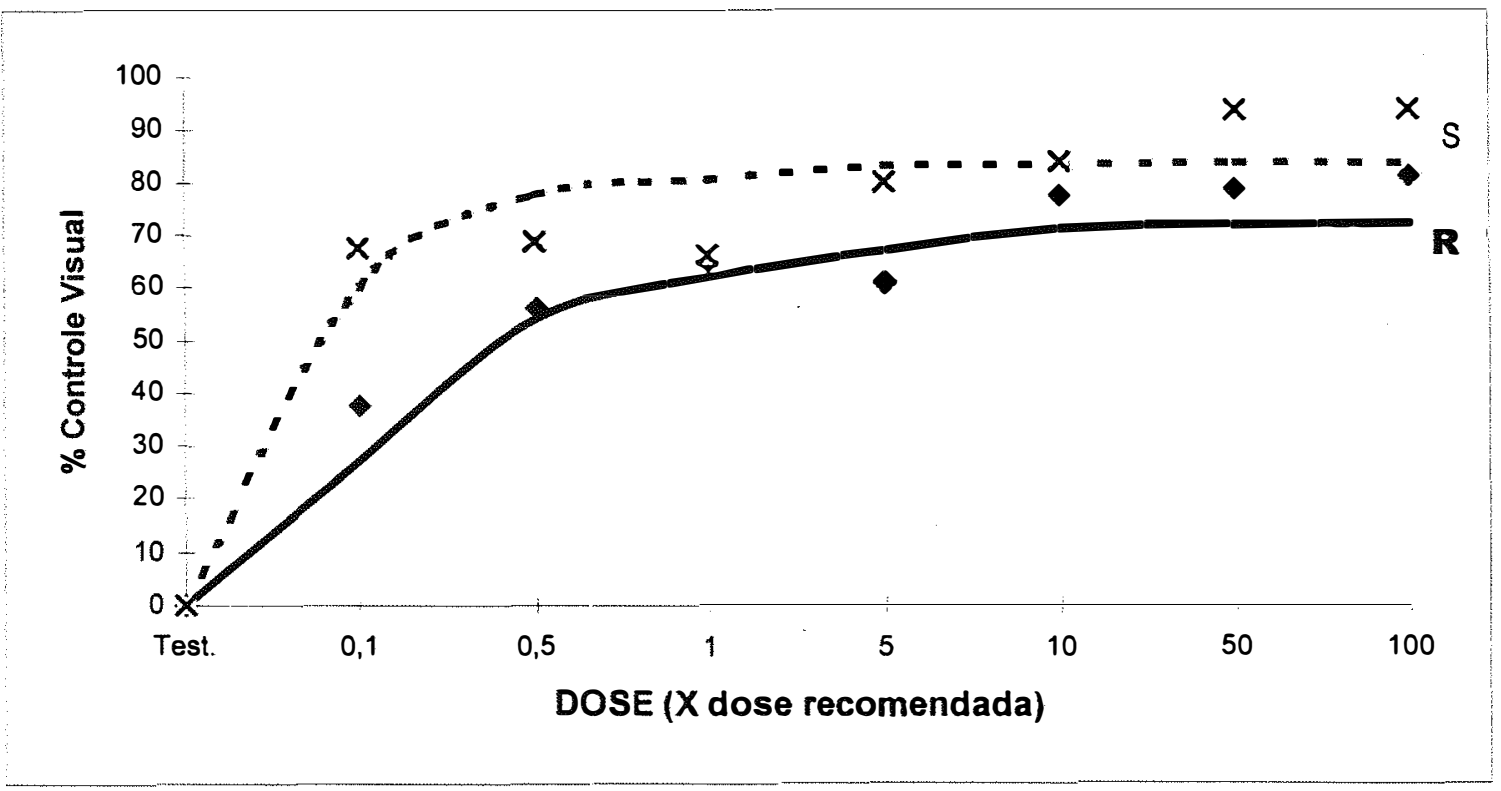

Figura 23 - Curvas de dose-resposta da porcentagem de controle, dos biotipos resistentes e suscetíveis de $A$. quitensis aos 7 DAT com imazethapyr, segundo o modelo hiperbólico.

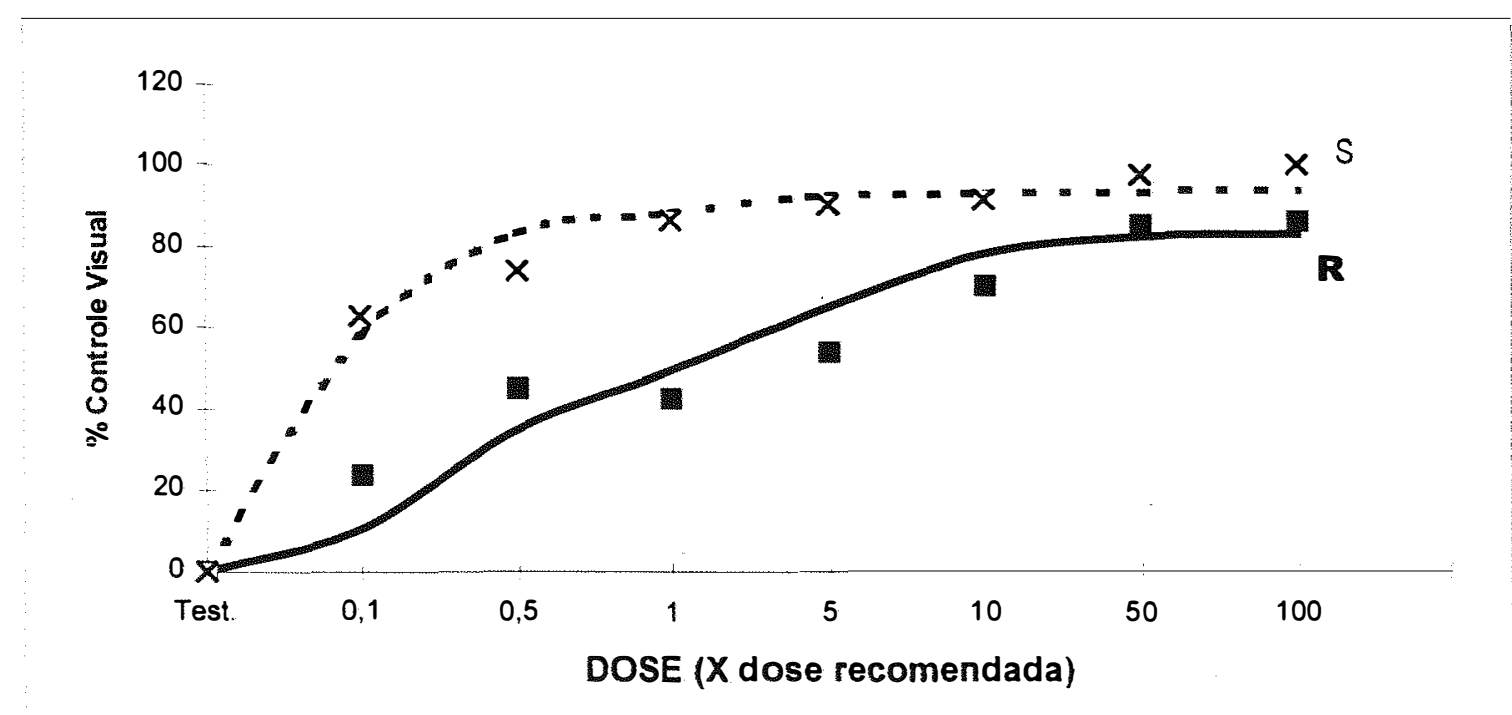

Figura 24 - Curvas de dose-resposta da porcentagem de controle, dos biotipos resistentes e suscetíveis de A. quitensis aos $14 \mathrm{DAT}$ com imazethapyr, segundo modelo hiperbólico. 


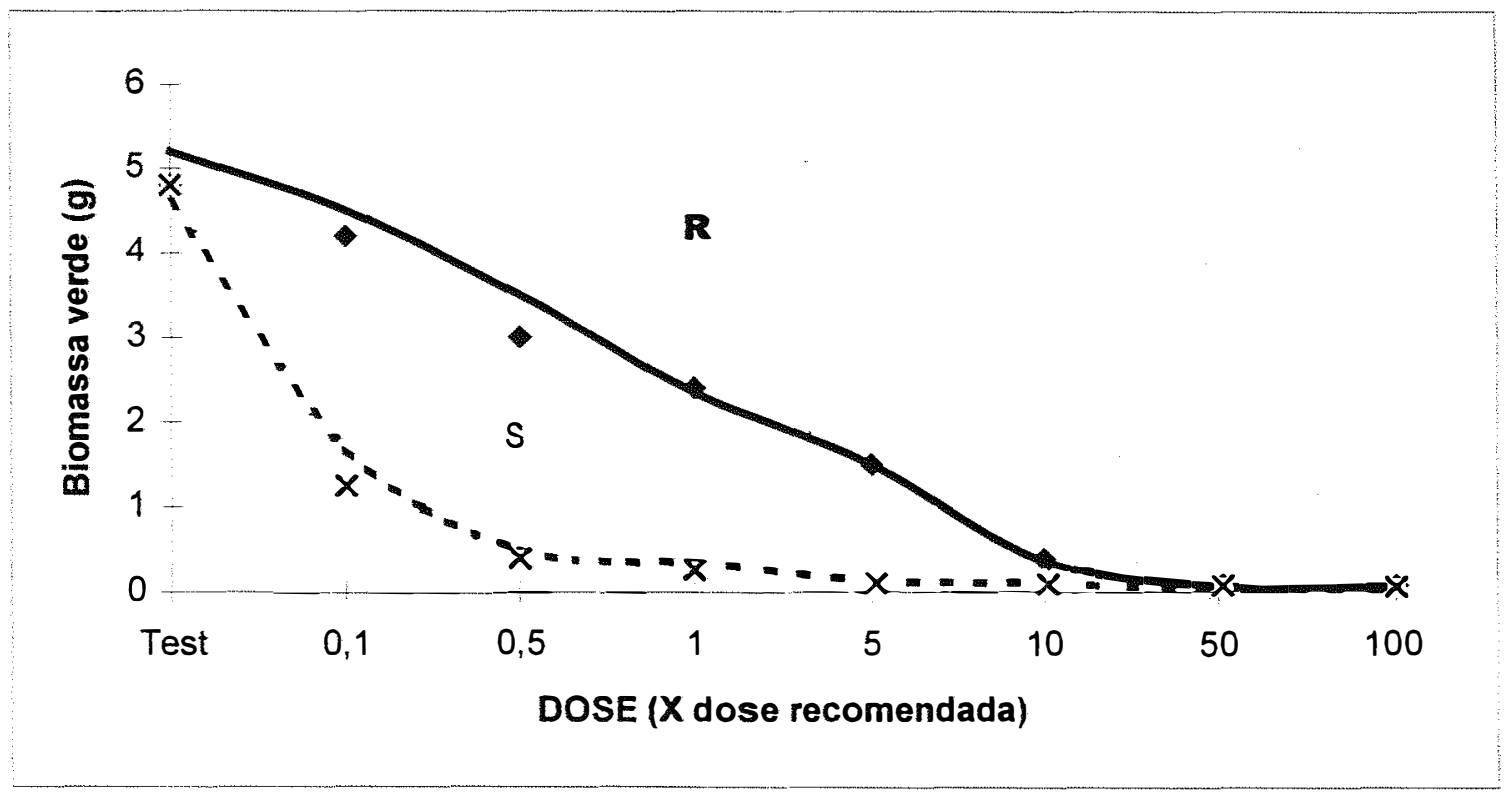

Figura 25 - Curvas de dose-resposta da produção de biomassa verde pelos biotipos resistentes e suscetíveis de Amaranthus quitensis, após tratamento com chlorimuron-ethyl, segundo o modelo exponencial.

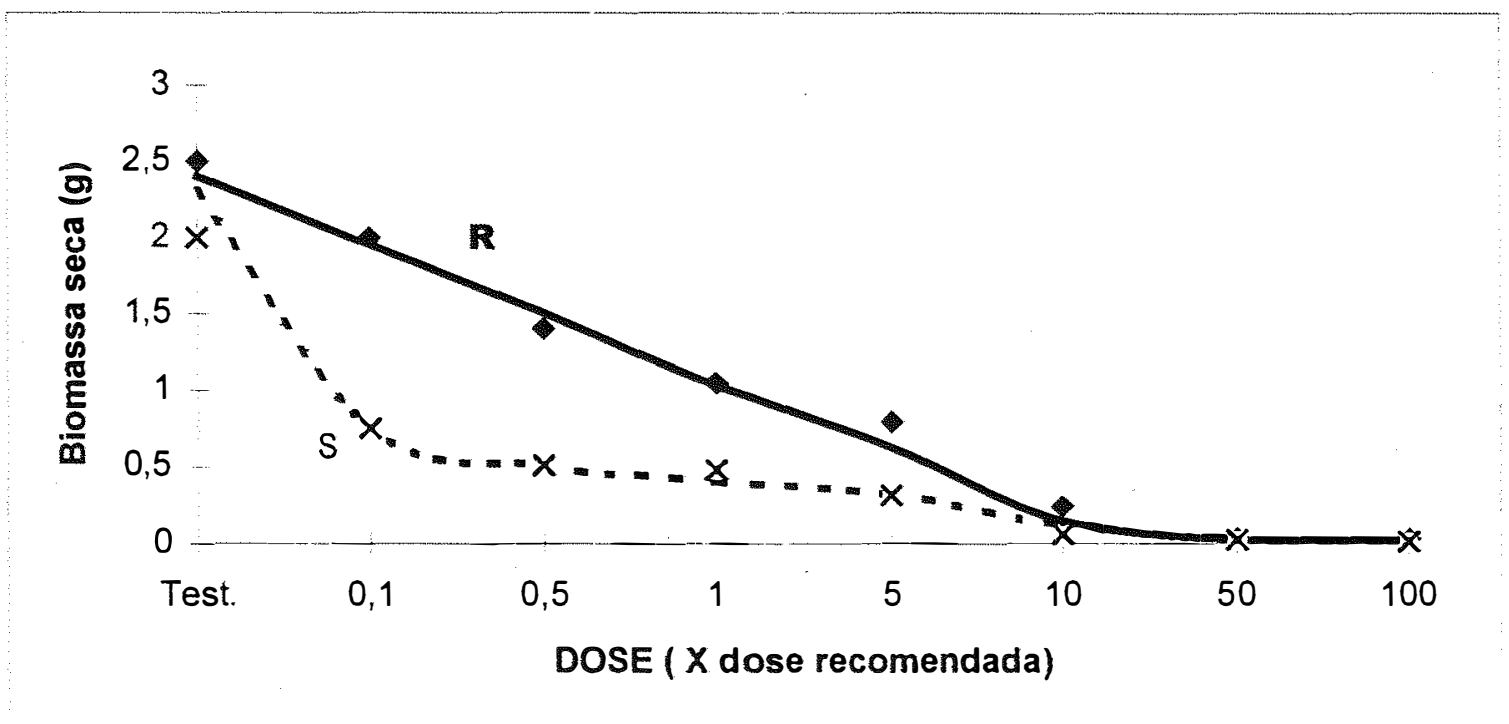

Figura 26 - Curvas de dose-resposta da produção de biomassa seca pelos biotipos resistentes e suscetíveis de Amaranthus quitensis, após tratamento com chlorimuron-ethyl, segundo modelo exponencial. 


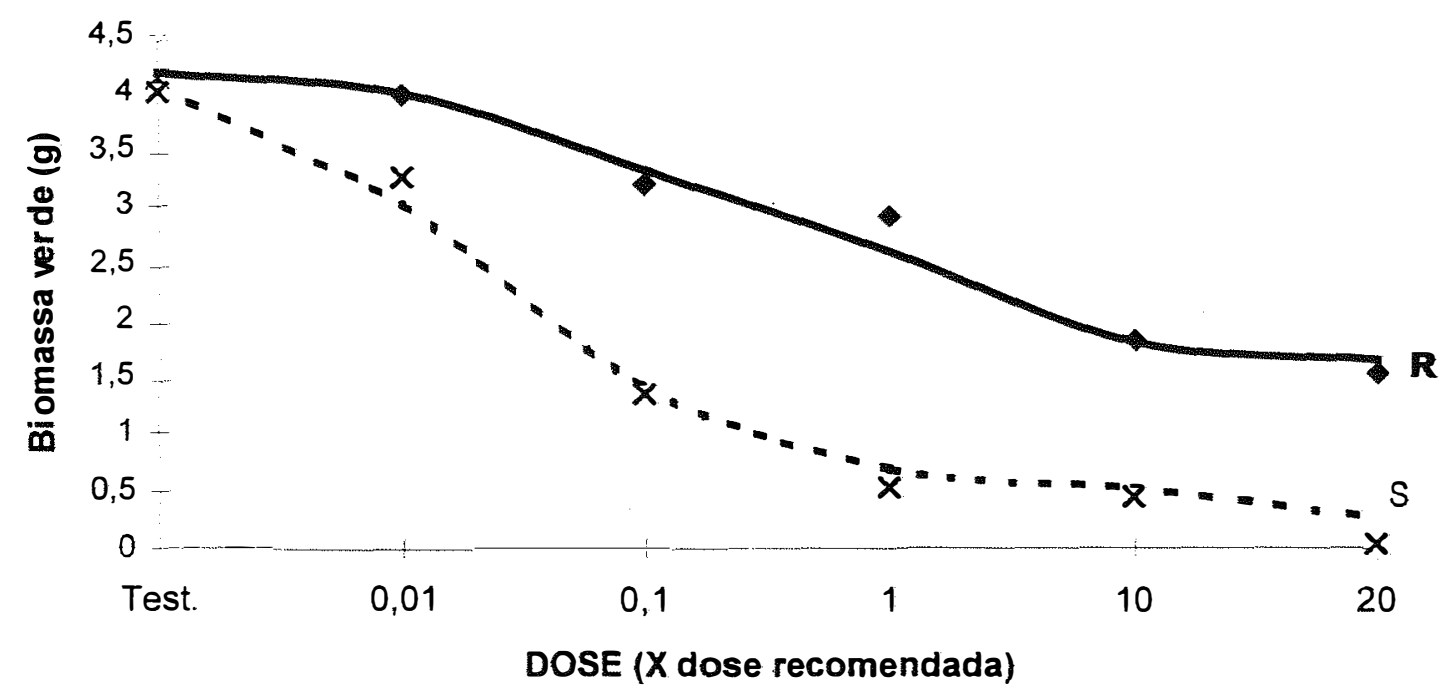

Figura 27 - Curvas de dose-resposta da produção de biomassa verde, pelos biotipos resistentes e suscetíveis de A. quitensis, após tratamento com nicosulfuron, segundo modelo exponencial.

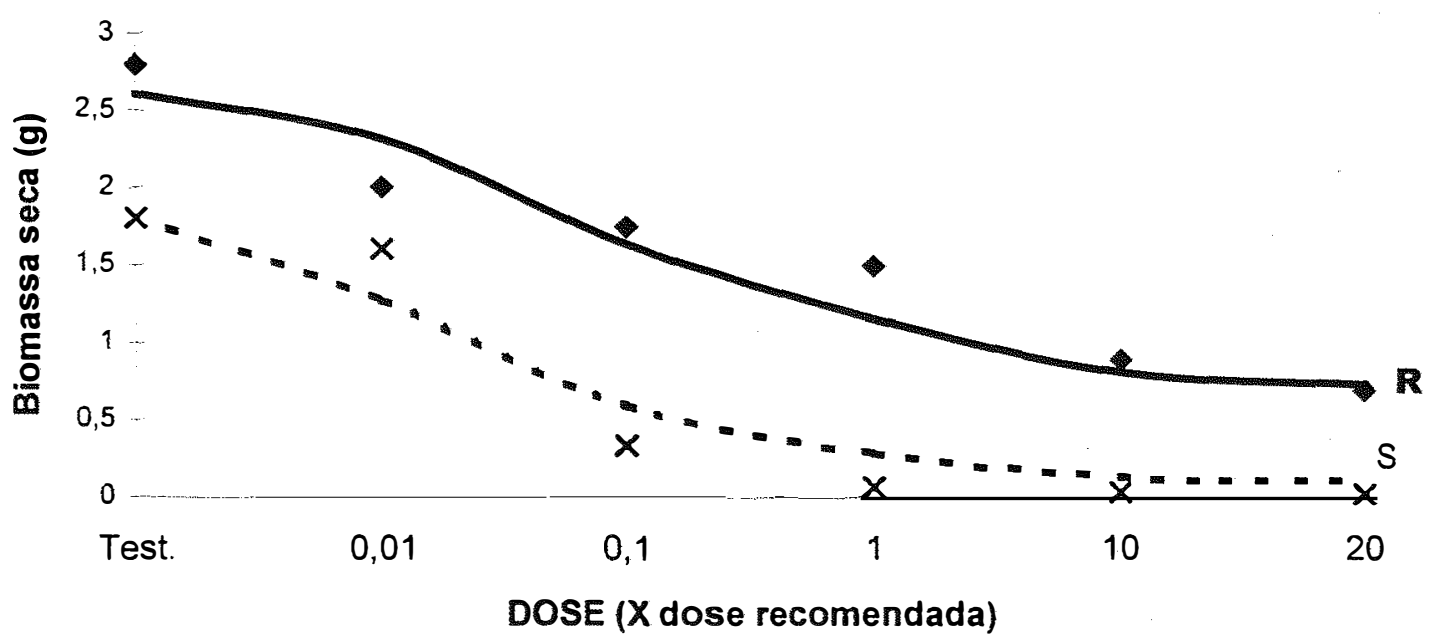

Figura 28 - Curvas de dose-resposta da produção de biomassa seca, pelos biotipos resistentes e suscetíveis de $A$. quitensis, após tratamento com nicosulfuron, segundo modelo exponencial. 


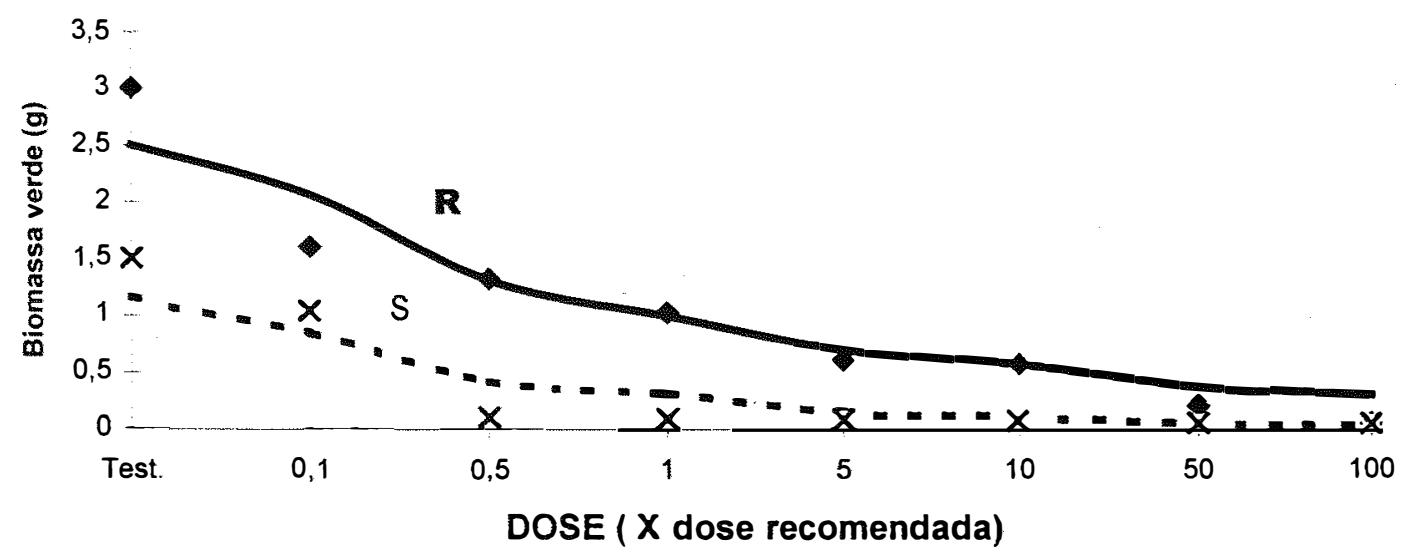

Figura 29 - Curvas de dose-resposta da produção de biomassa verde pelos biotipos resistentes e suscetíveis de $A$. quitensis, após tratamento com imazethapyr, segundo modelo exponencial.

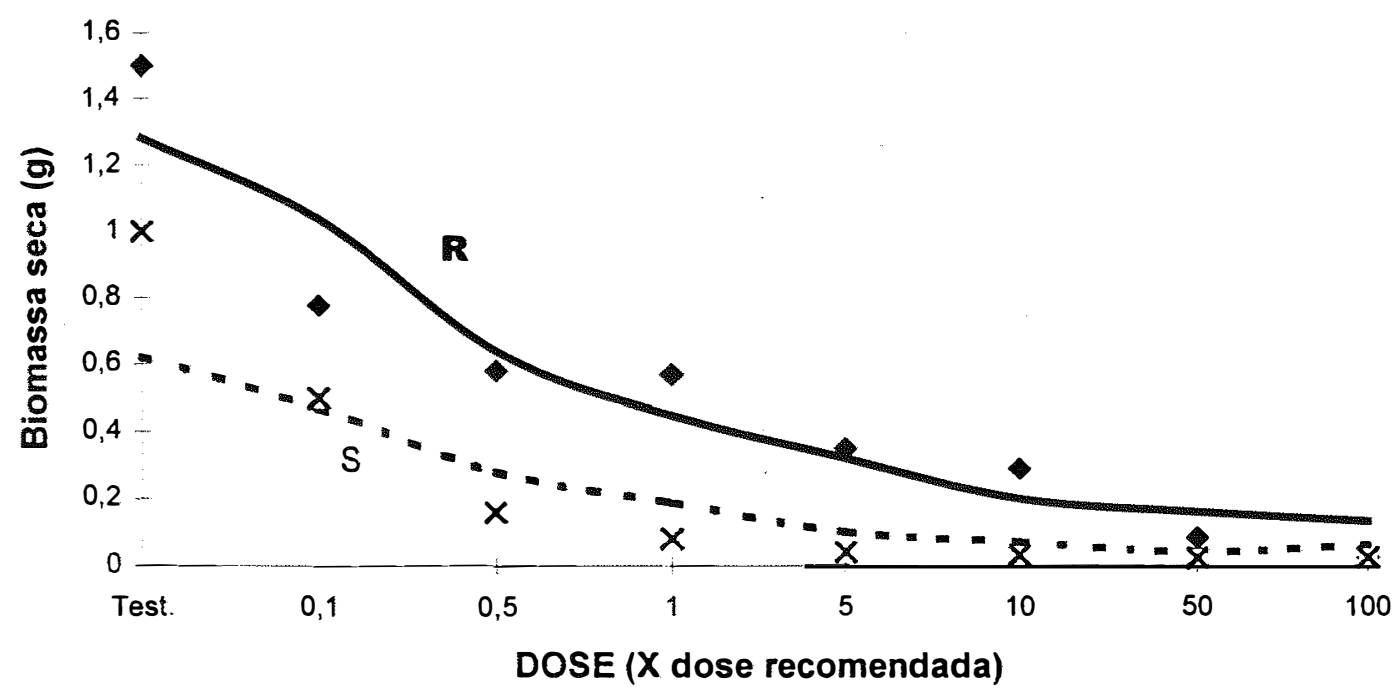

Figura 30 - Curvas de dose-resposta da produção de biomassa seca pelos biotipos resistentes e suscetíveis de A. quitensis, após tratamento com imazethapyr, segundo modelo exponencial. 
No caso dos herbicidas inibidores da ALS, a resistência de plantas daninhas ocorre devido a mutação nesta enzima, que a torna insensível à ação dos herbicidas. Entretanto, estas mutações podem ocorrer em diferentes locais do gene codificador da ALS, este fato, provavelmente é responsável pelos graus variáveis de insensibilidade a sulfoniluréias e imidazolinonas.

\subsection{Sequenciamento da região de domínio A do gene que confere resistência aos herbicidas inibidores da ALS em Amaranth us quitensis}

\subsubsection{Amplificação do gen codifica a ALS}

Os segmentos de DNA foram obtidos a partir de várias plantas de Amaranthus quitensis através de PCR, ou seja, método "in vitro" de sequências específicas de DNA, utilizando dois oligonucleotídeos (primers) que hibridizam fitas opostas e replicam, por intermédio de enzima polimerase e um mix de dNTPs, a região de interesse do DNA alvo.

Uma repetida série de 35 ciclos envolvendo denaturação por temperatura $\left(94^{\circ} \mathrm{C}\right)$, anelamento de primers $\left(72^{\circ} \mathrm{C}\right)$ e extensão destes pela DNA polimerase $\left(55^{\circ} \mathrm{C}\right)$, resultaram em acúmulo exponencial de fragmento específico, cujo sucesso da separação foi visto em gel de agarose 0,8\%. A partir de então, foi possível purificar todos os fragmentos obtidos com kit Qiaex e clonados em vetor pUC18 (Kit Sure clone) antes de serem sequenciados.

A partir da utilização dos "primers" degenerados (ALS-P1 a P6), foi obtido maior frequência de presença de amplificação de segmentos de DNA. Após várias tentativas foi possível obter amplificações nas seguintes combinações de primers: 
P2-P4: Amaranthus quitensis Resistente e Suscetível

P1-P5: Amaranthus quitensis Resistente e Suscetível

P1-P6: Amaranthus quitensis Suscetível

A combinação P2-P4 por apresentar uma banda com homologia específica foi clonado em vetor pUC18 (Kit Sure clone). Na foto abaixo pode-se ver: A- marcador de 100 pb- 2072 pb; B- marcador lambda de 2300 pb; 1- fragmento de Amaranthus quitensis resistente e 2 fragmento de Amaranthus quitensis suscetível.

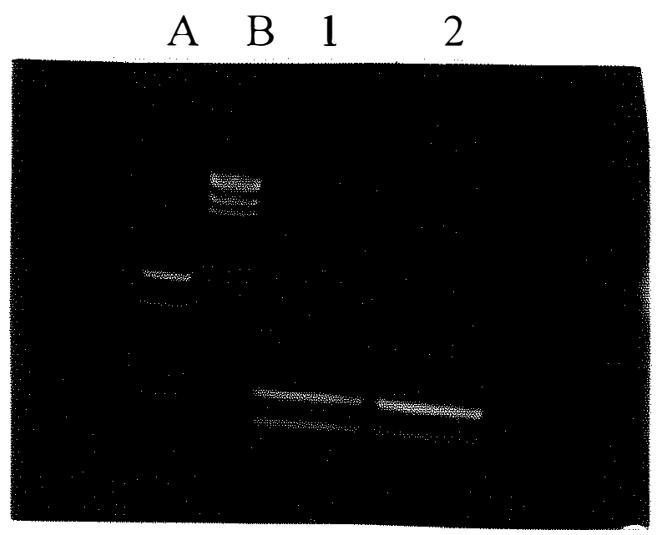

\subsubsection{Sequenciamento de DNA}

Após a clonagem dos segmentos no sítio de restrição Smal do vetor pUC18, colônias transformadas foram analisadas para a presença do fragmento de inserção utilizando-se enzimas de restrição SstI e HindIII. Quando obtivemos clones apresentando o fragmento de tamanho correspondente ao produto de $\mathrm{PCR}$, o clone foi sequenciado e os resultados estão apresentados a seguir. Para Amaranthus quitensis, foi mostrado a similaridade com o gene de Amaranthus rudis já sequenciado. 
Através da análise de BLAST-N (similaridade de nucleotídeo), Altschul el al (1997), utilizando para isso as informações contidas no site da internet NCBI (http://www.Ncbi.nlm.nih.gov) foi observado que A. quitensis (R e S) apresentam alinhamento com sequências de nucleotídeos do gene ALS.

Amaranthus quitensis apresentaram E-value de 0.0 com Amaranthus sp como esperado, e-109 para Bassia scoparia, 7e-48 para Arabidopsis thaliana, 3e-28 Xanthium sp 2e-26 Brassica napus, 3e-19 para $G$. hirsutum e, le-18 para $N$. tabacum.

A. rudis GGT GGG GTT TTC GCT GCT GAA GGC TAC GCT CGT S-A

S-A

S-A

S- A GGG

S- A GGG

R-A GGT .

$\mathrm{R}-\mathrm{A}$

$\mathrm{R}-\mathrm{A}$

$\mathrm{R}-\mathrm{A}$

R-A GGG -

A. rudis GCT ACT GGA CGT GTT GGA GTT TGT ATT GCC ACT S-A - - - - - CGC S-A S-A 


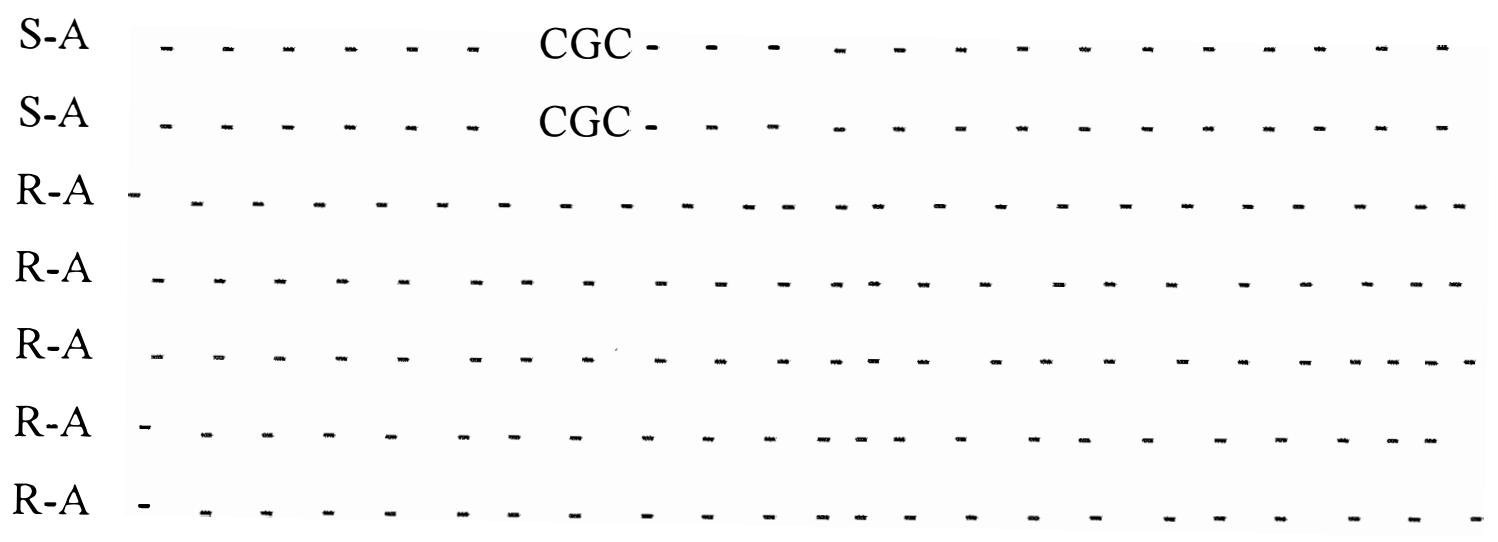

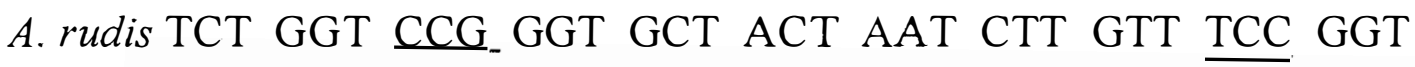
$\mathrm{S}-\mathrm{A}$ - - - - CCA - - - - - - - -

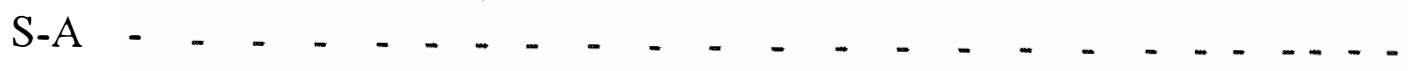
S-A - - - - - - - - - - - _ - - - S-A - - - - - - - - - - - - - - - - S-A - - - - - - - _ - - _ - - - - -

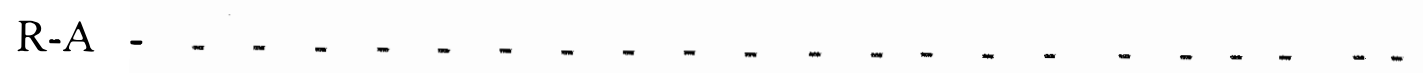

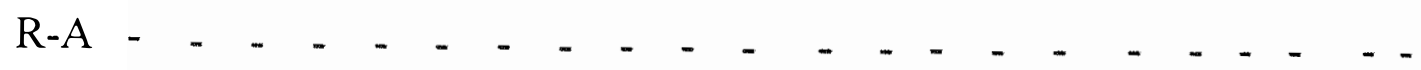

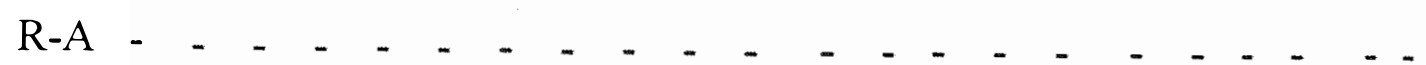
R-A - - - - TCA - - - _ - - - - - - . R-A - - - - TCA- - - - - - - - - - - - - -

A. rudis ITT GCT GAT GCA CTT CTT GAC TCA GTC CCG CTT

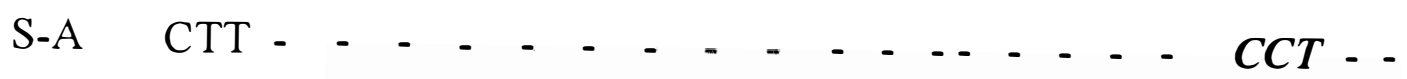
S-A CTT - $\ldots+\ldots \ldots \ldots+\ldots$

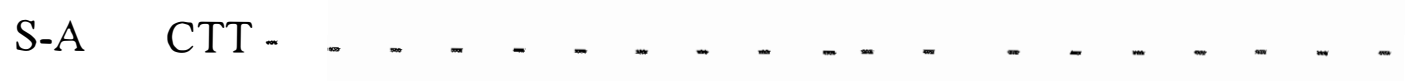

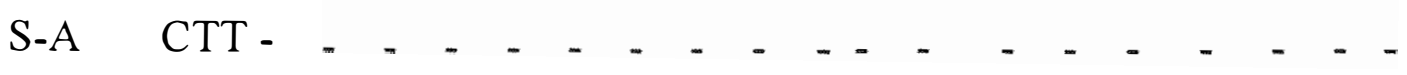




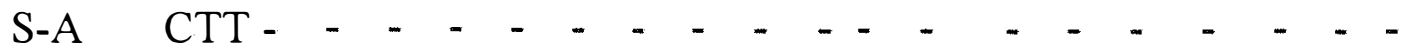

$\mathrm{R}-\mathrm{A} \quad-\quad--_{-}--_{-}--_{-}--_{-}^{-}-$

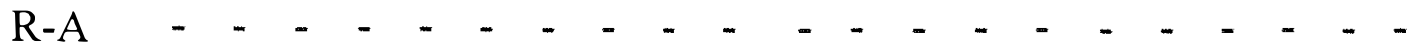

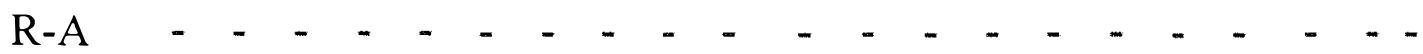

R-A $\quad-\quad-\ldots+\ldots$

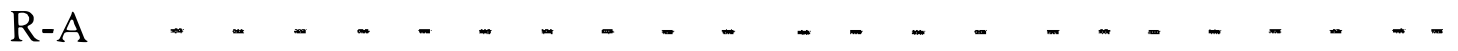

\section{Domínio A}

A. rudis GTC \{ GCC ATT ACT GGG CAA GTT $\underline{\text { CCT }}$ CGG CGT ATG

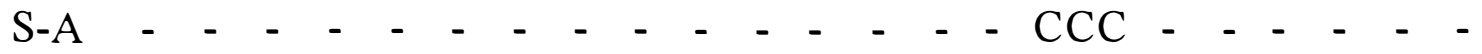

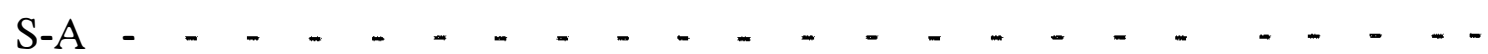
S-A - - - - - - - - - - - - - - - -

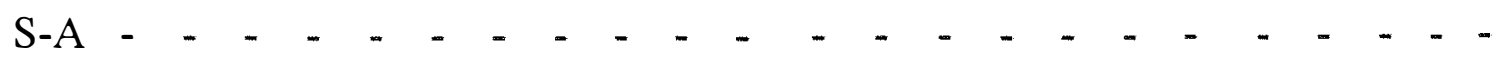
S-A - - - - - - - - - - - - - - -

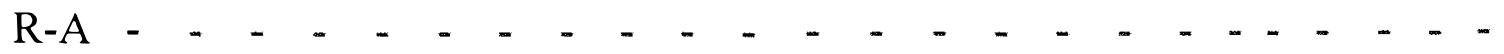
R-A - - - - - - - - - - - - - - R-A - - - - - - - - - - - - - - - - -

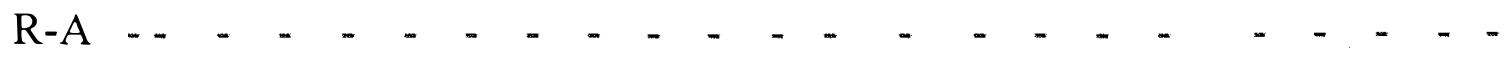
R-A - - - - - - - - - - - - - - - - - - -

A. rudis ATT GGT ACT GAT GCT\} TTT CAA GAG $\underline{\text { ACA CCT ATA }}$

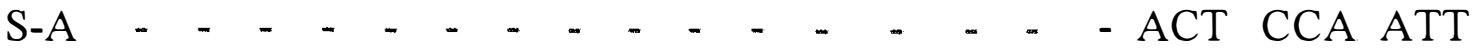

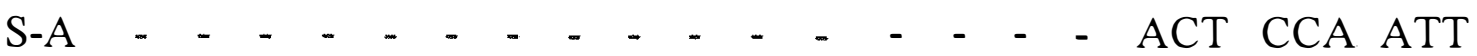
S-A - $-\ldots \ldots \ldots$ - $\ldots+\ldots$ ACT CCA ATT S-A - 


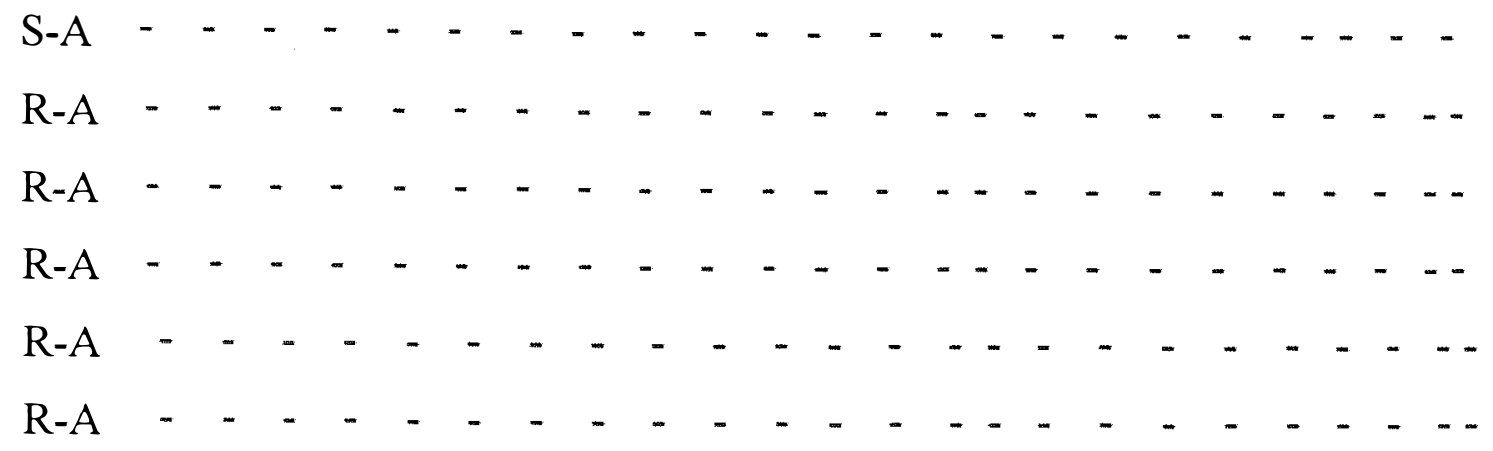

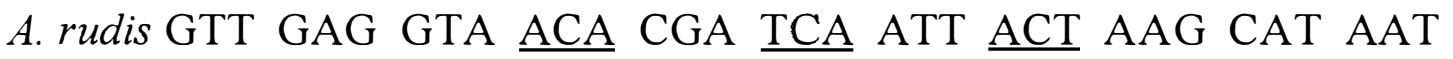
$\mathrm{S}-\mathrm{A}$ - - - - - ACT - - TCC - - ACC - - - -

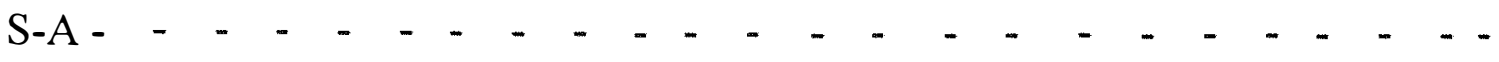
S-A - - - - - - - - - - - - - - - - S-A - - - - - - - - - - - - - - - S-A - - - - - - - - - - - - - - - R-A - - - - - - - - - - - - - - R-A - - - - - - - - - - - - - - - R-A - - - - - - - - - - - - - - - - R-A - - - - - - - - - - - - - - - R-A - - - - - - - - - - - - - - - -

A. rudis TAT TTG GTG TTA GAT GTT GAG GAT $\underline{\text { ATC }}$ CCT AGA S-A - - - - - - - - - - - ATT - - S-A - - - - - - - - - - - - - - - S-A - - - - - - - - - - - - - - - S-A S-A - 


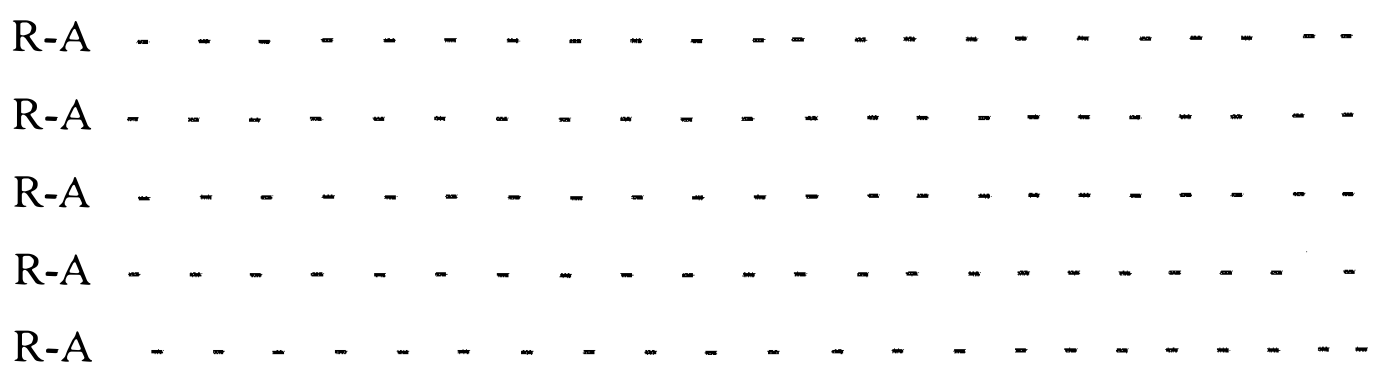

A. rudis ATT GTT AAG GAA GCT TTC TTT TTA GCT AAT TCT S-A - - - - - - GGA - - - - - - - - - - -

$\mathrm{S}-\mathrm{A}$ - - - - - GAA - - - - - - - - - S-A - - - - - GAA - - - - - - - - - - -

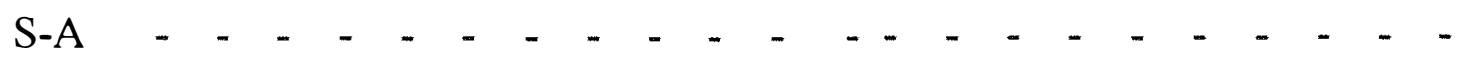
S-A - - - - - - - - - - - - - - - - - -

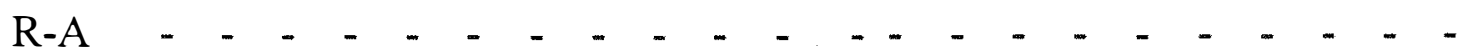
R-A - $-\quad-\quad-\quad-\quad-\quad-\quad-\quad-\quad-\quad-\quad-\quad-\quad-$ R-A - - - - - - - - - - - - - - - - -

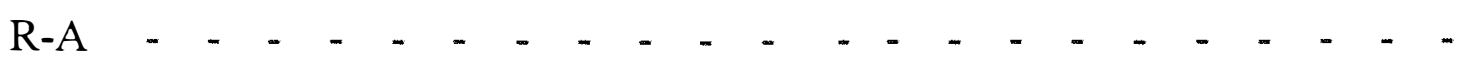
R-A - - - - - - - - - - - - - - - - - -

A. rudis GGT AGA CCT GGA CCT GTT TTG ATT GAT ATT CCT S-A - - - - - - - - - - - - - - - - S-A - - - - - - - - - - - - - - - - -

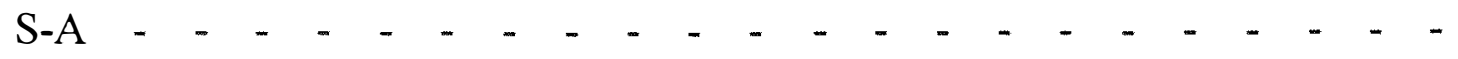
S-A - - - - - - - - - - - - - - - - - S-A - $-\quad-\quad-\quad-\quad-\quad-\quad-\quad-\quad-\quad-\quad-\quad-\quad-$ R-A - - - - - - - - - - - - - - - - - 
$\mathrm{R}-\mathrm{A}$

$\mathrm{R}-\mathrm{A}$

R-A

R-A

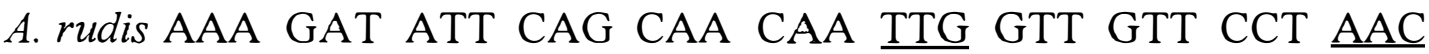

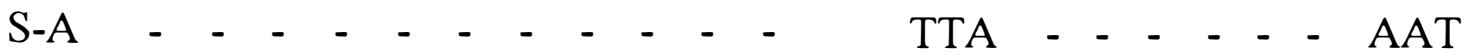
S-A - - - - - - - - - - - - - - - -

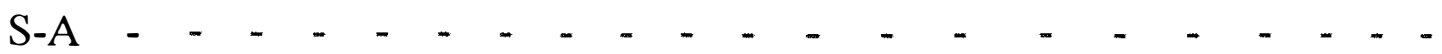

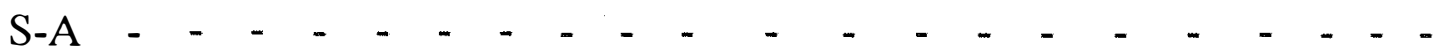

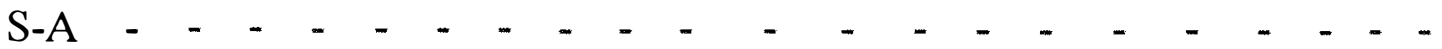
R-A - - - - - - - - - - - - - - - R-A - - - - - - - - - - - - - - - -

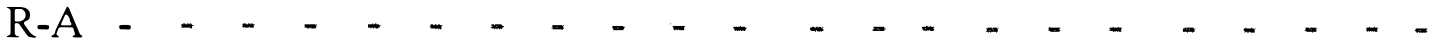
R-A $\mathrm{R}-\mathrm{A}$

A. rudis TGG GAA CAG CCC ATT AAA TTG GGT GGG TAT CTT S-A S-A

S-A S-A S-A - - - - - - - - - GGC - - - R-A $G G T$

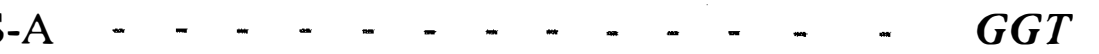
S-A - - - - - - - - - - GGT - - - S-A - - - - - - - - - $-G G C+\ldots$ R-A - - - - - - - - - $\quad G G T+-{ }_{-}-$ 


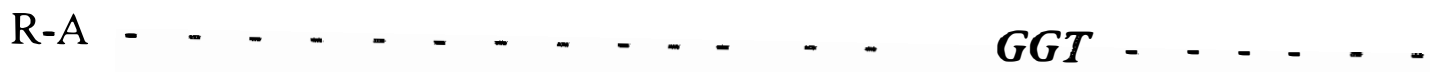
R-A - - - - - - - - - - - - - . - - R-A - - - - - - - - - - - - - - - - -

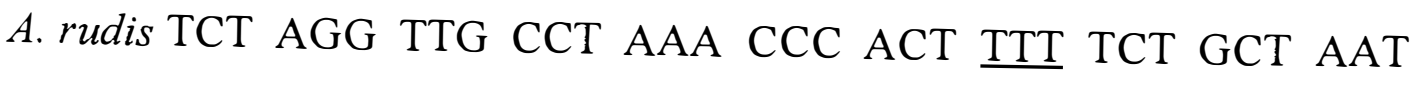

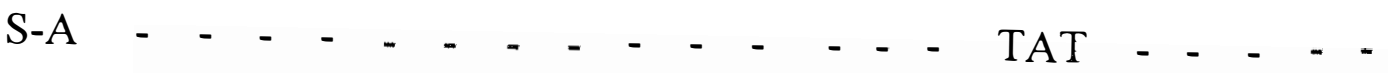
$\mathrm{S}-\mathrm{A}-{ }_{-}-{ }_{-}+\ldots-\ldots+\ldots$

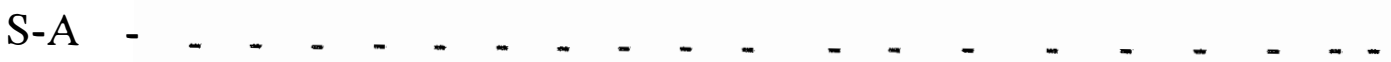
S-A S-A $\mathrm{R}-\mathrm{A}$

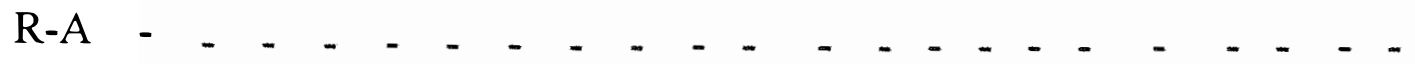

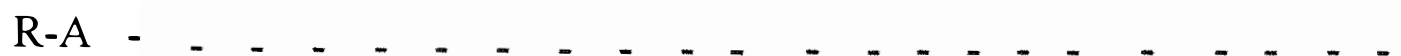
$\mathrm{R}-\mathrm{A}$ R-A

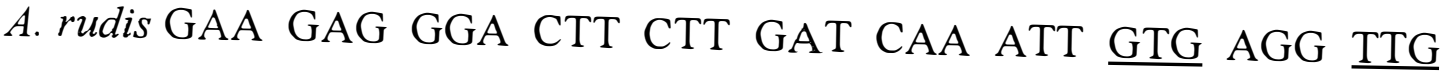
S-A - $-\quad-\quad-\quad-\quad-\quad-\quad-\quad-$ GTA - - TTA S-A - - - - - - - - - - - - - - - - S-A S-A S-A $\mathrm{R}=\mathrm{A}$ R-A R-A 
R-A

$\mathrm{R}-\mathrm{A}$

A. rudis GTG GGT GAG TCT AAG AGA CCT GTG CTG TAT ACT $\mathrm{S}-\mathrm{A}$

S-A

S-A

S-A

S-A

$\mathrm{R}-\mathrm{A}$

R-A

$\mathrm{R}-\mathrm{A}$

R-A

R-A

A. rudis GGA GGT GGG TGT TTG AAT TCT AGT GAA GAA TTA AGG S-A $G G A$

S-A

S-A $\quad \cdots G G A$

S-A

S-A

$G G A$ -

R-A

R-A

R-A

R-A - . 
R-A - - GGT -

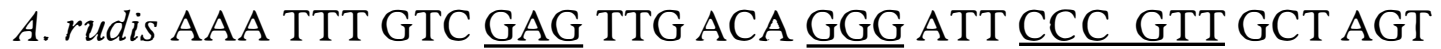
S-A - - . - GAA - - - GGT - CCGGTG - - S-A S-A S-A S-A R-A R-A R-A R-A $\mathrm{R}-\mathrm{A}$

(1028)

A. rudis ACT TTA ATG GGG TTG GGG GCT TTC CCT TGT ACT GAT S-A S-A S-A S-A S-A R-A R-A R-A R-A 
Foram sequenciadas cinco plantas de cada biotipo de $A$. quitensis. Pode-se observar que não houve mudança entre os biotipos na região de domínio $\mathrm{A}$, onde a mutação, na maior parte dos casos, ocasiona a resistência em plantas daninhas e plantas cultivadas aos herbicidas inibidores da ALS. Houve modificações em algumas regiões, como por exemplo, duas plantas do biotipo resistente apresentaram na posição 497, a sequência TCA (Serina), no lugar de CCA (Prolina) o que pode indicar que outras regiões além do domínio A podem sofrer mutações que podem confir resistência aos herbicidas inibidores da ALS. Guttieri et al, (1995), compararam uma região de 86 pares de base(pb) do gen da ALS entre 10 biotipos de Kochia scoparia resistentes ao chlorsulfuron e três biotipos suscetíveis. Verificaram que em sete das plantas resistentes houve um ponto de mutação na posição 173 no domínio A, onde prolina foi susbstituída por threonina, serina, arginina, leucina, glutamina e alanina. O mecanismo de resistência foi determinado para os biotipos resistentes que não apresentaram mutação no domínio $\mathrm{A}$; todos apresentaram resistência devido a insensibilidade da ALS, indicando que pelo menos uma mutação em regiões após o domínio A existe em Kochia scoparia. Do mesmo modo, as plantas resistentes da espécie Amaranthus quitensis, apresentaram enzima ALS insensível à ação dos herbicidas, ocorrendo portanto, mutações em regiões de nondomínio A.

A análise de várias plantas resistentes aos herbicidas inibidores da ALS, tem permitindo uma série de generalizações: substituições para Alanina $_{114}$ ou Serina ${ }_{649}$ resultaram em um alto nível de resistência aos herbicidas do grupo químico das imidazolinonas, mas pouca ou nenhuma resistência aos herbicidas do grupo químico das sulfuniluréias. Substituições para Prolina 189 ocasionam um nível alto de resistências as sulfuniluréias e pouca ou nenhuma resistência as imidazolinonas; substituições para Alanina $_{197}$ ocasionam uma moderanda resistência aos herbicidas 
dos dois grupos químicos citados e substituições para Triptofano ${ }_{570}$ ocasionam um alto nível de resistência a ambos grupos químicos. (Wright \& Penner, 1998). 


\section{CONCLUSÕES}

De acordo com os resultados obtidos, pode-se concluir que:

a) A população da planta daninha $B$. pilosa/B. subalternans infestante da cultura da soja em São Gabriel do Oeste- MS é constituída predominantemente de um biotipo resistente aos herbicidas inibidores da acetolactato sintase. Da mesma forma a população de Amaranthus quitensis proveniente da Argentina é resistente aos herbicidas inibidores da ALS.

b) Os biotipos de B. pilosa/ B. subalternans e A. quitensis estudados possuem resistência cruzada aos herbicidas inibidores da ALS pertencentes aos grupos químicos das sulfoniluréias e imidazolinonas.

c) Os biotipos estudados das duas espécies de plantas daninhas não possuem resistência múltipla aos herbicidas inibidores do fotossistema II (bentazon) e aos inibidores da PROTOX (lactofen e fomesafen), sendo estes herbicidas alternativos para prevenção e manejo da resistência aos herbicidas inibidores da ALS.

d) A resistência dos biotipos de B. pilosa/B. subalternans e A. quitensis aos herbicidas inibidores da ALS avaliados nesta pequisa é decorrente da insensibilidade da enzima ALS à estes herbicidas. 
e) A aplicação de bioensaio com inibidores da KARI constitui uma metodologia rápida de detecção da resistência causada por insensibilidade da enzima aos herbicidas inibidores da ALS.

f) As pequenas diferenças existentes entre as curvas de crescimento comparativa dos biotipos resistentes e suscetíveis aos herbicidas inibidores da ALS indicam que a característica de resistência não provoca efeitos pleitrópicos de menor adaptabilidade ecológica dos biotipos resistentes de B. pilosa/B. subalternans e A. quitensis.

g) Sequenciamento da região de Domínio A do gen da ALS, em biotipos resistentes e suscetíveis de A. quitensis não apresentou modificações, havendo, portanto, mutações em outras regiões além deste domínio, que confere resistência à esta planta daninha. 


\section{BIBLIOGRAFIA}

ALTSCHUL, SF.; MADDEN, T.L.; SCHAEFFER, A.A.; ZHANG, J.; ZHANG,. Z.; MILLER, W.; LIPMAN, D.J. "Grapped BLSAST and PSI-BLAST: a new generation of protein database search programs", Nucleic Acids Res, v. 25, p. 3389-3402, 1997

BERNASCONI, P.; WOOD WORTH, A.R.; ROSEN, B.A.; SUBRAMANIAN, M.V.; SIEHL, D.L. A naturally occurring point mutation confers broad range tolerance to herbicides that target acetolactate synthase. Journal of Biology and Chemistry, v. 270, n. 29, p. 17381-17385, 1995.

BOUTSALIS, P.; POWLES, S.B. Seedbank characteristics of herbicide-resistant and susceptible Sisymbrium orientale. Weed Research, v.38, n.5, p.389-395, 1998.

BRAIN, P.; COUSENS, R. An equation to describe dose response where there is stimulation of growth at low doses. Weed Research, v. 29, p.93-96, 1989.

CHRISTOFFOLETI, P.J. Growth competitive ability, and fitness of sulfonylurea resistant and susceptible Kochia scoparia. Fort Collins, 1993. 198p. Dissertation (Ph.D) Colorado State University. 
CHRISTOFFOLETI, P.J.; VICTORIA FILHO, R.; SILVA, C.B. Resistência de plantas daninhas aos herbicidas. Planta Daninha, v.12, n.1, p.13-20, 1994.

CHRISTOFFOLETI, P.J. VICTORIA FILHO, R.; MONQUEIRO, P.A. Resistência cruzada e herbicidas alternativos de controle de biotipos de $B$. pilosa resistentes aos herbicidas inibidores da ALS. In: XXI Congresso Brasileiro da Ciência das Plantas Daninhas, Caxambú, 1997. Resumos. Caxambú: SBPD, 1997. p64.

DYER, W.E.; CHEE, P.W.; FAY. P.K. Rapid germination of sulfonylurea resistant Kochia scoparia accessions is associated with elevated seed levels of branched chain aminoacids. Weed Science. v. 41, n.4 , p.18-22, 1993.

EBERLEIN, C.V.; GUTTIERI, M.J.; THILL，D.C.; BAERG，R.J. Altered acetolactate synthase activity in ALS - inhibitor resistant prickly lettuce (Lactuca serriola). Weed Science, v.45, n. 2, p. 212-217, 1997.

FOES, M.J.; LIU, L.; VIGUE, G.; STOLLER, E.W.; WAX, L.M.; TRANEL, P.J. A Kochia (Kochia scoparia) biotype resistant to triazine and ALS - inhibiting herbicides. Weed Science, v. 47, n. 1, p.20-27, 1999.

FACCINI, D.; NESENSHON, L. Dinamica de la poblacion de yuyo colorado (Amaranthus quitensis H.B.K) influencia de los tratamientos quimicos y mecanicos en cultivo de soya. Pesquisa Agropecuária Brasileira, v.29, n.1, p. 33-42, 1994. 
FOES, M.J.; LUI, L.; TRANEL, P.J.; WAX, L.M.; STOLLER, E.W. A biotype of common waterhemp (Amaranthus rudis) resistant to triazine and ALS herbicides. Weed Science, v. 46, n.5, p. 514-520, 1998.

GAZZIERO, D.P.; BRIGHENTI, A.M.; MACIEL, G. D.; CHRISTOFFOLETI, P.J.; ADEGAS, F.S.; VOLL, E. Resistência de amendoim-bravo aos herbicidas inibidores da enzima ALS. Planta Daninha, v. 16, n.2, p. 117125, 1998.

GERWICK, B.C.; MIRELES, L.C.; EILERS, R.J. Rapid diagnosis of ALS/AHAS inhibitor herbicide resistant weeds. Weed Technology, v.7, n.2, p.519-524, 1993.

GOULD, F. Comparisons between resistance management strategies for insects and weeds. Weed Technology, v.9, n.4, p. 830-839, 1995.

GURJEET, S.G.; COUSENS, R.D.; ALLAN, M.R. Germination, growth and development of herbicide resistant and susceptible populations of rigid ryegrass (Lolium rigidum). Weed Science, v. 44, n. 2, p.252-256, 1996.

GUTTIERI, M.J.; EBERLEIN, C.V.; MALLORY-SMITH, C.A.; THILL. D.C.; HOFFMAN, D.L. DNA Sequence variation in domain A of the acetolactate synthase genes of herbicide resistant and suscetible weed biotypes. Weed Science, v.40, n. 4, p. 670 - 676, 1992.

GRESSEL, J. e SEGEL, L.A. Modeling the effectiveness of herbicide rotation and mixtures strategies to delay or preclude resistance. Weed Technology, v. 4, p. 186-198, 1989. 
GUTTIERI, M.J., EBERLEIN, C.V., THILL, D.C. Diverse mutations in the synthase gene confer chlorsulfuron resistance in kochia (Kochia scoparia) biotypes. Weed Science, v.43, n. 2, p. 175-178, 1995.

GRESSEL, J.; SEGEL, L.A. The paucity of genetic adaptative resistance of plants to herbicides: possible biological reasons and implications. Journal of Theorical Biology, v.75, p.349-371, 1978.

HALL, L.M.; STROMME, K.M.; HORSMAN, G.P. Resistance to acetolactate synthase inhibitors and quinclorac in a biotype of false cleavers (Galium spurium). Weed Science, v. 46, n.4, p.390-396, 1998.

HEAP, I. International survey of herbicide resistant weeds. On line. Internet.www.weedscience.com. $6^{\text {th }}$ October. 1999

HEAP, I.M. The occurrence of herbicide-resistant weeds wordwide. Pesticide Science, v.51, p. 235-243, 1997.

HUTCHISON, J.M.; SHAPIRO, R.; SWEESTER, P.B. Metabolism of chlorsulfuron by tolerant broadleaves. Pesticide Biochemistry Physiology, v. 22, p.243-247, 1984.

HOLT, J.; LeBARON, H.M. Significance and distribution of herbicide resistance. Weed Technology, v.4, p. 141-149, 1990.

JEFFERS, G.M.; O’DONOVAN, J.T.; HALL, L.M. Wild mustard (Brassica kaber) resistance to ethametsulfuron but not to other herbicides. Weed Technology, v.10, n. 4, p.847-850, 1996. 
KEMP, M.S.; MOSSET, S.R.; THOMAS, T.T. Herbicide resistancer in Alopecurus myosyroides. In: GREEN, M.B.; LeBARON, H.L.; MOBERG, W.K. Managing resistance to agrochemicals: from fundamental research to practical strategies. Washington: American Chemical Society, 1990. p.376-393.

KISSMANN, K.G.; GROTH, D. Plantas infestantes e nocivas. Tomo II. São Paulo: Basf Brasileira S.A., v. 2, 798p, 1992.

KUDSK, P.; MATHIASSEN, S.K.; COTTERMAN, J.C. Sulfonylurea resistance in Stellaria media (L) Vill. Weed Research, v. 35, n.1, p. 19-24, 1995.

LORENZI, H.J. Plantas daninhas do Brasil. 4 Ed. Nova Odessa: Plantarum Ltda. 440p, 1994.

LOVELL, S.T.; WAX, L.M.; HORAK, M.J.; PETERSON, D.E. Imidazolinone and sulfonylurea resistance in a biotype of common waterhemp (Amaranthus rudis). Weed Science, v. 44, n. 4, p.789-794, 1996.

LOVELL, S.T.; WAX, L.M.; SIMPSON, D.M. 1996b. McGLAMERY, M. Using the in vivo acetolactate synthase assay for identifying herbicideresistant weeds. Weed Technology, v.10, p.936-942, 1996b.

MALLORY-SMITH, C.A.; THILL, D.C.; DIAL, M.J. Identification of sulfonylurea herbicide resistant prickly lettuce (Lactuca seriola). Weed Technology, v.4, p.787-790, 1990. 
MURRAY, M.G.; THOMPSON, W.F. Rapid isolation of high molecular weight plant DNA. Nucleic acids Research, v. 8, p. 4321-4325, 1980.

PONCHIO, J.A. Resistência de Bidens pilosa L. aos herbicidas inibidores da enzima acetolactato sintase. Piracicaba, 1996. 138p. Tese - Escola Superior de Agricultura Luiz de Queiroz- USP.

POWLES, S.B.; HOWAT, P.D. Herbicide resistance weeds in Australia. Weed Technology, v.4, p. 178-185, 1990.

POWLES, S.; HOLTUM, J. Herbicide resistance in plants: biology and biochemistry. New York: CRC Press, 1994.353p

PRIMINIANI, M.M.; COTTERMAN, J.C.; SAARI, L.L. Resistance of Kochia (Kochia scoparia) to sulfonylurea and imidazolinone herbicide. Weed Technology, v. 4, p.169-172, 1990.

RODRIGUES, B.N.; ALMEIDA, F.S. Guia de herbicidas. 3 Ed. Londrina: Edição dos Autores, 675p. 1995.

RUBIM, B. Herbicide resistance in weeds and crops, progress and prospects. In: CASELEY, J.C.; CUSSANS, G.W.; ATKIN,R.K. Herbicide resistance in weeds and crops. Oxford: Butterworth-heinemann Ed.; 1991. p. 387-414.

SAARI, L.L.; COTTERMAN, J.C.; SMITH, W.F.; PRIMIANI, M.M. Sulfonylurea resistance in common chickweed perennial ryegrass and russian thistle. Pesticide Biochemistry and Physiology, v. 42, n. 2, p.110-116, 1992. 
SANCHES, W.; ZANDONADE, D. Problemas e soluções no controle de plantas daninhas no MS e MT. In: I Simpósio sobre herbicidas e plantas daninhas, Dourados, 1997. Documentos Centro de Pesquisa Agropecuária do Oeste. v. 13, p.160-161.

SAWICKI, R.M. Defenition detection and documentation of inseticide resistance. In: FORD, M.G.; HOLLEMAN,D.W.; KHAMBAY. B.P.S.; SAVICKI, R.M. Combating resistance to xenobiotics biological and chemical approaches. Chichester: Ellis Horwood, 1987. p.105-117.

SEEFELDT, S.S.; GEALY, D.R.; BREWSTER, B.D.; FUERST, E.P. Cross resistance of several diclofop resistant will oat (Avena fatua) biotypes from the Willamette Valley of Oregon. Weed Science, v. 42, p.430-437, 1994.

SEEFELDT, S.S.; JENSEN, J.E., FUERST, P. Log-logistic analysis of herbicide dose response relationships. Weed Technology, v.9, n.2, p. 218-227, 1995.

SIMPSON, D.M.; STOLLER, E.W.; WAX, L.M. An in vivo acetolactate synthase assay. Weed Technology, v. 9, n.1, p.17-22, 1995.

STANNARD, M.E.; FAY, P.K. Selection of alfafa seedlings for tolerance to chlorsulfuron. In: Weed Science Society of America Meeting, 61. Proceedings. p.45. 1987.

SWEESTER, P.B.; SCHOW, G.S.; HUTCHISON, J.M. Metabolism of chlorsulfuron by plants: biological basis for selectivity of a new herbicide for cereals. Pesticide Biochemistry Physiology, v.17, p.18-23, 1982. 
TAMASHIRO, J.Y.; LEITÃO FILHO, H. de F. Observações sobre o ciclo de vida de Bidens pilosa L. (Compositae heliantheae). Hoehnea, v. 7, p. 27-40, 1978.

THILL, D.C.; MALLORY-SMITH, C.A.; SAARI, C.A.; COTTERMAN, L.L.; PRIMIANI, M.M.; SALADINI, J.L. Sulfonylurea herbicide resistance weeds: discovery, distribution, biology, mechanisms and manegement. In: CASELEY, J.C.; CUSSANS, G.W.; ATKIN, R.K. Herbicide resistance in weeds and crops. Oxford. Butterworth-Heinemann. p.145-164. 1991.

WARWICK, S.I. Herbicide resistance in weed plants: Physiology and population biology. Annual Review in Ecology and Systematic, v.22, p. 95-144, 1991

WESTERFELD, W.W. A colorimetric determination of blood acetoin. Journal Biolog. Chemistry, v.161, p.495-502, 1945.

WRIGHT, T.R.; PENNER, D. Classification of acetolactate synthase (ALS) resistance mutations. Weed Science. v.38, p. $11-15,1998$ 